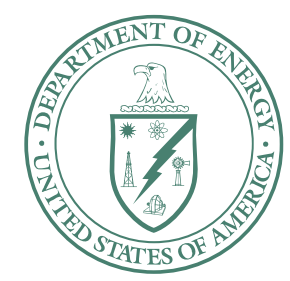

U.S. Department of Energy

Idaho Operations Office

\title{
Remedial Design/Remedial Action Work Plan for Operable Units 6-05 and 10-04, Phase III
}

September 2006 
DOE/NE-ID-11202

Revision 1

Project No. 23368

\section{Remedial Design/Remedial Action Work Plan for Operable Units 6-05 and 10-04, Phase III}

September 2006

Prepared for the 


\begin{abstract}
The remedial design/remedial action for Operable Unit 6-05 (Waste Area Group 6) and Operable Unit 10-04 (Waste Area Group 10)-collectively called Operable Unit 10-04 - has been divided into four phases. Phase I consists of developing and implementing institutional controls at Operable Unit 10-04 sites and developing and implementing Idaho National Laboratory-wide plans for both institutional controls and ecological monitoring. Phase II will remediate sites contaminated with trinitrotoluene and Royal Demolition Explosive. Phase III will remediate lead contamination at a gun range, and Phase IV will remediate hazards from unexploded ordnance.

This Phase III Remedial Design/Remedial Action Work Plan addresses the remediation of lead-contaminated soils found at the Security Training Facility (STF)-02 Gun Range located at the Idaho National Laboratory. Remediation of the STF-02 Gun Range will include excavating contaminated soils; physically separating copper and lead for recycling; returning separated soils below the remediation goal to the site; stabilizing contaminated soils, as required, and disposing of the separated soils that exceed the remediation goal; encapsulating and disposing of creosote-contaminated railroad ties and power poles; removing and disposing of the wooden building and asphalt pads found at the STF-02 Gun Range; sampling and analyzing soil to determine the excavation requirements; and when the remediation goals have been met, backfilling and contouring excavated areas, and revegetating the affected area.
\end{abstract}




\section{CONTENTS}

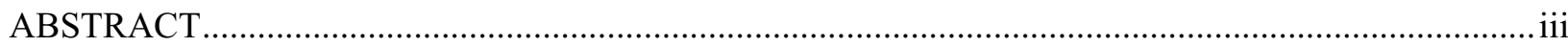

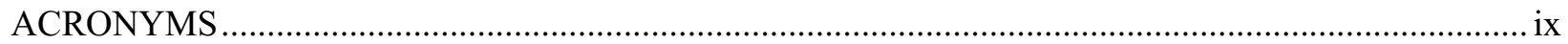

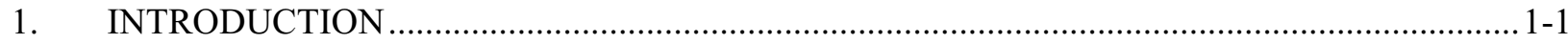

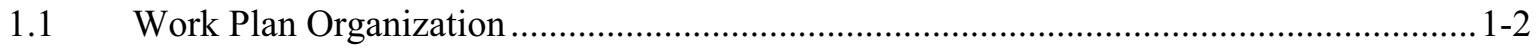

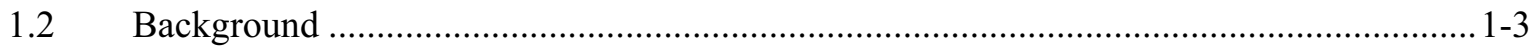

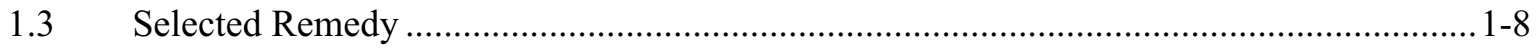

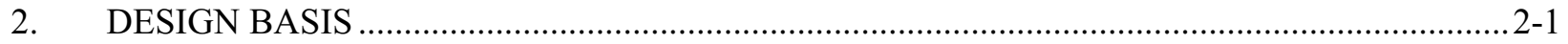

2.1 General Description of Project Components ............................................................. 2-1

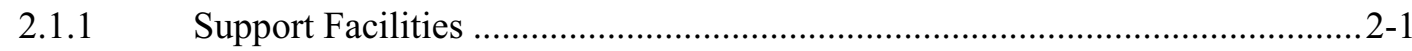

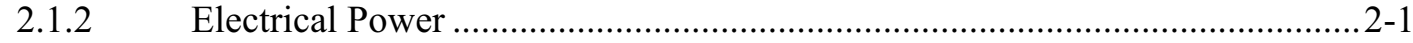

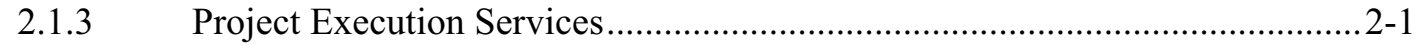

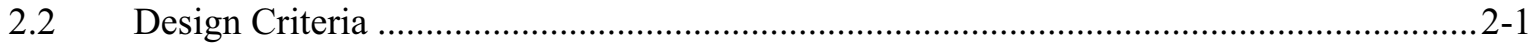

2.2.1 Management Control Procedures ............................................................. 2-1

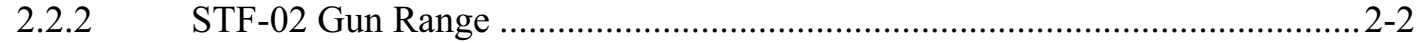

$2.3 \quad$ U.S. Department of Energy-Related Codes, Standards, and Documents .........................2-2

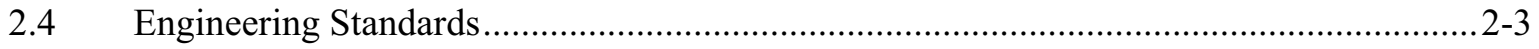

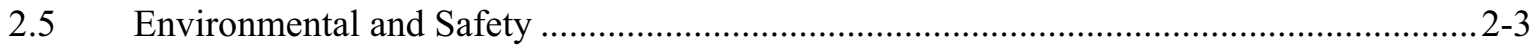

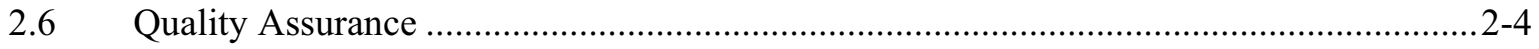

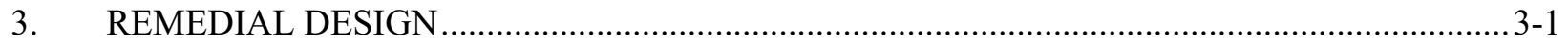

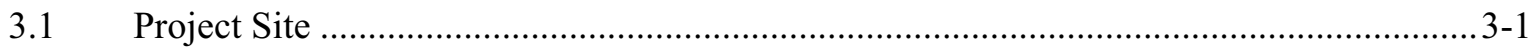

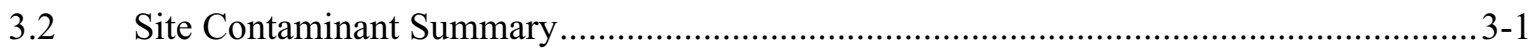

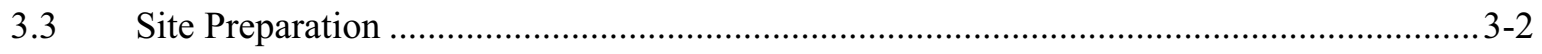

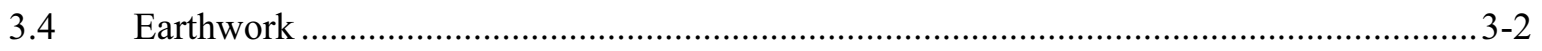

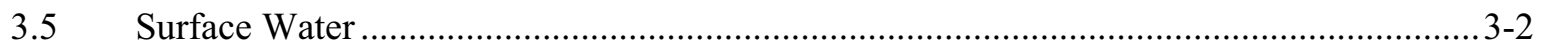

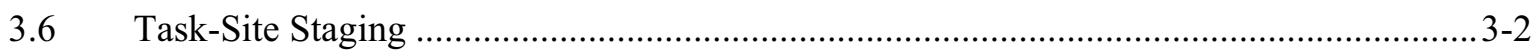

4. HUMAN HEALTH AND ENVIRONMENTAL COMPLIANCE ................................................ 4-1

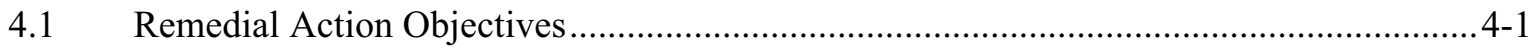

4.2 Applicable or Relevant and Appropriate Requirements ..............................................4-2 
5. REMEDIAL ACTION WORK PLAN ..............................................................................

5.1 Relevant Changes to the Scope of Work .................................................................. $5-1$

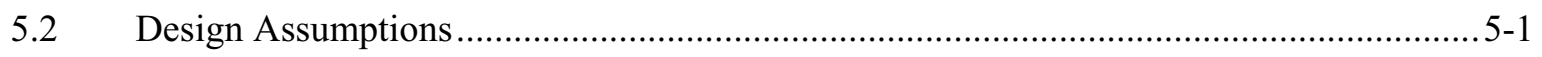

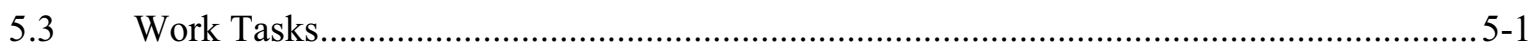

5.3.1 Premobilization ............................................................................. $5-2$

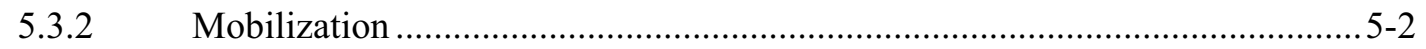

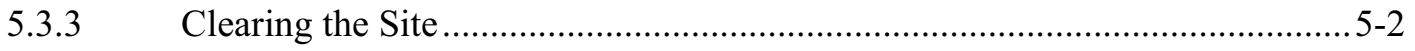

5.3.4 Soil Excavation and Consolidation ...................................................... $5-2$

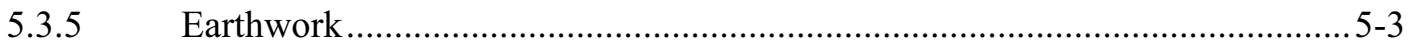

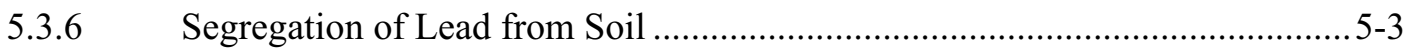

5.3.7 Borrow, Haul, and Stockpile .....................................................................

5.3.8 Contaminated Soil Hauling .....................................................................

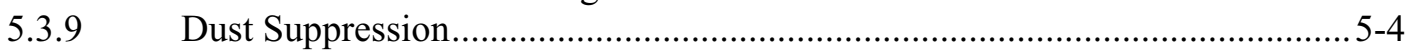

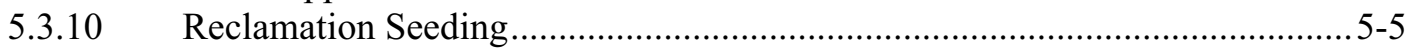

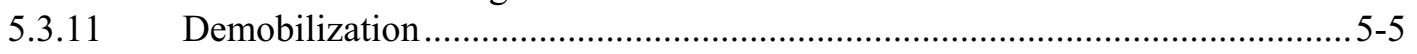

S.4 Summary of Site Activities ..........................................................................

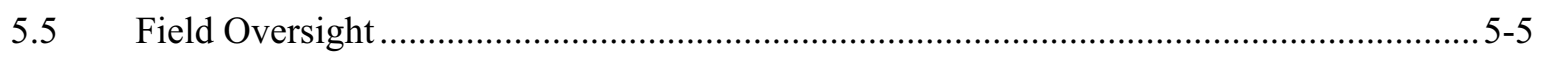

5.5.1 Protocol and Coordination of Field Oversight ............................................ 5-5

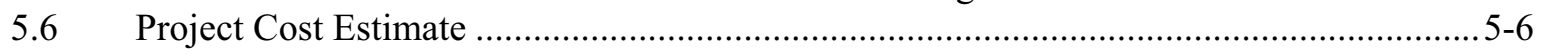

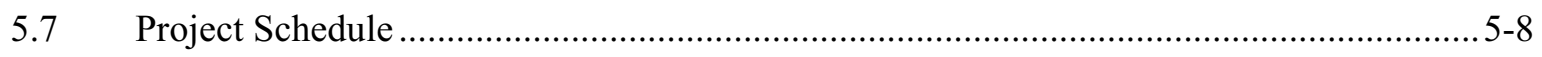

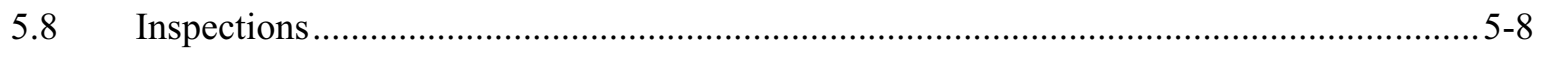

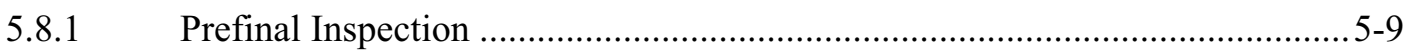

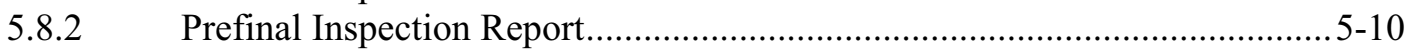

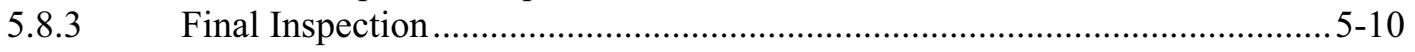

5.9 Remedial Action Sampling and Analysis Plan ...................................................... 5-10

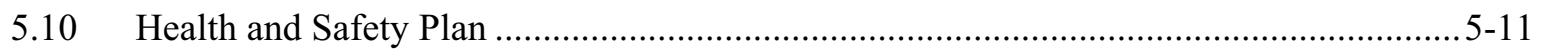

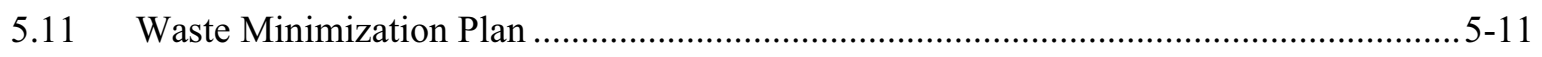

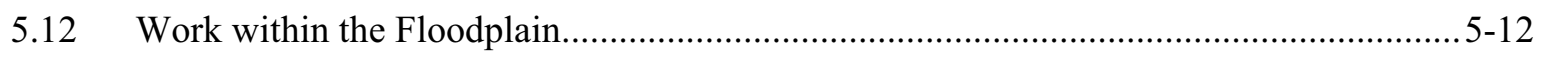

5.13 Decontamination Plan ......................................................................................... $5-12$

5.14 Spill Prevention/Response Program ..................................................................... 5-12

5.15 Operations and Maintenance Plan ........................................................................ 5-12

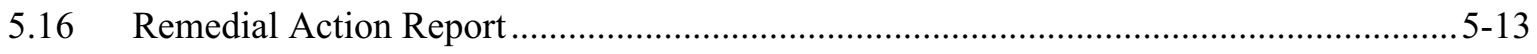

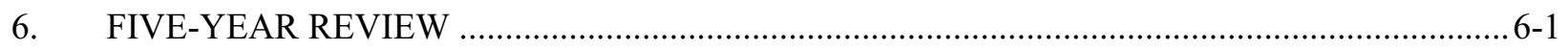

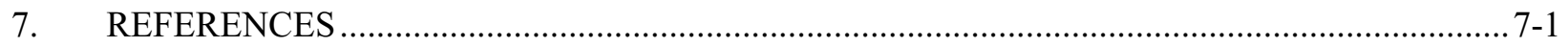


Appendix A-Air Emissions Analysis for Excavation of Lead-Contaminated Soils at the STF-02 Gun Range

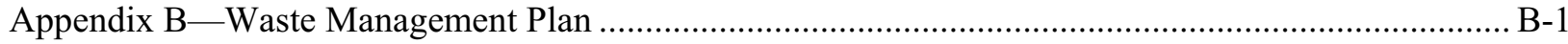

Appendix C-Operations and Maintenance Plan for Operable Units 6-05 and 10-04, Phase III............ C-1

Attachment 1 - Construction Specification

Att $1-1$

\section{FIGURES}

1-1. Map of the Idaho National Laboratory Site showing the locations of major facilities.................. 1-4

1-2. Location of Waste Area Group 10 Comprehensive Environmental Response, Compensation, and Liability Act sites at the Idaho National Laboratory ........................................................ 1-5

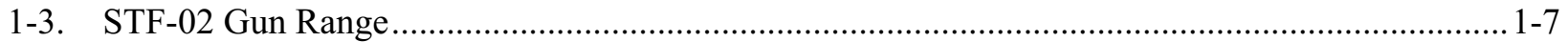

\section{TABLES}

4-1. Areas and volumes of contaminated media for the STF-02 Gun Range

4-2. Compliance with applicable or relevant and appropriate requirements and to-be-considered guidance for the STF-02 Gun Range

5-1. Phase III project cost estimate.

5-2. Remedial action schedule 


\section{ACRONYMS}

AAC acceptable ambient concentration

AACC acceptable ambient concentration for a carcinogen

ARAR applicable or relevant and appropriate requirement

CERCLA Comprehensive Environmental Response, Compensation, and Liability Act

CFA Central Facilities Area

CFR Code of Federal Regulations

CITRC Critical Infrastructure Test Range Complex

DEQ (Idaho) Department of Environmental Quality

DOE U.S. Department of Energy

DOE-ID U.S. Department of Energy Idaho Operations Office

EOCR Experimental Organic-Cooled Reactor

EPA U.S. Environmental Protection Agency

FR Federal Register

FY fiscal year

HAD hazard assessment document

HASP health and safety plan

ICDF Idaho CERCLA Disposal Facility

ICP Idaho Cleanup Project

IDAPA Idaho Administrative Procedures Act

INEEL Idaho National Engineering and Environmental Laboratory

INL Idaho National Laboratory

LDR land disposal restriction

MCP management control procedure

MFC Materials and Fuels Complex

NA not applicable 


$\begin{array}{ll}\text { NESHAP } & \text { National Emission Standards for Hazardous Air Pollutants } \\ \text { NPDES } & \text { National Pollutant Discharge Elimination System } \\ \text { NPR } & \text { New Production Reactor } \\ \text { NRF } & \text { Naval Reactors Facility } \\ \text { O\&M } & \text { operations and maintenance } \\ \text { OU } & \text { operable unit } \\ \text { PDD } & \text { program description document } \\ \text { PLN } & \text { plan } \\ \text { PPE } & \text { personal protective equipment } \\ \text { QA/QC } & \text { quality assurance/quality control } \\ \text { RAO } & \text { remedial action objective } \\ \text { RCRA } & \text { Resource Conservation and Recovery Act } \\ \text { RD/RA } & \text { remedial design/remedial action } \\ \text { ROD } & \text { Record of Decision } \\ \text { RTC } & \text { Reactor Technology Complex } \\ \text { RWMC } & \text { Radioactive Waste Management Complex } \\ \text { STF } & \text { Security Training Facility } \\ \text { TAN } & \text { Test Area North } \\ \text { TSDF } & \text { Treatment, Storage, and Disposal Facility } \\ \text { WAtes Code }\end{array}$




\section{Remedial Design/Remedial Action Work Plan for Operable Units 6-05 and 10-04, Phase III}

\section{INTRODUCTION}

In accordance with the Federal Facility Agreement and Consent Order for the Idaho National Engineering Laboratory (DOE-ID 1991) among the U.S. Department of Energy Idaho Operations Office (DOE-ID), the U.S. Environmental Protection Agency (EPA), and the Idaho Department of Environmental Quality (DEQ) - hereafter referred to as the Agencies - the DOE-ID submits this Remedial Design/Remedial Action (RD/RA) Work Plan for Operable Unit (OU) 10-04. Under the current remediation management strategy outlined in the Federal Facility Agreement and Consent Order for the Idaho National Engineering Laboratory (DOE-ID 1991), the location identified for the remedial action-hereafter referred to as OU 10-04-is designated as Waste Area Group (WAG) 6, OU 6-05, Experimental Breeder Reactor I/Boiling Water Reactor Experiment Area and WAG 10, OU 10-04 Miscellaneous Sites at the Idaho National Laboratory (INL) Site. In addition, WAG 10 includes OU 10-08, which was added to address INL-wide groundwater issues and new sites that are passed by other groups to WAG 10. Operable Unit 10-08 will prepare a separate OU 10-08 comprehensive remedial investigation/feasibility study and Record of Decision (ROD). Therefore, OU 10-04 will not address INL-wide groundwater issues or potential new sites.

As required by the Comprehensive Environmental Response, Compensation, and Liability Act (CERCLA) (42 USC § 9601 et seq.), the OU 10-04 remedial action will proceed in accordance with the Record of Decision Experimental Breeder Reactor-I/Boiling Water Reactor Experiment Area and Miscellaneous Sites, Operable Units 6-05 and 10-04 (DOE-ID 2002). The OU 10-04 ROD

(DOE-ID 2002) presents the selected remedies for 50 surface sites evaluated under the Comprehensive Remedial Investigation/Feasibility Study for Waste Area Groups 6 and 10 Operable Unit 10-04 (DOE-ID 2001).

The remedial action for OU 10-04 is divided into four phases. Phase I consists of developing and implementing institutional controls at OU 10-04 sites and developing and implementing INL-wide plans for both institutional controls and ecological monitoring. Phase II will remediate sites contaminated with trinitrotoluene and Royal Demolition Explosive. Phase III will remediate lead contamination at a gun range, and Phase IV will remediate hazards associated with unexploded ordnance. Separate RD/RA work plans will be submitted for each remediation phase. The scope and schedule for implementing these remediation phases are presented in Operable Units 6-05 and 10-04, Experimental Breeder Reactor-I/Boiling Water Reactor Experiment Area and Miscellaneous Sites, Remedial Design/Remedial Action Scope of Work (DOE-ID 2003).

Phase III activities will address the remediation of lead-contaminated soil found at the Security Training Facility (STF) -02 Gun Range located at the INL Site. The gun range berms, the surrounding soil, and the adjacent Experimental Organic-Cooled Reactor (EOCR) leach pond will be excavated to remove soil having lead contamination that exceeds the $400-\mathrm{mg} / \mathrm{kg}$ remediation goal. Physical separation of the lead and copper fragments (e.g., bullets and casings) from the soil will be performed, as feasible, to meet Resource Conservation and Recovery Act (RCRA) disposal criteria (42 USC § 6901 et seq.) with the lead and copper fragments being recycled. Soil that does not meet the RCRA disposal criteria will require stabilization prior to disposal. Soil that exceeds the remediation goal but meets the RCRA disposal criteria will be directly disposed of at the Idaho CERCLA Disposal Facility (ICDF). Soil that meets the remediation goal for lead will be returned to the site. 
In addition to the soil, creosote-contaminated railroad ties and power poles at the gun range will be removed and sent to an approved facility for disposal. A wooden building and asphalt pads will be removed and disposed of at the Central Facilities Area (CFA) landfill as nonhazardous construction debris. After the contaminated soil has been excavated, the area will be contoured to match the surrounding terrain and revegetated.

\subsection{Work Plan Organization}

The RD/RA for OUs 6-05 and 10-04 is divided into the following four phases:

- $\quad$ Phase I-institutional controls and ecological monitoring

- $\quad$ Phase II-remediation of trinitrotoluene- and Royal Demolition Explosive-contaminated sites

- $\quad$ Phase III-remediation of the STF-02 Gun Range

- $\quad$ Phase IV—remediation of ordnance-contaminated sites.

This RD/RA Work Plan outlines the major activities to be implemented in performing the Phase III activities for OU 10-04 in accordance with the OU 10-04 ROD (DOE-ID 2002). In addition, this RD/RA Work Plan describes the sites, contaminants, project management, tasks, schedules, and cost estimates. The following are brief descriptions of the RD/RA Work Plan's sections and appendixes:

- Section 1 describes the background and history of WAGs 6 and 10 and provides an overview of the selected remedy for the area of concern.

- $\quad$ Section 2 provides the design criteria, including the design codes and standards, assumptions, and quality assurance.

- Section 3 discusses the project's remedial design. A summary of the required activities is presented.

- $\quad$ Section 4 provides the initial evaluation of the lead-contaminated soil at the STF-02 Gun Range, including an evaluation of the potential risks to human health and the environment. A description of the existing site condition, potential migration and exposure pathways, and an assessment of exposure routes is provided. In addition, the remedial action objectives (RAOs) and applicable or relevant and appropriate requirements (ARARs) are identified.

- $\quad$ Section 5 outlines the OU 6-05 and 10-04 remedial action work plan. This section includes the necessary steps and documentation required to complete the remedial action for the STF-02 Gun Range, as described in Sections 1-4. The required work tasks, project cost estimates, inspections, environmental and safety plans, and sampling and analysis plans are discussed in this section.

- $\quad$ Section 6 describes the necessary actions involved for each 5-year review to occur after the remedial action has taken place. A 5-year review should not be necessary at the STF-02 Gun Range following the completion of the remedial action, as contamination exceeding the remedial action objectives will be removed. The site will be included in any Sitewide 5-year reviews performed prior to finalization of the Phase III remedial action report.

- $\quad$ Section 7 lists the reference material.

- $\quad$ Appendix A presents a summary of the air emissions modeling to satisfy project ARARs. 
- $\quad$ Appendix B describes the management and disposal of waste generated during Phase III activities.

- $\quad$ Appendix C provides the Operations and Maintenance (O\&M) Plan for OU 10-04 Phase III.

- Attachment 1 provides the project design drawings and contains the construction specifications that provide the general terms and conditions required to complete the remedial action.

- In addition, three separate documents are associated with this RD/RA Work Plan:

- $\quad$ The Field Sampling Plan for the Operable Units 6-05 and 10-04 Remedial Action, Phase III (DOE-ID 2006a) describes the sampling and analyses required during Phase III activities

- $\quad$ The Quality Assurance Project Plan for Waste Area Groups 1, 2, 3, 4, 5, 6, 7, 10, and Deactivation, Decontamination, and Decommissioning (DOE-ID 2006b) describes the necessary steps required to ensure project data quality

- $\quad$ The Miscellaneous Sites Cleanup Project Health and Safety Plan (PLN-2128) describes the possible hazards and the required steps to protect the health and safety of project workers.

\subsection{Background}

Located $51 \mathrm{~km}(32 \mathrm{mi})$ west of Idaho Falls, Idaho, the INL is a government-owned, contractor-operated facility managed by DOE-ID (Figure 1-1). Occupying 2,305 $\mathrm{km}^{2}\left(890 \mathrm{mi}^{2}\right)$ of the northeastern portion of the eastern Snake River Plain, the INL Site encompasses portions of five Idaho counties: (1) Butte, (2) Jefferson, (3) Bonneville, (4) Clark, and (5) Bingham.

As shown in Figure 1-2, WAG 10 is comprised of miscellaneous surface sites and liquid disposal areas throughout the INL that are not included within other WAGs (WAGs 1-9).

The STF area has been used since 1983 for security-force practice maneuvers, including small arms target practice in a berm approximately $76 \mathrm{~m}$ (250 ft) northeast of the former STF-601 (see Figure 1-3). The berm was used from 1983 to 1990. It is estimated that 5 million rounds were fired into the berm, including tracer rounds. None of the lead bullets that were fired into or that ricocheted away from the berm into the "kickout" areas have been picked up. Approximately 61 tons of lead and 3.4 tons of copper may be present at the site.

During sampling conducted in support of the remedial investigation conducted at the STF-02 Gun Range, two locations within the EOCR leach pond were visually identified as having lead bullets and fragments, presumably from activities conducted at the gun range located immediately adjacent to the pond. These locations were sampled and the resulting lead concentrations exceeded the $400-\mathrm{mg} / \mathrm{kg}$ remediation goal. As such, the EOCR leach pond is included with the STF-02 Gun Range for remediation of lead-contaminated soils. The pond was never actively used for its intended purpose; therefore, no other sources of contamination exist. 


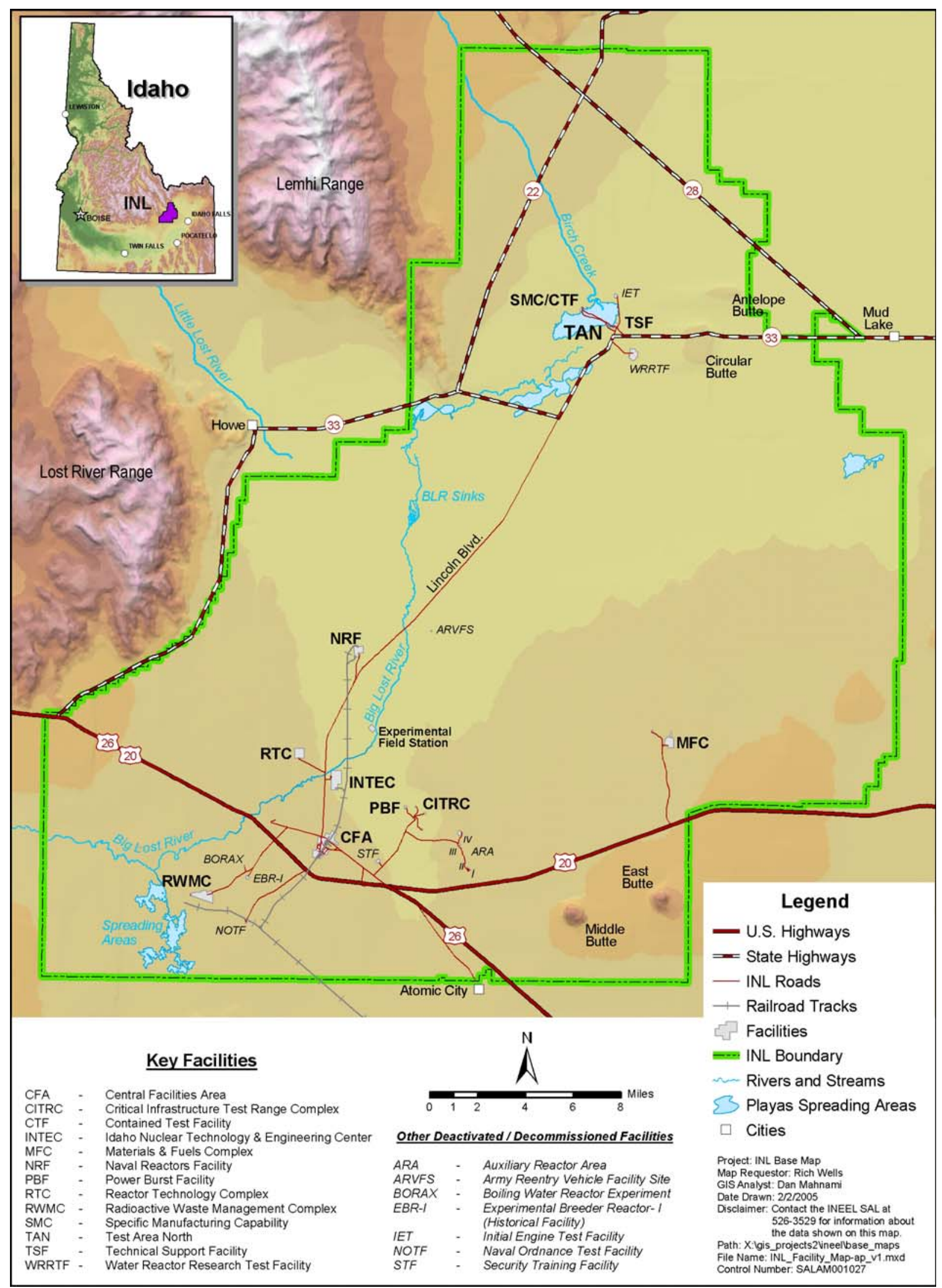

Figure 1-1. Map of the Idaho National Laboratory Site showing the locations of major facilities. 


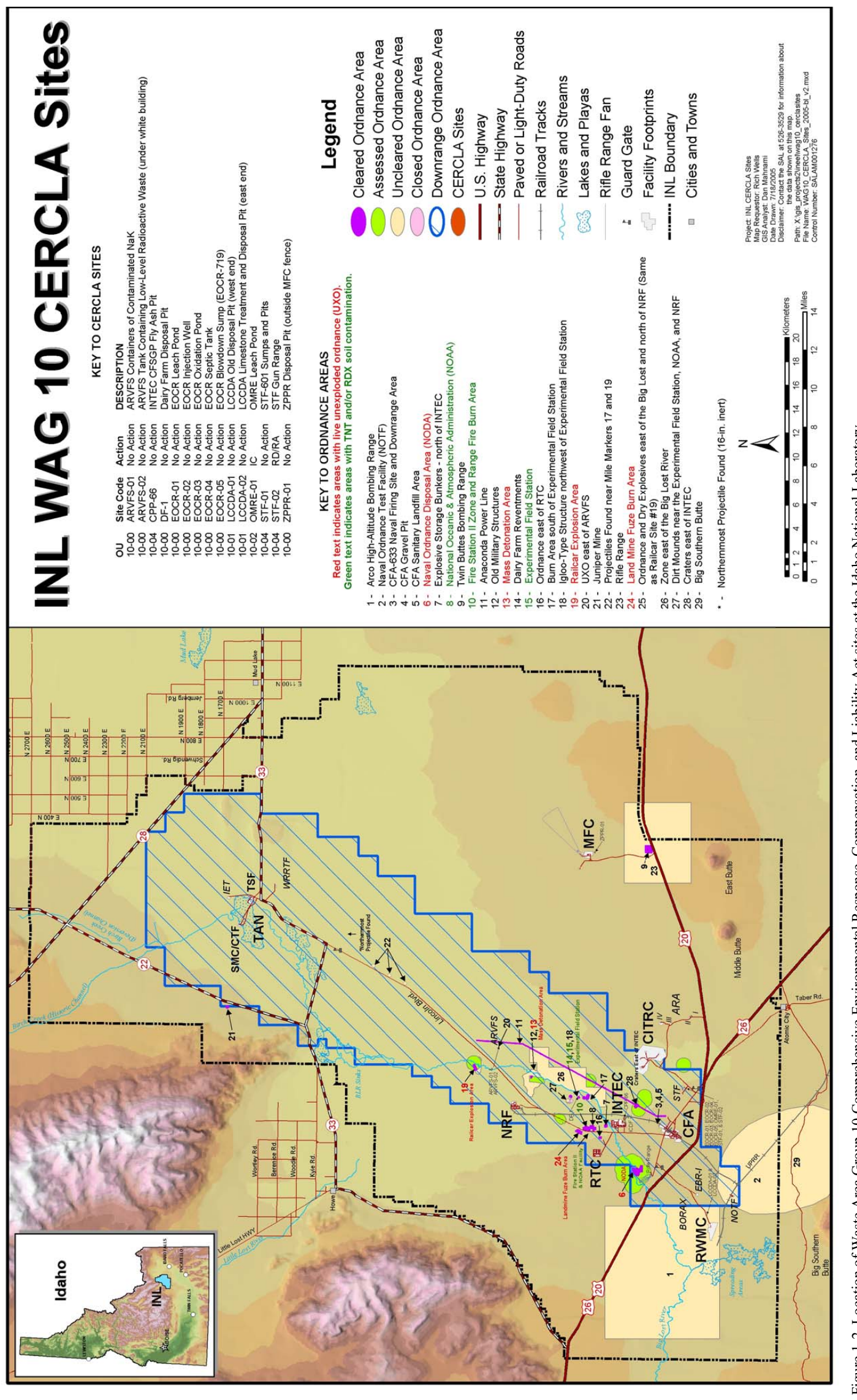




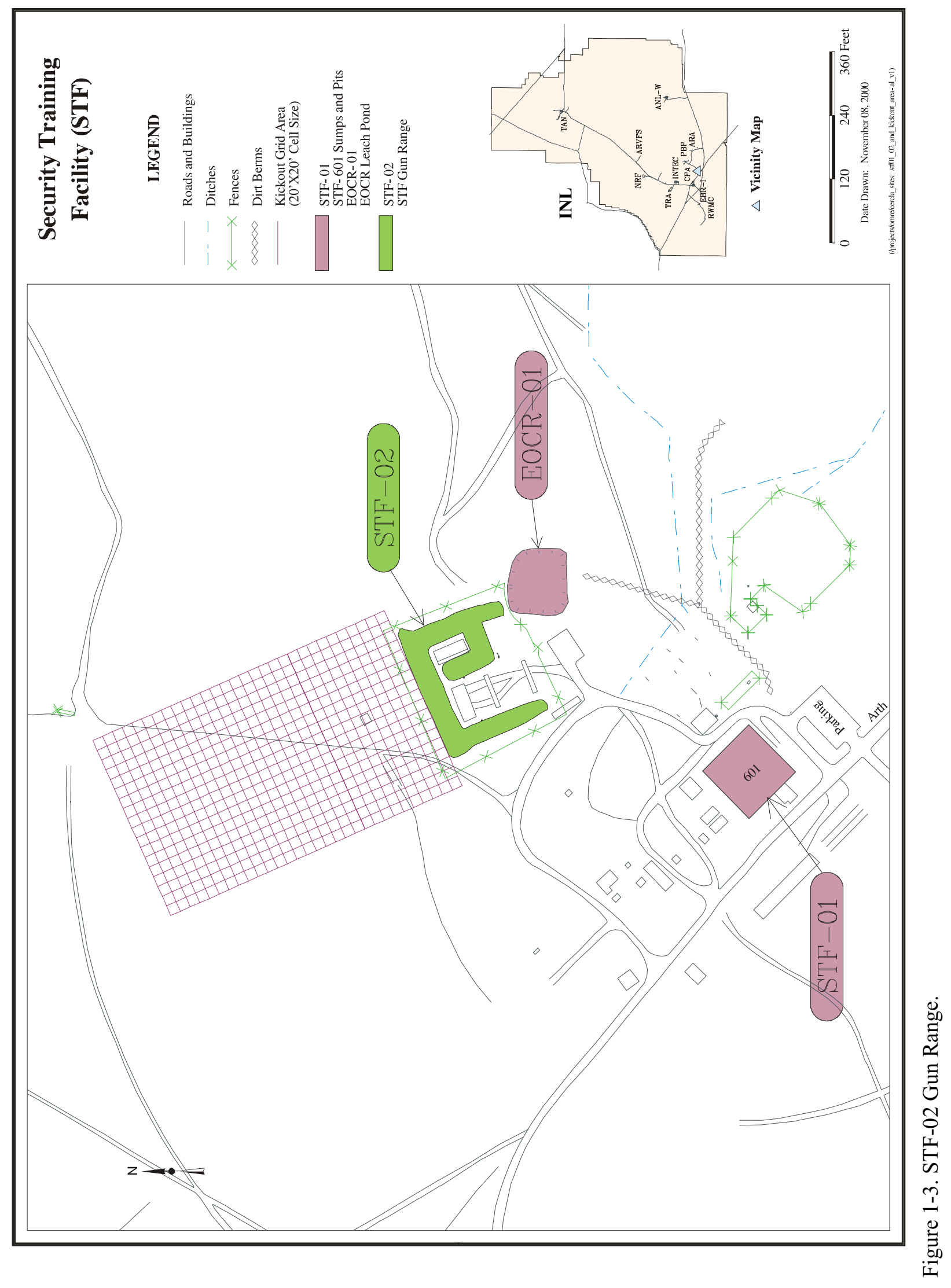




\subsection{Selected Remedy}

The remedial alternatives developed to address the STF-02 lead-contaminated soil site include the following:

- $\quad$ Alternative $1-$ no action

- $\quad$ Alternative 3-removal, ex situ treatment, and disposal or return to excavations

- $\quad$ Alternative 3a-removal (including physical separation to segregate the metal fragments and bullets), onsite stabilization, and disposal

- $\quad$ Alternative 3b-removal (including physical separation to segregate the metal fragments and bullets), onsite soil washing with acid to remove lead from soil determined to be RCRA characteristic for lead, and return of soil to the excavations.

Based upon consideration of the requirements of CERCLA (42 USC $\S 9601$ et seq.), the detailed analysis of alternatives, and public comments, the Agencies have selected Alternative 3a (removal, treatment, and disposal of soil on or off the INL) as the remedy for the STF-02 site. Removal of the contaminated soil will include the physical segregation of lead fragments and bullets from the soil. The segregated lead will be sent for recycling. As a secondary benefit of the physical segregation operation, copper fragments similarly will be removed from the soil and sent for recycling. Performance standards were implemented as design criteria to ensure that the selected remedy protects human health and the environment. 


\section{DESIGN BASIS}

\subsection{General Description of Project Components}

The project components (support facilities, electrical power, and project execution services) are described in the following subsections.

\subsubsection{Support Facilities}

The support facilities to be used during field operations include a field office trailer(s), parking area, and lay-down area. A supply trailer(s) will be required for field use. Parking for personnel vehicles will be established at the task site with approval of the project office. A lay-down area will be designated at the task site.

\subsubsection{Electrical Power}

Currently, electrical power is not available at the STF-02 site for field operations use. If power is required for field operations, either electrical generators must be provided or arrangements must be made with the Power Management organization to establish electrical power at the task site by using an available power line in the vicinity of the STF-02 site.

\subsubsection{Project Execution Services}

The O\&M contract will provide project execution services (e.g., ensuring that construction specifications are met and reviewing and improving construction interface documents) on an as-needed basis. In addition, engineering support will be provided during pre-field operation activities, field operation activities, and at-field operations closeout. During field operation activities, appropriate Contractor personnel will review and evaluate field changes.

\subsection{Design Criteria}

\subsubsection{Management Control Procedures}

The project definition, project planning, project execution, and project acceptance and closeout phases will be performed in accordance with the pertinent Contractor's internal company procedures. Pertinent internal company procedures for this project are those identifying requirements in the following areas:

- $\quad$ Engineering design

- $\quad$ Emergency preparedness and management

- $\quad$ Fire protection

- Management systems

- Occupational safety and health

- $\quad$ Security

- Environmental restoration

- Waste management 
- $\quad$ Conduct of operations and maintenance

- Quality

- Cultural resources.

The objectives of this remedial action are to prevent exposure to soils contaminated with lead at concentrations greater than $400 \mathrm{mg} / \mathrm{kg}$, prevent groundwater contamination, and inhibit ecological receptor exposures to soil contaminated with lead. The following subsection describes the activities at the STF-02 Gun Range covered under the Phase III activities.

\subsubsection{STF-02 Gun Range}

The remedial alternative developed to address lead-contaminated soil at the STF-02 Gun Range includes the following:

- $\quad$ Excavate the berms, surrounding soil, and the adjacent pond with mechanical equipment to remove soil above the remediation goal for lead. Field screening will be used to initially identify the extent of soil excavation required to meet the remediation goal.

- $\quad$ Perform physical separation to remove copper and lead fragments (e.g., bullets and casings), which will be recycled off the INL.

- $\quad$ After sorting, return soil containing lead in concentrations below the remediation goal to the site. Stabilize soil that is RCRA characteristic for lead and send it to an approved facility for permanent disposal. Dispose of soil that is above the remediation goal but is not RCRA characteristic for lead without further treatment at the ICDF.

- $\quad$ Encapsulate the railroad ties and power poles and send them to a RCRA-compliant landfill on or off the INL.

- Dispose of the wooden building and asphalt pads as nonhazardous construction debris on the INL in the CFA landfill or the ICDF.

- Sample and analyze soil to verify that the remediation goal is achieved. Because all contamination above the remediation goal will be removed, monitoring and sampling after remediation will not be required and the need for institutional control is not anticipated.

- $\quad$ Contour the excavated areas to match the surrounding terrain and vegetate.

\subsection{U.S. Department of Energy-Related Codes, Standards, and Documents}

The following U.S. Department of Energy (DOE) -related codes, standards, and documents will be used as the basis for remediation of the lead-contaminated soil site at the STF-02 Gun Range:

- $\quad$ Record of Decision Experimental Breeder Reactor-I/Boiling Water Reactor Experiment Area and Miscellaneous Sites, Operable Units 6-05 and 10-04 (DOE-ID 2002)

- DOE Order 414.1C, "Quality Assurance" 
- $\quad$ DOE Order 440.1A, "Worker Protection Management for DOE Federal and Contractor Employees"

- DOE Order 450.1, "Environmental Protection Program"

- DOE Order 460.1B, "Packaging and Transportation Safety"

- DOE Order 5480.4, "Environmental Protection, Safety, and Health Protection Standards"

- DOE Order 5480.19, "Conduct of Operations Requirements for DOE Facilities"

- DOE Manual 232.1-1A, "Environment, Safety, and Health Reporting Manual”

- DOE Manual 232.1-2, "Occurrence Reporting and Processing of Operations Information."

\subsection{Engineering Standards}

Attachment 1, "Construction Specification-Remediation of the STF-02 Gun Range," contains references to the latest engineering standards and the specifications to which they apply.

\subsection{Environmental and Safety}

The following is a list of potential chemical-specific and action-specific ARARs identified in the OU 10-04 ROD (DOE-ID 2002). A detailed discussion of the ARARs is presented in Section 4.2, "Applicable or Relevant and Appropriate Requirements."

\section{Chemical-specific ARAR:}

- Idaho Administrative Procedures Act (IDAPA) 58.01.11.200, "Ground Water Quality Standards."

\section{Action-specific ARARs:}

- IDAPA 58.01.01.11, "Definitions for the Purposes of Sections 790 through 799”

- IDAPA 58.01.01.161, “Toxic Substances”

- IDAPA 58.01.01.500.02, "Compliance with Rules and Regulations"

- IDAPA 58.01.01.585, "Toxic Air Pollutants Non-Carcinogenic Increments"

- IDAPA 58.01.01.586, "Toxic Air Pollutants Carcinogenic Increments"

- IDAPA 58.01.01.650, "Rules for Control of Fugitive Dust"

- IDAPA 58.01.01.651, "General Rules”

- IDAPA 58.01.05.005, "Identification and Listing of Hazardous Waste"

- IDAPA 58.01.05.006, "Standards Applicable to Generators of Hazardous Waste"

- IDAPA 58.01.05.008, "Standards for Owners and Operators of Hazardous Waste Treatment, Storage, and Disposal Facilities"

- IDAPA 58.01.05.011, "Land Disposal Restrictions" 
- $\quad 40$ Code of Federal Regulations (CFR) 63.543(a), "Standards for Process Sources"

- $\quad 40$ CFR 122.26, "Storm Water Discharges (Applicable to State NPDES Programs, see $\S 123.25$ )"

- $\quad 40$ CFR 261.6(a)(b), "Requirements for Recyclable Materials"

- $\quad 40$ CFR 262.11, "Hazardous Waste Determination"

- $\quad 40$ CFR 264.1(j)(1-13), "Purpose, Scope, and Applicability"

- $\quad 40$ CFR 264.114, "Disposal or Decontamination of Equipment, Structures, and Soils”

- $\quad 40$ CFR 264.171, "Condition of Containers"

- $\quad 40$ CFR 264.172, "Compatibility of Waste with Containers"

- $\quad 40$ CFR 264.173, "Management of Containers"

- $\quad 40$ CFR 264.174, "Inspections"

- $\quad 40$ CFR 264.175, "Containment"

- $\quad 40$ CFR 264.176, "Special Requirements for Ignitable or Reactive Waste"

- $\quad 40$ CFR 264.177, "Special Requirements for Incompatible Wastes”

- $\quad 40$ CFR 264.554, "Staging Piles"

- $\quad 40$ CFR 268.40(a)(b)(e), “Applicability of Treatment Standards"

- $\quad 40$ CFR 268.45(a-d), "Treatment Standards for Hazardous Debris"

- $\quad 40$ CFR 268.48(a), "Universal Treatment Standards”

- $\quad 40$ CFR 268.49, “Alternative LDR Treatment Standards for Contaminated Soil.”

\section{Location-specific ARARs:}

- $\quad 17$ USC $\S 470$ h-2, "Historic Properties Owned or Controlled by Federal Agencies"

- $\quad 25$ USC $\S 3002$ et seq., "Ownership"

- 25 USC 3005 et seq., "Repatriation"

- 36 CFR 800.4, "Identification of Historic Properties"

- $\quad 36$ CFR 800.5, “Assessment of Adverse Effects”

- $\quad 43$ CFR 10.6, "Custody"

- $\quad 43$ CFR 10.10, "Repatriation."

\subsection{Quality Assurance}

The "Hazard Assessment Document for the STF-02 Security Training Facility Gun Range Remediation" (HAD-329) addresses this project's activities. Based upon the comparison of the project's activities to the "routinely accepted hazard thresholds," none of the thresholds have been exceeded. Therefore, in accordance with guidance given in "Interim Guidance for Less Than Hazard Category 3 (LTHC3) Safety Basis Documentation" (Hobbes 2004), the STF-02 Gun Range remediation project is designated as a routinely accepted hazard. There are no unique or significant hazards associated with the project; therefore, only Contractor-level approval of this designation is required, and no further safety 
documentation is necessary. Because no safety structures, systems, and components have been identified that must function to prevent or mitigate the project's hazards, a safety category designation of "consumer grade" is appropriate for the remedial activities as defined in Management Control Procedure (MCP) -540, "Assigning Quality Levels."

The "Project Execution Plan for the Miscellaneous Sites Cleanup" (PLN-2087) has been adopted for this project and is incorporated by reference. The guidance governs the functional activities, organization, and quality assurance/quality control (QA/QC) protocols that will be used for this project. The Quality Assurance Project Plan for Waste Area Groups 1, 2, 3, 4, 5, 6, 7, 10, and Deactivation, Decontamination, and Decommissioning (DOE-ID 2006b) also has been adopted for this project. This plan governs the QA/QC requirements for data. The "Field Sampling Plan for the Operable Units 6-05 and 10-04 Remedial Action, Phase III" (DOE-ID 2006a) describes the QA/QC requirements for field sampling and analysis of field survey samples for lead using both field and laboratory-based x-ray fluorescence instrumentation. Where applicable, the construction specifications (provided in Attachment 1) will specify the QA/QC procedures for the given task, consistent with guidance provided by PLN-2087, "Project Execution Plan for the Miscellaneous Sites Cleanup." 


\section{REMEDIAL DESIGN}

\subsection{Project Site}

This section describes the remedial design for the STF-02 Gun Range. The remedial design was developed in accordance with the engineering design criteria presented in Section 2, "Design Basis." The construction specifications for the action are included in Attachment 1. The following subsections summarize the major aspects critical to the remedial design.

\subsection{Site Contaminant Summary}

Sampling of the STF-02 Gun Range was conducted in 2000 in accordance with the Field Sampling Plan for Operable Unit 10-04 Security Training Facility Gun Range (Final) (INEEL 2000). Two larger areas of concern were identified following the field sampling, including: (1) two kickout areas and (2) the remainder area consisting of the berms, the area between the berms, the sand area, the shooting house, and the area around the EOCR leach pond. The analytical results for these two areas were grouped for risk assessment purposes.

For the kickout areas, soil samples were collected from the 0 - to $0.15-\mathrm{m}(0-$ to $0.5-\mathrm{ft})$ and the 0.15 - to $0.45-\mathrm{m}(0.5-$ to $1.5-\mathrm{ft})$ intervals and submitted for metals analyses. The maximum detected concentrations were associated with the 0 - to $0.15-\mathrm{m}(0-$ to $0.5-\mathrm{ft})$ interval. The contaminants of potential concern with the maximum concentration provided in parentheses included arsenic $(6.3 \mathrm{mg} / \mathrm{kg})$, copper $(23.2 \mathrm{mg} / \mathrm{kg})$, lead $(70.2 \mathrm{mg} / \mathrm{kg})$, manganese $(530 \mathrm{mg} / \mathrm{kg})$, and selenium $(0.48 \mathrm{mg} / \mathrm{kg})$. None of these contaminants posed a concern from an ecological risk perspective. Lead was the only metal retained as a contaminant of potential concern from a human health risk assessment perspective.

For the remainder area, soil samples were again collected from the 0 - to $0.15-\mathrm{m}(0-$ to $0.5-\mathrm{ft})$ and the 0.15 - to $0.45-\mathrm{m}(0.5-$ to $1.5-\mathrm{ft})$ intervals and submitted for metals analyses. For the maximum detected concentrations, only selenium and sodium were associated with the 0 - to $0.15-\mathrm{m}(0-$ to $0.5-\mathrm{ft})$ depth interval, with the remaining maxima occurring in the 0.15 - to $0.45-\mathrm{m}(0.5-$ to $1.5-\mathrm{ft})$ depth range. The contaminants of potential concern with the maximum concentration provided in parentheses included antimony $(14.9 \mathrm{mg} / \mathrm{kg})$, arsenic $(8.7 \mathrm{mg} / \mathrm{kg})$, cadmium $(19.8 \mathrm{mg} / \mathrm{kg})$, lead $(24,400 \mathrm{mg} / \mathrm{kg})$, selenium $(0.66 \mathrm{mg} / \mathrm{kg})$, thallium $(0.9 \mathrm{mg} / \mathrm{kg})$, and zinc $(422 \mathrm{mg} / \mathrm{kg})$.

From a human health risk assessment perspective, lead was the only metal retained as a contaminant of potential concern, because the maximum concentration exceeded the risk-based concentration. A human health risk assessment could not be performed for the STF-02 Gun Range, because cancer slope factors were not available for lead. The maximum lead concentration was more than six times greater than the 400-mg/kg screening level provided in EPA guidance (EPA 1994); therefore, lead was retained as a contaminant of concern, thereby requiring remediation of the site. The ecological risk assessment reviewed the potential impact of copper, lead, manganese, and selenium on ecological receptors for the kickout area. It was determined that the kickout area did not pose an unacceptable risk to ecological receptors from exposure to soil at the site; therefore, none of the contaminants of potential concern were retained for further evaluation in the ecological risk assessment. For the remainder area, the ecological risk assessment reviewed the potential impact of antimony, copper, lead, selenium, and zinc on ecological receptors. The ecological risk evaluation for the remainder area determined that lead posed an unacceptable risk to ecological receptors. Based upon these evaluations, it was determined that the STF-02 Gun Range, particularly the remainder area, posed an unacceptable risk to human health and the environment from exposure to lead in the soil. 


\subsection{Site Preparation}

Plot plans delineating the lay-down areas will be prepared before field activities commence. The following general site-preparation activities apply to the STF-02 Gun Range addressed in this RD/RA Work Plan. Any special requirements are provided in the construction specifications included in Attachment 1, "Construction Specification." A summary of planned activities for the site include the following:

- $\quad$ The method for hauling contaminated soil will be approved by the Contractor

- $\quad$ Excavation boundaries will be established in accordance with the construction specifications

- Decontamination and lay-down areas will be established as directed by the Contractor.

\subsection{Earthwork}

All earthwork involving excavation and backfill will be graded following backfill (not all areas will require backfill) to encourage drainage away from the excavation. Those areas that are disturbed by earthwork activities will be revegetated. Standard dust-control measures (e.g., water spray, stop work during high winds, and soil fixatives) will be employed during all earthworks.

\subsection{Surface Water}

Contouring and grading backfilled areas will be performed to maintain existing surface water flow patterns at the task site. To note, not all excavations will require backfilling, but areas will be contoured for drainage and revegetated or otherwise stabilized. Revegetation of the backfilled excavations will be performed to control the growth of noxious weeds.

\subsection{Task-Site Staging}

A lay-down area will be necessary at the task site to stage equipment and materials close to the work. The staging area will be located so that noncontaminated materials and equipment operate in work areas isolated from contaminated materials and equipment. A temporary decontamination area for personnel and equipment will be established at the control point for the area in accordance with the decontamination requirements of the Miscellaneous Sites Cleanup Project Health and Safety Plan (PLN2128). Spill prevention and control will be maintained for the lay-down area. The lay-down area will be selected based upon several factors. Meteorological data will be considered to ensure that the lay-down area is not located in an area downwind from the prevalent wind direction at the task site. Included among the other considerations for selecting the lay-down area at the task site will be (a) the proximity to the area believed to require the greatest amount of excavation work, (b) selection of a clean area based upon health and safety considerations, (c) available infrastructure (i.e., power), and (d) the topography of the site (e.g., undulating vs. flat). The combination of criteria will form the basis for selecting the staging area. Following the completion of all field activities, the task-site staging area will be reclaimed in accordance with the construction specifications for earthwork and revegetation. 


\section{HUMAN HEALTH AND ENVIRONMENTAL COMPLIANCE}

\subsection{Remedial Action Objectives}

The remedial action objectives for the STF-02 Gun Range were developed in accordance with 40 CFR 300, "National Oil and Hazardous Substances Pollution Contingency Plan," and Guidance for Conducting Remedial Investigations and Feasibility Studies Under CERCLA (EPA 1988) and through the consensus of DOE-ID, EPA, and DEQ participants. The RAOs are based on the results of both human health requirements and the ecological risk assessments and are specific to lead as the only contaminant of concern.

The RAOs specified for protecting human health are expressed both in terms of risk and exposure pathways, because protection can be achieved by reducing contaminant levels and restricting or eliminating exposure pathways. The RAOs specified for protecting ecological receptors inhibit adverse effects from contaminated soil on resident populations of flora and fauna. The RAOs developed to protect human health and ecological receptors are as follows:

- $\quad$ Prevent exposure to soils contaminated with lead at concentrations greater than $400 \mathrm{mg} / \mathrm{kg}$

- Prevent groundwater contamination

- Inhibit ecological receptor exposures to soil contaminated with contaminants of concern, primarily concentrations in soils that result in a hazard quotient greater than or equal to 10.0.

The RAO excludes naturally occurring elements and compounds that are not attributable to historic releases. Remediation goals were established to meet these objectives. The remediation goal for lead to be protective of both human health and ecological receptors is $400 \mathrm{mg} / \mathrm{kg}$. A discussion pertaining to the applicability of the $400-\mathrm{mg} / \mathrm{kg}$ remediation goal based upon the human health screening level being protective of ecological receptors is provided in Appendix K of the Comprehensive Remedial Investigation/Feasibility Study for Waste Area Groups 6 and 10 Operable Unit 10-04 (DOE-ID 2001). The remediation goal can be satisfied by cleaning up to the identified contaminant concentration in the soil to below $400 \mathrm{mg} / \mathrm{kg}$. Removal of the contaminated media and metal debris from the STF-02 Gun Range will further reduce any potential groundwater risk. The areas and volumes of contaminated media and debris at the STF-02 Gun Range are presented in Table 4-1.

Table 4-1. Areas and volumes of contaminated media for the STF-02 Gun Range.

\begin{tabular}{|c|c|c|c|}
\hline $\begin{array}{c}\text { Contaminated } \\
\text { Media and Debris }\end{array}$ & $\begin{array}{c}\text { Area } \\
\left(\mathrm{m}^{2}\left[\mathrm{yd}^{2}\right]\right)\end{array}$ & $\begin{array}{c}\text { Contaminated Soil Volume } \\
\left(\mathrm{m}^{3}\left[\mathrm{yd}^{3}\right]\right)\end{array}$ & $\begin{array}{l}\text { Waste and Debris Volume } \\
\left(\mathrm{m}^{3}\left[\mathrm{yd}^{3}\right]\right)\end{array}$ \\
\hline Gun range soil & $9,570(11,450)$ & $14,900(19,450)$ & NA \\
\hline Leach pond soil & $1,300(1,600)$ & $405(530)$ & NA \\
\hline $\begin{array}{l}96 \text { Creosote-treated railroad ties } \\
(6 \text { in. } \times 8 \text { in. } \times 10 \mathrm{ft})\end{array}$ & NA & NA & $9.1(11.9)$ \\
\hline Power poles & NA & NA & $0.9(1.2)$ \\
\hline Asphalt/concrete pads & $269(322)$ & NA & $41.1(53.7)^{\mathrm{a}}$ \\
\hline Wooden building & NA & NA & $3.8(5)$ \\
\hline $\begin{array}{l}\text { Lead debris (fragments and } \\
\text { unfired rounds) }\end{array}$ & NA & NA & $4.8(6.3)$ \\
\hline $\begin{array}{l}\text { Copper debris (fragments and } \\
\text { unfired rounds) }\end{array}$ & NA & NA & $0.2(0.3)$ \\
\hline $\begin{array}{l}\text { a. Assuming a combined thickness of } 0.1 \\
\mathrm{NA}=\text { not applicable }\end{array}$ & (6 in.) of concrete an & asphalt & \\
\hline
\end{tabular}




\subsection{Applicable or Relevant and Appropriate Requirements}

Table 4-2 summarizes how the substantive requirements of the ARARs and the to-be-considered requirements for the OU 10-04 Phase III contaminated soil site have been addressed by the remedial design or will be addressed during the remedial action. The substantive requirements of the RCRA and IDAPA ARARs specific to hazardous waste will be met for those media where RCRA hazardous constituents might be present. These requirements are not applicable to those media that are not RCRA hazardous. Use of air monitoring and dust-suppression techniques during excavation will ensure compliance with emission ARARs. The site has been surveyed for cultural and archaeological resources (see Appendix C), and appropriate actions will be taken to satisfy ARARs for protection of sensitive resources. If cultural resources are encountered, the requirements delineated in the Idaho National Laboratory Cultural Resources Management Plan (DOE-ID 2005) will be invoked. 


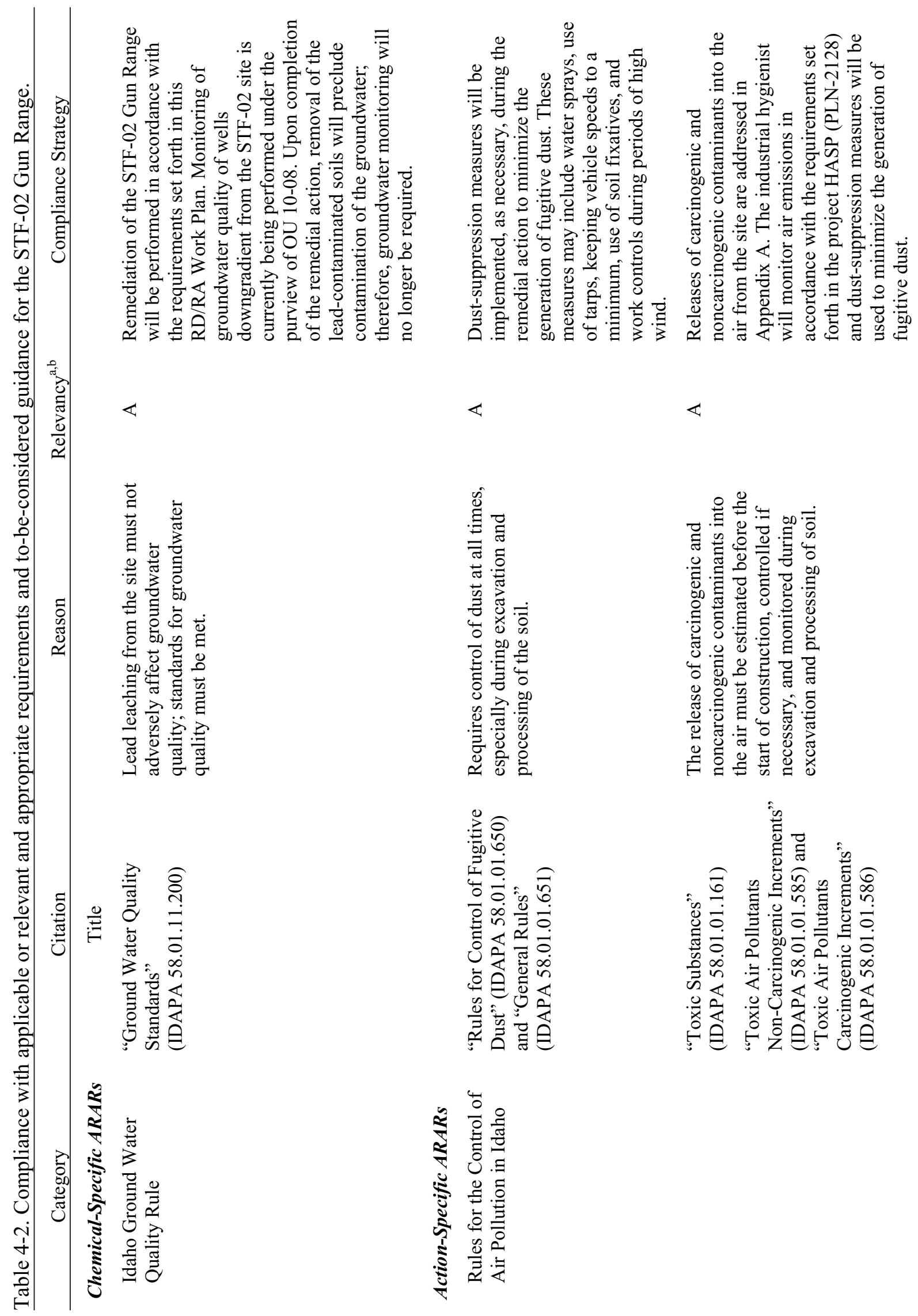




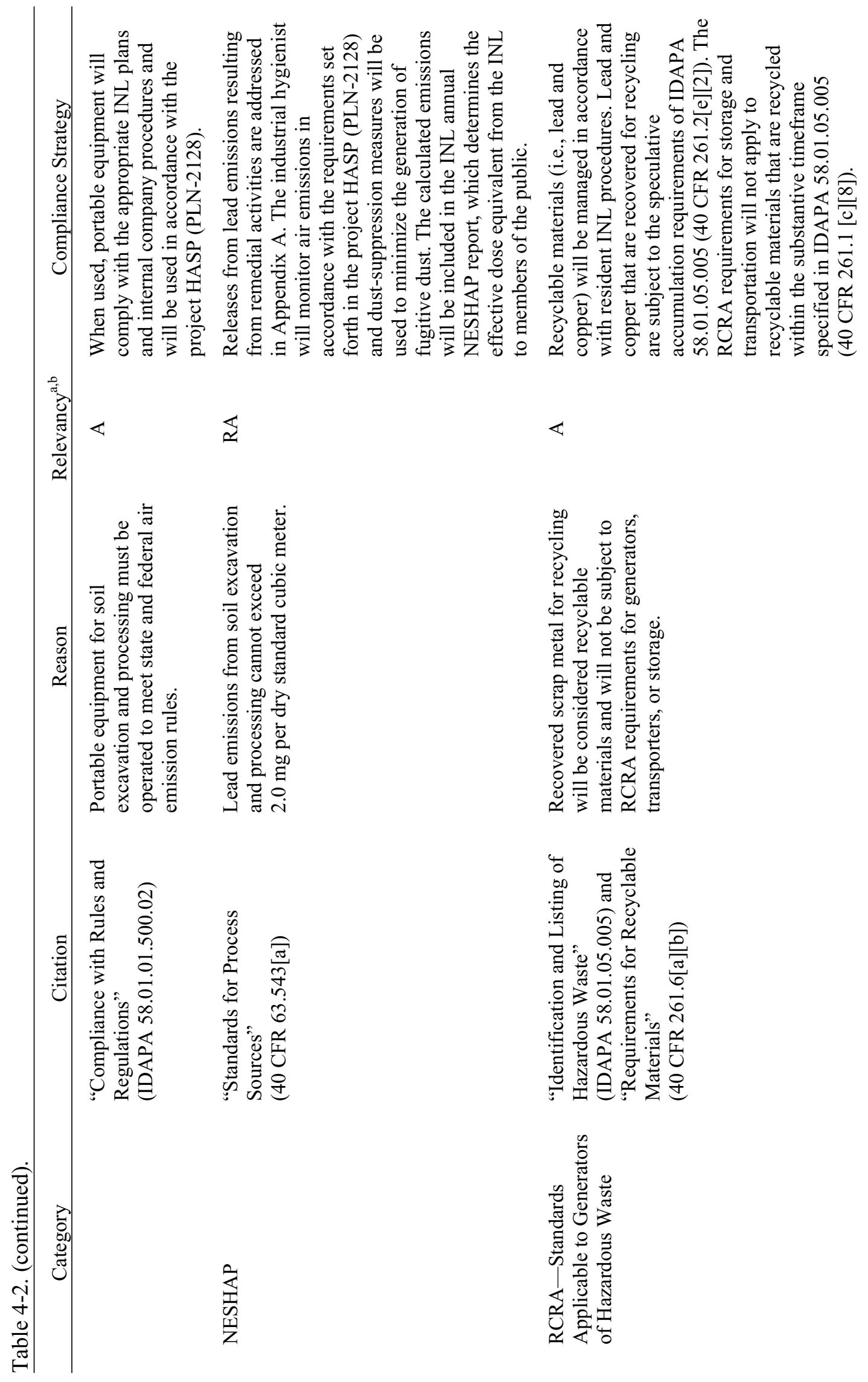




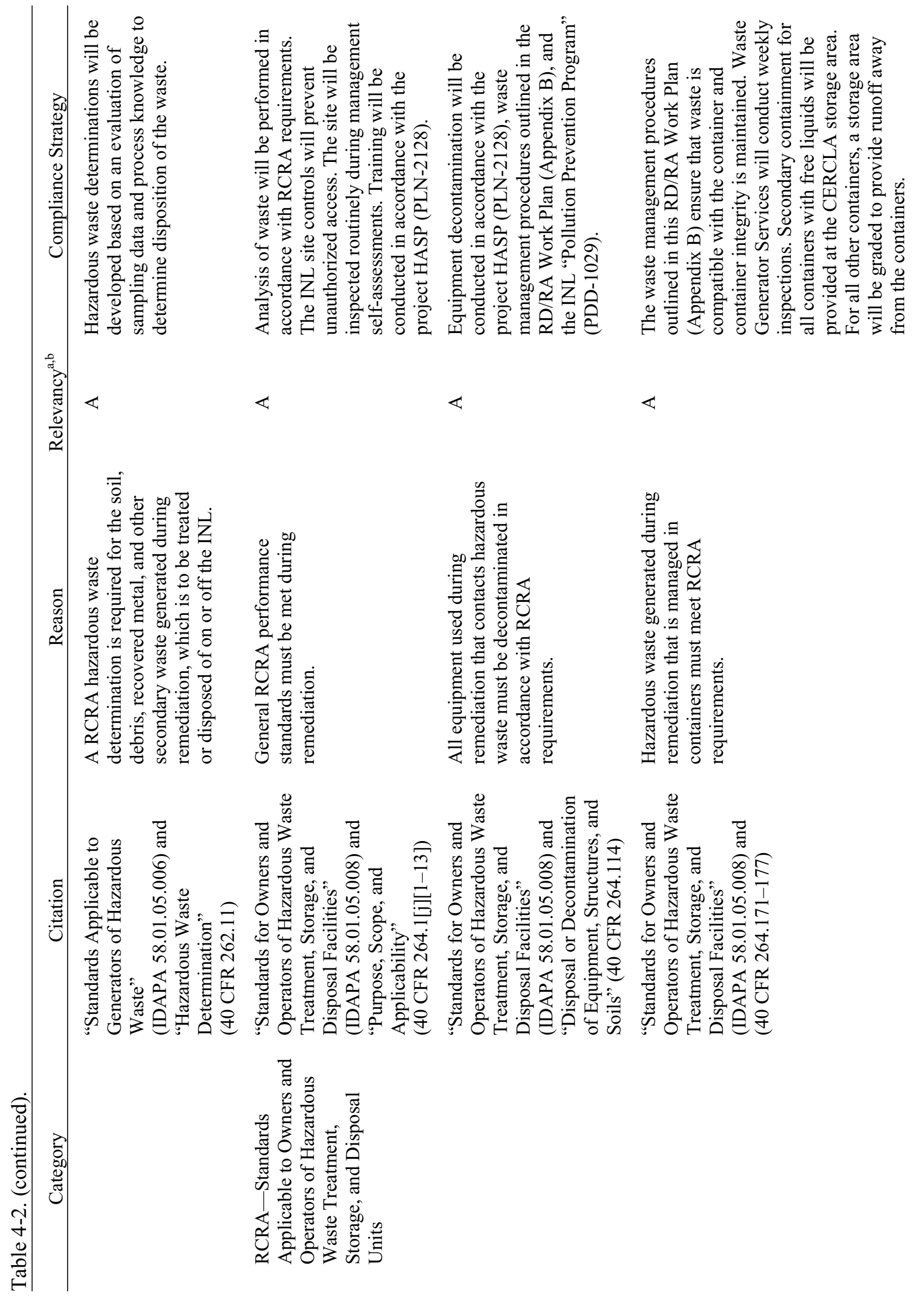




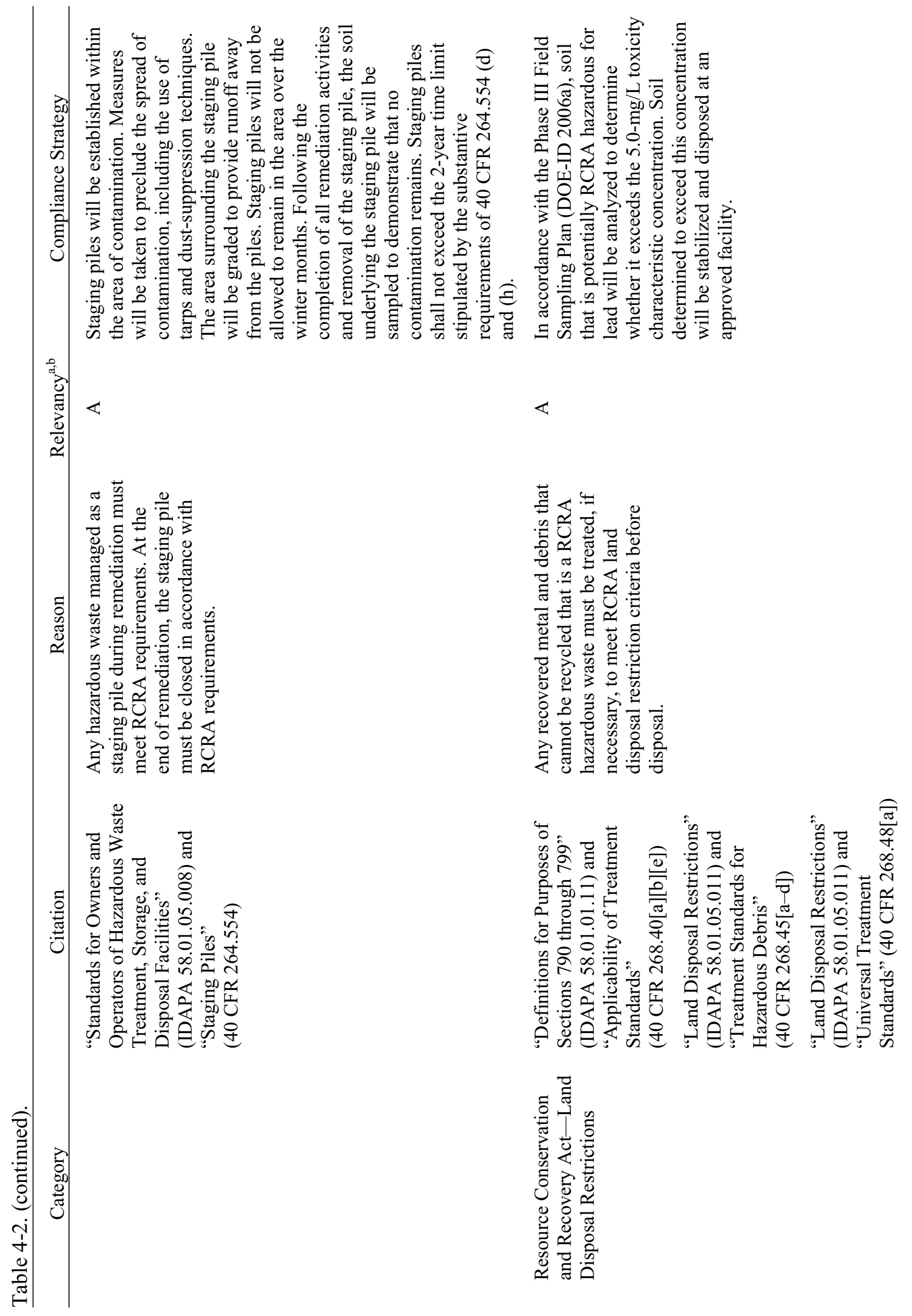




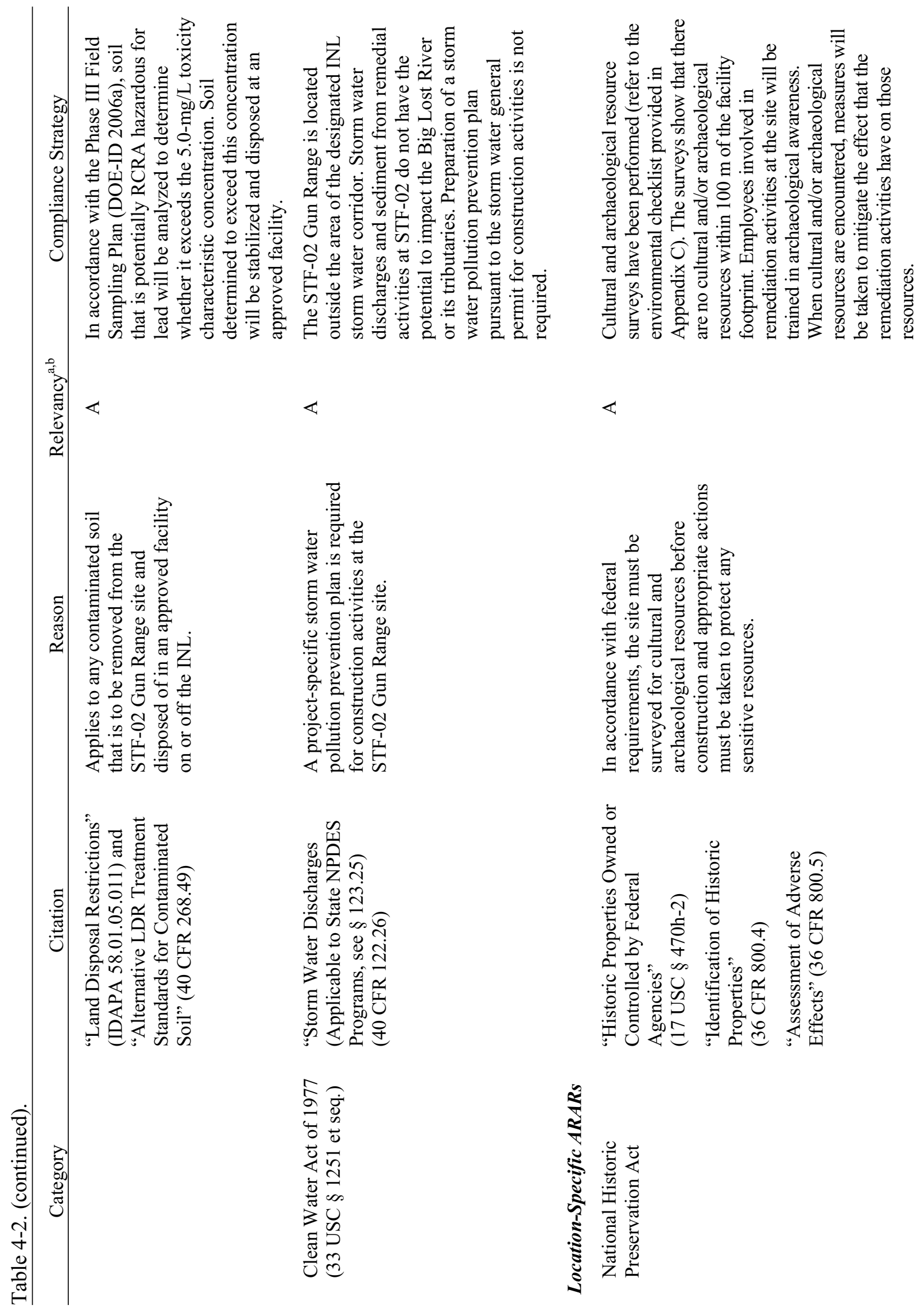




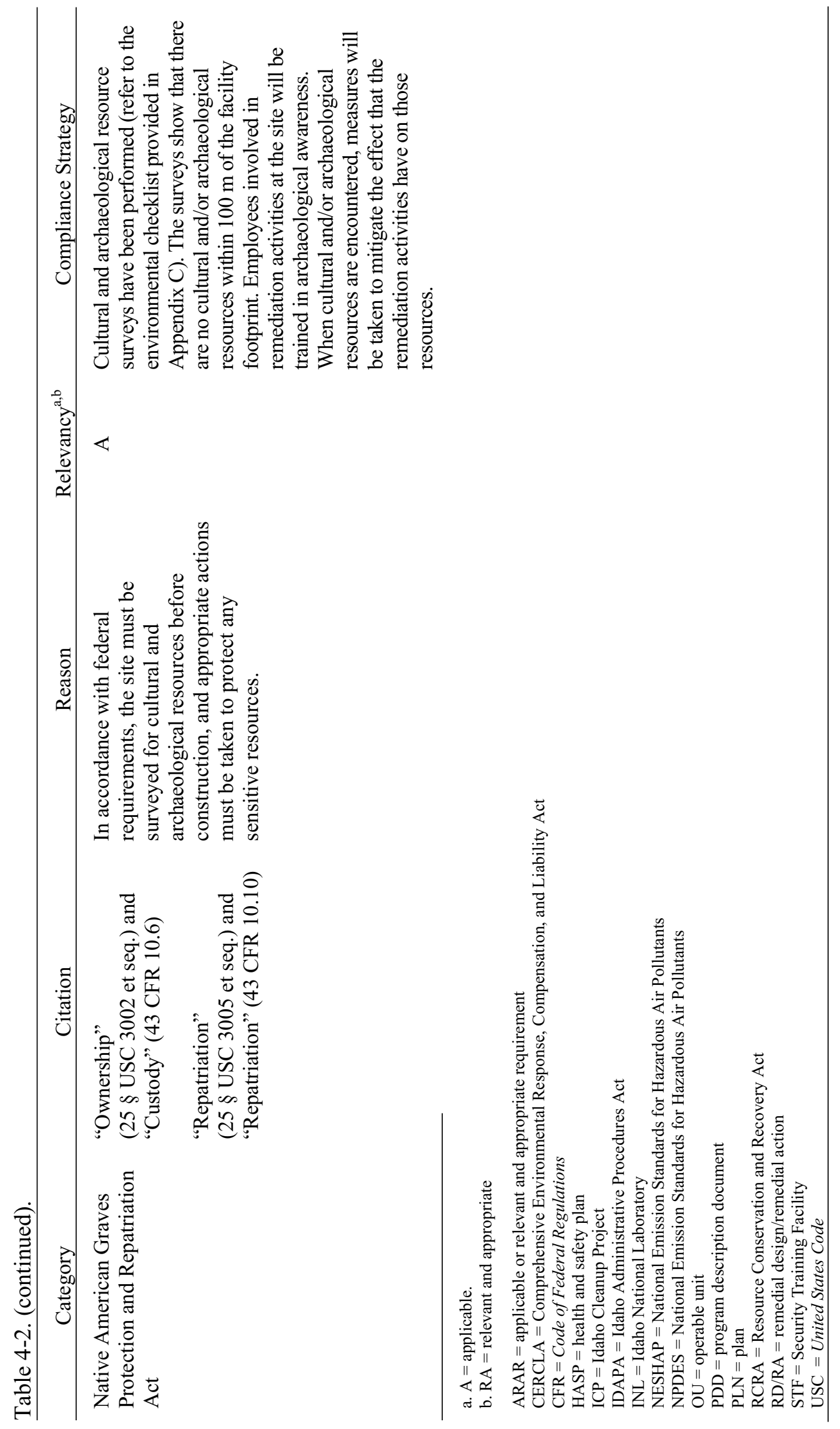




\section{REMEDIAL ACTION WORK PLAN}

This section details the management approach to the remedial action, including schedule and the necessary steps and documentation to perform the remedial action and document its completion. This section describes the elements necessary to implement the remedial design outlined in Sections 1-4. Because the remedial design and the remedial action work plan are combined into one document (i.e., this report), some details of implementation have been described in the design portion of this document for clarity.

\subsection{Relevant Changes to the Scope of Work}

The OU 10-04 ROD (DOE-ID 2002) and the Operable Units 6-05 and 10-04, Experimental Breeder Reactor-I/Boiling Water Reactor Experiment Area and Miscellaneous Sites, Remedial Design/Remedial Action Scope of Work (DOE-ID 2003) provide that the STF-02 Gun Range soils will undergo physical separation treatment to partition the heavy metal particles from the soil, based on the differences in physical properties (e.g., density, size, and shape).

\subsection{Design Assumptions}

The assumptions under which the STF-02 Gun Range remedial activities will be performed for the remediation of the site are as follows:

- Archaeological concerns will be identified before implementing the remedial action and will not delay planned activities

- $\quad$ Non-RCRA-characteristic contaminated soil that is contaminated above the remediation goals will be directly disposed of at the ICDF

- $\quad$ The RCRA-characteristic contaminated soil will be stabilized and disposed of at an off-Site, approved facility

- $\quad$ Ecological risks will be reduced by the remedial action that is implemented to reduce the human health risk for the STF-02 Gun Range

- The remediation goal that is based on a hazard quotient of 10 is protective of ecological receptors

- $\quad$ The soil, and creosote-treated railroad ties and power poles at the STF-02 Gun Range are only RCRA-regulated for lead, and no other contaminants exist that would be RCRA-regulated (42 USC $\S 6901$ et seq.).

\subsection{Work Tasks}

For the purposes of this RD/RA Work Plan, "Contractor" refers to the current O\&M Contractor. "Subcontractor" means the business entity contracted to provide the materials, supplies, and/or services discussed herein. The following subsections summarize the primary work tasks critical to completing the activities specified in this RD/RA Work Plan. 


\subsubsection{Premobilization}

The O\&M Construction Management personnel assigned to this project will provide all required work orders. All Contractor and Subcontractor required training and current medical examinations and information required by the Miscellaneous Sites Cleanup Project Health and Safety Plan (PLN-2128) will be provided prior to mobilizing to the task site.

\subsubsection{Mobilization}

Mobilization describes the tasks that must be performed to prepare for field operations. These tasks are generally the required administrative, engineering, and health and safety controls that must be implemented prior to the commencement of field activities and include, but are not limited to, the following:

- $\quad$ Emplacing required fences, signs, and postings

- $\quad$ Identifying and demarking task sites

- Delivering and storing required material and equipment

- $\quad$ Setting up the site offices for field operations (as required)

- $\quad$ Establishing the required lay-down areas

- $\quad$ Establishing the required decontamination areas.

\subsubsection{Clearing the Site}

The task site will be cleared of shrubs, vegetation, fences, and other debris in accordance with "Specification 02200-Earthwork," which is provided in Attachment 1 of this document. Because of the potential uptake of contamination attributed to lead and lead-contaminated soil, the vegetation will be collected along with the excavated soil for disposal.

Clearing operations will be confined to the soil site to be remediated and will be limited to only those areas requiring excavation, those areas required for establishing barriers (required as needed to designate the task-site work zones in accordance with the project health and safety plan [HASP]), or as directed by INL project personnel. The Subcontractor will repair and reseed any areas outside the designated areas that are damaged or disturbed by field operations in accordance with "Section 02486-Revegetation," which is provided in Attachment 1 of this document.

\subsubsection{Soil Excavation and Consolidation}

Soil excavation will be limited to only that soil necessary to remediate the task site. Excavated soil will be consolidated, as necessary, in a designated area immediately adjacent to the task site. All excavation and consolidation activities will be performed in accordance with "Specification 02200-Earthwork," which is provided in Attachment 1 of this document. To minimize the spread of contamination, equipment necessary for soil excavation will remain within the contamination control zones until completion of excavation activities. The remaining soil berms shall be graded to approximate the surrounding terrain.

Precautions (such as water spray, wind monitoring, soil fixatives, and visual observation) will be used as needed to prevent the generation of fugitive dust. Air monitoring to assess the airborne spread of contamination will be performed in accordance with the project HASP (PLN-2128). Air monitoring will 
be conducted as needed to ensure that workers are protected from unnecessary exposure to chemical hazards. Personal protective equipment, when required, will be used as specified in the project HASP and as determined by the industrial hygienist present at the task site.

\subsubsection{Earthwork}

The earthwork for this project will be defined as the following:

- Clearing vegetation as required (vegetation is minimal and clearing may be accomplished concurrently with the excavation of contaminated soil)

- $\quad$ Excavating all materials encountered, of every description, for completion of the project as described in "Section 02200-Earthwork" (provided in Attachment 1) and the design drawings (also provided in Attachment 1)

- $\quad$ Managing dust control

- $\quad$ Delivering all contaminated material excavated for completion of the project to an approved treatment and disposal facility

- $\quad$ Backfilling or contouring all excavations and reclaiming all disturbed task area support sites

- Compacting all backfill in accordance with "Section 02200-Earthwork," which is provided in Attachment 1

- $\quad$ Finish grading and grading for surface draining or revegetation in accordance with "Section 02200-Earthwork" and "Section 02486-Revegetation," which are provided in Attachment 1, and the design drawings also provided in Attachment 1.

Earthwork at the STF-02 Gun Range will include backfill with native soil from approved borrow sources on the INL Site, as required. All earthworks will be performed in accordance with "Section 02200-Earthwork," which is provided in Attachment 1 of this document, and the design drawings also provided in Attachment 1.

It is anticipated that a significant volume of soil with lead concentrations below the remediation goal will remain at the site following completion of the remedial action. The berms will be contoured to approximate the surrounding terrain. If the volume of soil remaining in the berms is too great to allow for appropriate contouring to take place to match the surrounding terrain, excess soil from the berm will be consolidated in the EOCR pond following any necessary pond remediation and confirmation sampling followed by contouring and backfilling with native soil to support vegetation.

\subsubsection{Segregation of Lead from Soil}

The segregation of lead from soil will be accomplished by using classical physical separation techniques (i.e., sieving). Copper fragments present in the soil also will be removed during the physical separation of lead from the soil.

The physical separation process of screening the soils may be performed either dry or wet, depending on the type of soil. Free-flowing sandy soils with little oversize material other than spent projectiles such as that found within the walls in the shooting house are amenable to dry screening to recover the bullets in a condition suitable for recycling. The physical sizing process using wet-screening 
techniques provides for deagglomeration of the soil particles while maintaining a dust-free operation and sharp particle-size fraction cuts. Wet screening allows for partitioning of the particulate metal contamination into narrow-size fractions to facilitate effective gravity separation.

\subsubsection{Borrow, Haul, and Stockpile}

Borrow material required for this project is available from borrow sources located at the INL Site. All on-Site borrow sources have been previously determined to be free of contamination. Borrow operations will be performed in accordance with "Section 02200-Earthwork," which is provided in Attachment 1 of this document, and an approved INL Form 450.AP01, "INEEL Gravel/Borrow Source Request Form." An operation will be established at the borrow area to gather and stockpile the material in preparation for a hauling operation to move the material from the borrow source to the project site for emplacement.

Equipment used for the haul and stockpile operations will remain outside the contamination work areas. The work will require the services of heavy earthwork equipment (such as scrapers, dozers, loaders, and large dump trucks). The work also will require upfront planning and coordination with other site operations and personnel to ensure safe and productive hauling across Site roads. The project will be responsible for maintaining the Site haul roads during operations and for returning haul roads to their original condition. If necessary, a traffic management plan will be prepared, including documentation of the condition of the haul roads prior to operations.

\subsubsection{Contaminated Soil Hauling}

Contaminated soil will be hauled to the disposal facility in either end-dump trucks or roll-on/roll-off containers with an anticipated capacity of $9.2 \mathrm{~m}^{3}\left(12 \mathrm{yd}^{3}\right)$ or greater. It is anticipated that any soil generated will be transported in exclusive-use, closed-transport vehicles.

Hauling may occur concurrently from different locations, provided the buddy system remains in effect and the crew is large enough to support the operations, as determined by the field team leader, health and safety officer, and/or job-site supervisor. Each dump truck or roll-on/roll-off container will have a locking tailgate with a gasket or another mechanism to prevent loss of soil during transport. The driver will inspect the tailgate before and after loading to ensure that it is properly latched. The dump truck or roll-on/roll-off container will have a new plastic liner installed for each load to mitigate the spread of contamination and provide a means of dust control during transportation and disposal. Loads will be covered with a tight-fitting tarp to prevent loss of material during transport. Environmental personnel will evaluate and approve the cover before initial use and throughout the duration of the project.

After loading and before leaving the area, the driver will visually inspect each truck or roll-on/roll-off container to ensure that the exterior is not contaminated. Before leaving the area and under the direction of the job site supervisor, any discovered external contamination will be removed. After the load has been dumped, the truck or roll-on/roll-off container will be covered with a tarp for the return trip.

\subsubsection{Dust Suppression}

Dust generation will be minimized during excavation, loading, hauling, and dumping by using water truck(s) and/or soil fixatives. As required by the project HASP (PLN-2128), air-monitoring results will help determine the adequacy of the dust-suppression methods. Over application of water resulting in free liquids will not be allowed, because additional requirements would be imposed for handling liquid waste. A water-fill station is available at CFA and fire hydrants are available at other facilities, provided 
an outage request is processed. Filling at a fire hydrant requires the use of an attaching gate valve and fire hose approved by the project manager and/or designee to ensure compatibility.

Work will be restricted or suspended if unacceptable amounts of dust are being generated, as determined by the field team leader and/or health and safety officer. This dust could be a result of dry soil, which might require wetting, or a result of wind. All excavating, loading, hauling, and dumping operations will be suspended when sustained wind speed or gusts, as reported by the INL National Oceanic and Atmospheric Administration weather station, exceed established levels of $25 \mathrm{mph}$ sustained with gusts exceeding $35 \mathrm{mph}$. Several partial or full days are anticipated to be lost because of high wind. Work areas that have the potential of generating dust will require water spraying at the end of each workday and other occasions, as deemed necessary by the field team leader and/or health and safety officer.

\subsubsection{Reclamation Seeding}

Upon completion of all earthwork activities, reclamation seeding will take place on the lay-down area and all areas affected by the remediation activities, including material borrowing and stockpiling. The seeding and mulching of these sites will be performed in accordance with the requirements delineated in "Section 02486-Revegetation," which is provided in Attachment 1 to this document.

\subsubsection{Demobilization}

After the remedial action activities have been satisfactorily completed and all equipment has been properly decontaminated, task-site personnel will demobilize and the equipment will be removed from the site. Decontamination pads and temporary fencing erected in support of the activities described herein will be removed and packaged or disposed of appropriately.

\subsection{Summary of Site Activities}

The construction specifications provided in Attachment 1 outline the details of the work to be conducted in support of the OU 10-04 Phase III remedial action. Figure 1-3 provides a general description of the site. Following confirmation that the RAOs have been achieved for the site, the site will be revegetated, as necessary.

\subsection{Field Oversight}

The DOE-ID remediation project manager will be responsible for notifying the EPA and DEQ about project activities. The project manager also will serve as the single interface point for all routine contact between the Agencies and the Contractor. In addition, the Contractor will provide support services for field oversight, health and safety, environmental, quality assurance, and landlord services for this project. An organization chart and position descriptions are provided in the project HASP (PLN-2128).

\subsubsection{Protocol and Coordination of Field Oversight}

The DOE-ID will notify the EPA and DEQ WAG managers of pending remedial action activities (such as project startup, closeout, and inspections). Activities related to preliminary inspections, the prefinal inspection, and the final inspection (if deemed necessary) will be provided to the EPA and DEQ WAG managers a minimum of 14 calendar days prior to commencement of the activity. 
Visitors to any of the project sites who wish to observe activities must meet badging and training requirements necessary to enter INL facilities. Training requirements for visitors are described in the project HASP (PLN-2128).

\subsection{Project Cost Estimate}

Table 5-1 presents the project cost estimates for the tasks addressed by this Phase III RD/RA Work Plan. The costs may be revised during subsequent submittals of this document to reflect the most current estimate, based on comments to the design and other data. 
Table 5-1. Phase III project cost estimate.

\begin{tabular}{|c|c|c|}
\hline Description & $\begin{array}{c}\text { Cost }(\$) \\
\text { (Net Present Value) }\end{array}$ & $\begin{array}{c}\text { Totals } \\
(\$)\end{array}$ \\
\hline Capital Costs & & $2,304,200$ \\
\hline Remedial Design & $\underline{143,200}$ & - \\
\hline Remedial Design/Remedial Action Statement of Work & 11,000 & - \\
\hline Remedial Design/Remedial Action Work Plan & 81,000 & - \\
\hline Hazards and safety analysis documentation & 3,800 & - \\
\hline Sampling and Analysis Plan & 3,900 & - \\
\hline Operations and Maintenance Plan & 4,200 & - \\
\hline Health and Safety Plan & 4,600 & - \\
\hline Plans and construction specifications & 26,300 & - \\
\hline Waste Management Plan & 2,000 & - \\
\hline Miscellaneous environmental documentation & 6,400 & - \\
\hline Remediation Support & $\underline{146,000}$ & - \\
\hline Quality assurance & 22,000 & - \\
\hline Project office operations & 124,000 & - \\
\hline Remediation/Technical Support Activities & $\underline{42,000}$ & - \\
\hline Engineering and technical support & 42,000 & - \\
\hline Remedial Action & $\underline{1,929,000}$ & - \\
\hline Mobilization and preparatory work & 12,000 & - \\
\hline Site work & $1,880,000$ & - \\
\hline Site restoration & 8,000 & - \\
\hline Demobilization & 12,000 & - \\
\hline Other & 17,000 & - \\
\hline Removal Action & $\underline{44,000}$ & - \\
\hline Remedial Action Report & 44,000 & - \\
\hline Operations Cost & $\mathrm{NA}^{\mathrm{a}}$ & - \\
\hline General and Administrative & - & 44,000 \\
\hline SUBTOTAL COSTS & - & $2,348,200$ \\
\hline Plus $30 \%$ contingency & - & 704,500 \\
\hline TOTAL PROJECT COST IN NET PRESENT VALUE & - & $3,052,700$ \\
\hline \multicolumn{3}{|c|}{$\begin{array}{l}\text { a. It is anticipated that all contaminated materials exceeding the remedial action objectives will be removed, thereby } \\
\text { negating the need for any operations and maintenance activities. }\end{array}$} \\
\hline \multicolumn{3}{|c|}{$\begin{array}{l}\text { Note: Net present value is the cumulative worth of all costs, as of the beginning of the first year of activities (i.e., FY 2004) } \\
\text { accounting for inflation of future costs. Net present values are estimated assuming variable annual inflation factors for the } \\
\text { first } 10 \text { years-in accordance with DOE Order } 430.1 \text { B, "Real Property Asset Management"-- followed by a constant } \\
5 \% \text { annual inflation rate. A constant } 5 \% \text { discount rate is assumed. }\end{array}$} \\
\hline $\begin{array}{l}\text { DOE }=\text { U.S. Department of Energy } \\
\text { FY = fiscal year } \\
\text { NA = not applicable }\end{array}$ & & \\
\hline
\end{tabular}




\subsection{Project Schedule}

The schedule for Phase III of the OU 10-04 RD/RA is presented in Table 5-2. The schedule covers all Phase III project tasks identified in the OU 10-04 RD/RA Scope of Work (DOE-ID 2003) through completion of the Phase III remedial action report. Administrative and document preparation activities are based upon an 8-hour day, 5-day workweek, while field activities are based upon a 10-hour day, 4-day workweek. The schedule does not include any contingency for delay because of late or slow document reviews or for field activities experiencing loss of productivity because of adverse weather conditions or other causes outside the project team's control.

\subsection{Inspections}

Periodic inspections can occur at any time during the remediation activities. Upon completion of remediation activities but prior to demobilization, a standard prefinal inspection will be performed at the site at the discretion of the project managers or designees. The prefinal inspection may be performed prior to revegetation of the site given that completion of all other remediation activities (i.e., excavation, contouring, and sampling) may occur prior to the specified timeframes for reseeding. The prefinal inspection will be conducted to document the status of all project work elements. If determined to be necessary by concurrence of the Agencies, a final inspection may be performed to assess whether deficiencies identified during the prefinal inspection have been adequately addressed. The inspections will establish compliance with this RD/RA Work Plan and all requirements indicated. 
Table 5-2. Remedial action schedule.

\begin{tabular}{lccc}
\hline \multicolumn{1}{c}{ Activity } & $\begin{array}{c}\text { Start } \\
\text { Date }\end{array}$ & $\begin{array}{c}\text { Completion } \\
\text { Date }\end{array}$ & $\begin{array}{c}\text { Enforceable } \\
\text { Date }\end{array}$ \\
\hline Draft RD/RA Scope of Work sent to the Agencies for review & $10 / 01 / 2002$ & $11 / 10 / 2002$ & - \\
RD/RA Scope of Work finalized & $11 / 10 / 2002$ & $01 / 27 / 2003$ & - \\
Draft Phase III RD/RA Work Plan prepared & $10 / 01 / 2004$ & $04 / 29 / 2005$ & $04 / 30 / 2005$ \\
Agency review of the Draft Phase III RD/RA Work Plan & $05 / 02 / 2005$ & $06 / 15 / 2005$ & - \\
Agency comments on Draft Phase III RD/RA Work Plan due & - & $06 / 15 / 2005$ & - \\
Resolution of Draft Phase III RD/RA Work Plan comments & $06 / 16 / 2005$ & $07 / 29 / 2005$ & - \\
Draft Final Phase III RD/RA Work Plan sent to the Agencies & $08 / 01 / 2005$ & $08 / 31 / 2005$ & - \\
Phase III RD/RA Work Plan finalized & $09 / 01 / 2005$ & $09 / 30 / 2005$ & - \\
Phase III RD/RA Work Plan revised & $09 / 01 / 2006$ & $09 / 30 / 2006$ & - \\
Phase III remedial action fieldwork & & - \\
Phase III prefinal inspection & $10 / 09 / 2006$ & $05 / 01 / 2007$ & - \\
& $04 / 15 / 2007$ & $04 / 22 / 2007$ & - \\
Draft Phase III Remedial Action Report prepared & & & - \\
Draft Phase III Remedial Action Report submitted to the Agencies & - & $10 / 31 / 2007$ & $08 / 31 / 2018$ \\
Agency review of the Draft Phase III Remedial Action Report & $11 / 01 / 2007$ & $12 / 14 / 2007$ & - \\
Agency comments on the Draft Phase III Remedial Action Report & - & $12 / 14 / 2007$ & - \\
due & & & - \\
Resolution of the Draft Phase III Remedial Action Report & $12 / 17 / 2007$ & $02 / 04 / 2008$ & - \\
comments & & & - \\
Draft Final Phase III Remedial Action Report sent to the Agencies & $02 / 05 / 2008$ & $03 / 03 / 2008$ & - \\
Phase III Remedial Action Report finalized & $03 / 04 / 2008$ & $04 / 15 / 2008$ & - \\
\hline a. An allowance will be made for shutdown of field activities during the winter months. & & & - \\
RD/RA = remedial design/remedial action & & & - \\
\hline
\end{tabular}

\subsubsection{Prefinal Inspection}

The Agency project managers or their designees will conduct the prefinal inspection before completion of the remedial action. The DOE-ID will notify the Agencies approximately 2 weeks before the prefinal inspection date. This inspection will determine the status of the remediation activities, including outstanding requirements and actions necessary to resolve any identified issues. During the inspection, the Agencies will identify and approve all of the outstanding requirements along with the actions required to resolve them. The prefinal inspection report will document any unresolved items and the actions required for resolution. In some instances, the prefinal inspections can be performed as each major element of the project is completed, rather than at the time of total completion.

A checklist used to document the prefinal inspection will be developed and implemented upon approval by the Agencies. The action for resolution and the anticipated schedule of completion will be noted next to the outstanding items and documented on the prefinal inspection checklist. 


\subsubsection{Prefinal Inspection Report}

Documentation of the prefinal inspection will be provided in a prefinal inspection report that will contain the following elements:

- $\quad$ The names of all inspection participants

- $\quad$ The inspection checklist(s) containing specific project elements and areas to be inspected to constitute acceptance of the remediation activities

- A discussion of all documented inspection findings

- $\quad$ Corrective actions to be taken to correct deficiencies identified in the inspections, including the required corrective action, acceptance criteria or standards, and planned dates for completion of the actions

- $\quad$ A date for the final inspection, if necessary.

The prefinal inspection report will be issued to indicate the objectives of the OU 10-04 ROD (DOE-ID 2002) are being met. The prefinal inspection report will not be revised/finalized. The inspection will be finalized in the remedial action report documenting the prefinal inspection process. The completed prefinal inspection checklist may be included as an appendix to the remedial action report in accordance with Section 8.4 of the Federal Facility Agreement and Consent Order for the Idaho National Engineering Laboratory (DOE-ID 1991). Submittal of the prefinal inspection report and the respective targeted schedule are identified in Section 5.8, "Inspections."

\subsubsection{Final Inspection}

If deemed necessary, the final inspection will be conducted following demobilization, after all excess materials and nonessential remediation equipment have been removed from the site and remediation of the site is considered complete. Some equipment may remain onsite to repair items identified during final inspections. Final inspections, as conducted by the Agencies' project managers or their designees, will confirm the resolution of all outstanding items identified in the prefinal inspection and verify that the OU 10-04 Phase III remedial action has been completed in accordance with the requirements of the OU 10-04 ROD (DOE-ID 2002). Final inspections will be documented in the remedial action report.

\subsection{Remedial Action Sampling and Analysis Plan}

The Field Sampling Plan for the Operable Units 6-05 and 10-04 Remedial Action, Phase III (DOE-ID 2006a) is comprised of two parts: the field sampling plan and the quality assurance project plan. These plans have been prepared pursuant to the "National Oil and Hazardous Substances Pollution Contingency Plan" (40 CFR 300), consistent with the EPA policy on the preparation of sampling and analysis plans and in accordance with internal company procedures. The Field Sampling Plan for the Operable Units 6-05 and 10-04 Remedial Action, Phase III (DOE-ID 2006a) describes the field sampling activities that will be performed, while the Quality Assurance Project Plan details the process and programs that will be used to ensure that the data generated are suitable for their intended purposes. The governing quality assurance project plan for this sampling effort will be the Quality Assurance Project Plan for Waste Area Groups 1, 2, 3, 4, 5, 6, 7, 10, and Deactivation, Decontamination, and Decommissioning (DOE-ID 2006b), which is incorporated into the Field Sampling Plan by reference. 
Work control processes will follow formal practices in accordance with communicated agreement with the appropriate site area directors and the project manager for the Miscellaneous Sites Cleanup Project.

\subsection{Health and Safety Plan}

A site-specific HASP (PLN-2128) has been prepared for the tasks and conditions to be encountered during this project. The HASP is a living document and may be updated as conditions dictate. The HASP covers the following items:

- Task-site responsibility

- $\quad$ Personnel training

- $\quad$ Occupational Medical Program and medical surveillance

- $\quad$ Accident Prevention Program

- $\quad$ Site control and security

- $\quad$ Hazard evaluation

- $\quad$ Personal protective equipment (PPE)

- Decontamination

- $\quad$ Emergency response plan for the task sites.

\subsection{Waste Minimization Plan}

Waste will be generated as a result of the activities conducted during this project. The types of waste expected to be generated include, but are not limited to, the following:

- $\quad$ PPE

- $\quad$ Equipment decontamination liquid residue

- Equipment decontamination solid residue

- $\quad$ Plastic sheeting

- $\quad$ Excavated, contaminated soil

- $\quad$ Removed vegetation to be disposed of with the excavated, contaminated soil

- $\quad$ Air monitoring filters

- Unused/unaltered sample material

- $\quad$ Analytical residues

- $\quad$ Sample containers

- Hydraulic spills

- $\quad$ Miscellaneous waste.

Waste could be hazardous. As remediation continues, additional waste streams could be identified. All waste streams are required to have the waste identified and characterized. The appropriate waste management organization (e.g., Waste Generator Services) will complete and approve hazardous waste 
determinations prior to or at the time of generation. A description of the types of waste anticipated to be generated and the proposed disposition route is provided in Appendix B, "Waste Management Plan."

\subsection{Work within the Floodplain}

The STF-02 Gun Range is outside the hypothetical 100-year floodplain of the Big Lost River, as described in the Flood Routing Analysis for a Failure of Mackay Dam (INEL 1986).

\subsection{Decontamination Plan}

Equipment decontamination will be conducted at the task site where contaminated materials will be encountered. A decontamination area will be established such that the potential for downwind contamination from the remediation site is mitigated. Decontamination operations will be performed in accordance with the requirements set forth in the project HASP (PLN-2128).

Dry decontamination procedures will be used at the beginning of the decontamination effort. If these procedures are not successful, the equipment will be moved onto a clean decontamination pad or plastic and sprayed with a high-pressure water spray from a portable unit. All equipment will then be surveyed and visually inspected to ensure that all source contamination has been removed. If additional decontamination is required, further decontamination efforts will be conducted until the equipment is clean and may be released. The equipment will remain in the area where remediation is occurring until it is adequately decontaminated, as verified by field surveillance methods.

Management of waste generated during decontamination efforts will remain within the area of contamination for temporary storage until final waste disposition. Tools used for equipment decontamination will be decontaminated, surveyed for contamination, and released for reuse.

\subsection{Spill Prevention/Response Program}

Any inadvertent spill or release of potentially hazardous materials will be subject to the substantive requirements contained in "Emergency Management" (PLN-114). Handling of the materials and/or substance will be performed in accordance with the recommendations of the applicable material safety data sheets, which will be located onsite. In the event of a spill, the emergency response plan (see Section 10 in the project HASP [ICP 2005]) will be activated. All materials/substances on the work site will be stored in accordance with the applicable regulations and in approved containers.

\subsection{Operations and Maintenance Plan}

The "Operations and Maintenance Plan for Operable Units 6-05 and 10-04, Phase III" (provided in Appendix D) describes the long-term O\&M activities that will be conducted in support of the OU 10-04 Phase III activities to ensure that the selected remedy identified in the OU 10-04 ROD (DOE-ID 2002) remains protective of human health and the environment. The plan outlines the ongoing maintenance activities and inspection requirements for the Phase III remediated area. The plan is a living document, revised as necessary to incorporate changes and additions identified during implementation of the plan. Long-term O\&M should not be required at the site following completion of the remedial action, since the selected remedy provides for the removal of the contaminated media. The site is included under the INL Sitewide institutional controls inspection and reporting requirements until such time as the remediation is completed. If contamination exceeding the allowable concentration for free-release remains following all efforts to remediate the site, the site will remain under institutional control. This event will be documented in the final remedial action report. 
The INL Sitewide Institutional Controls Plan (DOE-ID 2006c) outlines the institutional control requirements for INL CERCLA sites, including WAG 10. Land use will be restricted at the STF-02 Gun Range until remediation is implemented as prescribed in the OU 10-04 ROD (DOE-ID 2002); then, based on analysis of residual risk, potential land use will be determined. Land-use control will not be required after remediation if all contaminated soil above the remediation goal is removed. As determined by post remediation risk analysis, land-use restrictions will be established and maintained as required for areas that potentially pose a threat from lead remaining on the site. Institutional controls will be maintained until residual risk is removed or reduced to acceptable levels based on the results of a 5-year review. The DOE-ID will notify the EPA and State of Idaho before any transfer, sale, or lease to a nonfederal entity (such as a state or local government or a private person) of the site. This site will be subject to 5-year reviews with restrictions remaining until 2095 or until determined to be unnecessary during the 5-year reviews.

\subsection{Remedial Action Report}

The Phase III remedial action report will be prepared following demobilization and restoration of the site and submitted to the Agencies as a primary document. The remedial action report will include, but not be limited to, the following:

- Identification of the work defined in this Phase III RD/RA Work Plan and certification that the work was performed.

- $\quad$ Explanation of any modifications to the Phase III RD/RA Work Plan.

- Any modifications made to the remedial design during the remedial action phase, including the purpose and results of the modifications.

- $\quad$ Problems encountered during the remedial action and resolutions to these problems.

- $\quad$ Any outstanding items from the prefinal inspection checklist that were identified and described. In responding to comments received, the prefinal inspection checklist will not be revised; rather, it will be finalized in the context of the remedial action report.

- Certification that the remedy is operational and functional. The DOE-ID will provide a statement certifying that the remedies are achieving, or have achieved, the requirements of the OU 10-04 ROD (DOE-ID 2002).

- As-built drawings showing final contours.

- $\quad$ Final total costs of the remedial action for Phase III activities.

- $\quad$ Results of the Phase III final inspection(s). Any final inspection will be documented in the draft remedial action report, submitted to the Agencies' project managers within 60 calendar days of the final inspection, and used to resolve prefinal inspection issues. 


\section{FIVE-YEAR REVIEW}

In accordance with the "National Oil and Hazardous Substances Pollution Contingency Plan" (40 CFR 300), a statutory review of the selected remedy will be conducted no less than every 5 years for sites where contamination above the risk-based concentrations is left in place. A 5-year review should not be necessary at the STF-02 Gun Range following the completion of the remedial action, as contamination exceeding the RAOs will be removed. The site will be included in any Sitewide 5-year reviews performed prior to finalization of the Phase III remedial action report. In the event that contamination above these concentrations remains at a given site, a 5-year review will evaluate the remedy to determine if it remains protective of human health and the environment. The 5-year reviews will be conducted for remediated sites with institutional controls until the year 2095 at a minimum (i.e., until the 100-year institutional control period expires) or until it is determined during a 5-year review that controls and reviews are no longer necessary. 
6-2 


\section{REFERENCES}

36 CFR 800.4, 2004, "Identification of Historic Properties," Code of Federal Regulations, Office of the Federal Register, August 2004.

36 CFR 800.5, 2004, “Assessment of Adverse Effects," Code of Federal Regulations, Office of the Federal Register, August 2004.

40 CFR 63.543, 2006, "Standards for Process Sources," Code of Federal Regulations, Office of the Federal Register, July 2006.

40 CFR 122.26, 2006, "Storm Water Discharges (Applicable to State NPDES Programs, see $\S 123.25$ )," Code of Federal Regulations, Office of the Federal Register, June 2006.

40 CFR 261.1, 2006, "Purpose and Scope," Code of Federal Regulations, Office of the Federal Register, August 2006.

40 CFR 261.2, 2006, "Definition of Solid Waste," Code of Federal Regulations, Office of the Federal Register, August 2006.

40 CFR 261.6, 2006, "Requirements for Recyclable Materials," Code of Federal Regulations, Office of the Federal Register, August 2006.

40 CFR 262.11, 2006, "Hazardous Waste Determination," Code of Federal Regulations, Office of the Federal Register, July 2006.

40 CFR 264.1, 2006, "Purpose, Scope, and Applicability," Code of Federal Regulations, Office of the Federal Register, July 2006.

40 CFR 264.114, 2006, "Disposal or Decontamination of Equipment, Structures, and Soils," Code of Federal Regulations, Office of the Federal Register, July 2006.

40 CFR 264.171, 2006, "Condition of Containers," Code of Federal Regulations, Office of the Federal Register, July 2006.

40 CFR 264.172, 2006, "Compatibility of Waste with Containers," Code of Federal Regulations, Office of the Federal Register, July 2006.

40 CFR 264.173, 2006, "Management of Containers," Code of Federal Regulations, Office of the Federal Register, July 2006.

40 CFR 264.174, 2006, "Inspections," Code of Federal Regulations, Office of the Federal Register, July 2006.

40 CFR 264.175, 2006, "Containment," Code of Federal Regulations, Office of the Federal Register, July 2006.

40 CFR 264.176, 2006, "Special Requirements for Ignitable or Reactive Waste," Code of Federal Regulations, Office of the Federal Register, July 2006. 
40 CFR 264.177, 2006, "Special Requirements for Incompatible Wastes," Code of Federal Regulations, Office of the Federal Register, July 2006.

40 CFR 264.554, 2006, "Staging Piles," Code of Federal Regulations, Office of the Federal Register, July 2006.

40 CFR 268.40, 2006, “Applicability of Treatment Standards," Code of Federal Regulations, Office of the Federal Register, July 2006.

40 CFR 268.45, 2006, “Treatment Standards for Hazardous Debris," Code of Federal Regulations, Office of the Federal Register, July 2006.

40 CFR 268.48, 2006, "Universal Treatment Standards," Code of Federal Regulations, Office of the Federal Register, July 2006.

40 CFR 268.49, 2006, “Alternative LDR Treatment Standards for Contaminated Soil," Code of Federal Regulations, Office of the Federal Register, July 2006.

40 CFR 300, 2006, "National Oil and Hazardous Substances Pollution Contingency Plan," Code of Federal Regulations, Office of the Federal Register, August 2006.

43 CFR 10.6, 2006, “Custody,” Code of Federal Regulations, Office of the Federal Register, April 2006.

43 CFR 10.10, 2006, "Repatriation," Code of Federal Regulations, Office of the Federal Register, April 2006.

16 USC $\S 470$ h-2 et seq., 2005, "Historic Properties Owned or Controlled by Federal Agencies," United States Code, January 3, 2005.

25 USC § 3002 et seq., 2004, “Ownership,” United States Code, January 19, 2004.

25 USC § 3005 et seq., 2004, “Repatriation,” United States Code, January 19, 2004.

42 USC § 6901 et seq., 1976, "Resource Conservation and Recovery Act (Solid Waste Disposal Act)," United States Code, October 21, 1976.

42 USC $\S 9601$ et seq., 1980, "Comprehensive Environmental Response, Compensation and Liability Act of 1980 (CERCLA/Superfund)," United States Code, December 11, 1980.

DOE M 232.1-1A, 2004, "Environment, Safety, and Health Reporting Manual," Change 1, U.S. Department of Energy, September 9, 2004.

DOE M 232.1-2, 2003, "Occurrence Reporting and Processing of Operations Information," U.S. Department of Energy, August 19, 2003.

DOE O 414.1C, 2005, “Quality Assurance,” U.S. Department of Energy, June 17, 2005.

DOE O 430.1B, 2003, "Real Property Asset Management," U.S. Department of Energy, September 24, 2003.

DOE O 440.1A, 1998, "Worker Protection Management for DOE Federal and Contractor Employees," U.S. Department of Energy, March 27, 1998. 
DOE O 450.1, 2005, "Environmental Protection Program," Change 1, U.S. Department of Energy, January 15, 2005.

DOE O 460.1B, 2003, "Packaging and Transportation Safety,” U.S. Department of Energy, April 4, 2003.

DOE O 5480.4, 1993, "Environmental Protection, Safety, and Health Protection Standards," Change 4, U.S. Department of Energy, January 7, 1993.

DOE O 5480.19, 2001, “Conduct of Operations Requirements for DOE Facilities," Change 2, U.S. Department of Energy, October 23, 2001.

DOE-ID, 1991, Federal Facility Agreement and Consent Order for the Idaho National Engineering Laboratory, Administrative Docket No. 1088-06-120, U.S. Department of Energy Idaho Operations Office; U.S. Environmental Protection Agency, Region 10; Idaho Department of Health and Welfare, December 9, 1991.

DOE-ID, 2005, Idaho National Laboratory Cultural Resource Management Plan, DOE/ID-10997, Rev. 1, U.S. Department of Energy Idaho Operations Office, September 2005.

DOE-ID, 2001, Comprehensive Remedial Investigation/Feasibility Study for Waste Area Groups 6 and 10 Operable Unit 10-04, DOE/ID-10807, Rev. 0, U.S. Department of Energy Idaho Operations Office, August 2001.

DOE-ID, 2002, Record of Decision Experimental Breeder Reactor-I/Boiling Water Reactor Experiment Area and Miscellaneous Sites, Operable Unit 6-05 and 10-04, DOE/ID-10980, Rev. 0, U.S. Department of Energy Idaho Operations Office; U.S. Environmental Protection Agency, Region 10; Idaho Department of Environmental Quality, November 2002.

DOE-ID, 2003, Operable Units 6-05 and 10-04, Experimental Breeder Reactor-I/Boiling Water Reactor Experiment Area and Miscellaneous Sites, Remedial Design/Remedial Action Scope of Work, DOE/ID-11035, Rev. 0, U.S. Department of Energy Idaho Operations Office, February 2003.

DOE-ID, 2006b, Quality Assurance Project Plan for Waste Area Groups 1, 2, 3, 4, 5, 6, 7, 10, and Deactivation, Decontamination, and Decommissioning, DOE/ID-10587, Rev. 9, U.S. Department of Energy Idaho Operations Office, July 2006.

DOE-ID, 2006c, INL Sitewide Institutional Controls Plan, DOE/ID-11042, Rev. 3, U.S. Department of Energy Idaho Operations Office, July 2006.

DOE-ID, 2006a, Field Sampling Plan for the Operable Units 6-05 and 10-04 Remedial Action, Phase III, DOE/NE-ID-11212, Rev. 1, U.S. Department of Energy Idaho Operations Office, August 2006.

EPA, 1988, Guidance for Conducting Remedial Investigations and Feasibility Studies Under CERCLA, Interim Final, EPA/540/G-89/004, U.S. Environmental Protection Agency, October 1988.

EPA, 1994, OSWER 9555.4-12, "Revised Interim Soil Lead Guidance for CERCLA Sites and RCRA Corrective Action Facilities," EPA 540/F-94/043, U.S. Environmental Protection Agency, Office of Solid Waste and Emergency Response, July 14, 1994.

Form 450.AP01, 2004, "INEEL Gravel/Borrow Request," Rev. 0, Idaho National Engineering and Environmental Laboratory, July 2004. 
HAD-329, 2004, "Hazard Assessment Document for the STF-02 Security Training Facility Gun Range Remediation," Rev. 0, Idaho National Engineering and Environmental Laboratory, November 2004.

Hobbes, T. L., to Distribution, April 20, 2004, "Interim Guidance for Less Than Category 3 (LTHC3) Safety Basis Documentation,” TLH-01-04.

PLN-2128, Miscellaneous Sites Cleanup Project Health and Safety Plan, Rev. 1, Idaho Cleanup Project, July 2006.

IDAPA 58.01.01.11, 2002, "Definitions for the Purposes of Sections 790 through 799," Idaho Administrative Procedures Act, Idaho Department of Environmental Quality, March 15, 2002.

IDAPA 58.01.01.161, 1995, “Toxic Substances,” Idaho Administrative Procedures Act, Idaho Department of Environmental Quality, June 30, 1995.

IDAPA 58.01.01.500.02, 1994, “Compliance with Rules and Regulations,” Idaho Administrative Procedures Act, Idaho Department of Environmental Quality, May 1, 1994.

IDAPA 58.01.01.585, 1995, "Toxic Air Pollutants Non-Carcinogenic Increments," Idaho Administrative Procedures Act, Idaho Department of Environmental Quality, June 30, 1995.

IDAPA 58.01.01.586, 2001, “Toxic Air Pollutants Carcinogenic Increments,” Idaho Administrative Procedures Act, Idaho Department of Environmental Quality, March 30, 2001.

IDAPA 58.01.01.650, 1994, "Rules for Control of Fugitive Dust," Idaho Administrative Procedures Act, Idaho Department of Environmental Quality, May 1, 1994.

IDAPA 58.01.01.651, 1994, “General Rules,” Idaho Administrative Procedures Act, Idaho Department of Environmental Quality, May 1, 1994.

IDAPA 58.01.05.005, 2005, “Identification and Listing of Hazardous Waste," Idaho Administrative Procedures Act, Idaho Department of Environmental Quality, April 6, 2005.

IDAPA 58.01.05.006, 2005, "Standards Applicable to Generators of Hazardous Waste," Idaho Administrative Procedures Act, Idaho Department of Environmental Quality, April 6, 2005.

IDAPA 58.01.05.008, 2005, "Standards for Owners and Operators of Hazardous Waste Treatment, Storage, and Disposal Facilities," Idaho Administrative Procedures Act, Idaho Department of Environmental Quality, April 6, 2005.

IDAPA 58.01.05.011, 2005, "Land Disposal Restrictions," Idaho Administrative Procedures Act, Idaho Department of Environmental Quality, April 6, 2005.

IDAPA 58.01.11.200, 1997, "Ground Water Quality Standards," Idaho Administrative Procedures Act, Idaho Department of Environmental Quality, March 20, 1997.

INEEL, 2000, Field Sampling Plan for Operable Unit 10-04 Security Training Facility Gun Range (Final), INEEL/EXT-99-00737, Rev. 1, Idaho National Engineering and Environmental Laboratory, March 2000. 
INEL, 1986, Flood Routing Analysis for a Failure of Mackay Dam, EGG-EP-7184, Idaho National Engineering Laboratory, June 1986.

MCP-540, 2006, “Assigning Quality Levels,” Rev. 16, Manual 10A-Engineering, Idaho Cleanup Project, May 2006.

PDD-1029, 2006, "Pollution Prevention Program,” Rev. 2, Manual 17-Waste Management, Idaho Cleanup Project, June 2006.

PLN-114, 2005, "Emergency Management," Rev. 24, Manual 16A-Emergency Preparedness Base Plan, Idaho National Laboratory, June 2005.

PLN-2087, 2006, "Project Execution Plan for the Miscellaneous Sites Cleanup," Rev. 2, Idaho Cleanup Project, July 2006. 
Appendix A

\section{Air Emissions Analysis for Excavation of Lead-Contaminated Soils at the STF-02 Gun Range}


A-2 


\title{
Air Modeling Analysis for STF-02 Gun Range Remediation
}

\author{
C. S. Staley \\ BBWI Applied Geosciences
}

December 2004

\section{INTRODUCTION}

The Idaho Cleanup Project (ICP) is planning to remediate the Security Training Facility (STF)-02 Gun Range on the Idaho National Laboratory (INL). Remediation consists of removing and safely disposing of gun range soils, earthen berms around the gun range, pond soils, and the "shooting house." In most cases, the soils are contaminated with low levels of metals. This report examines potential air quality impacts on downwind receptors from these removal activities.

\section{METHODS/ASSUMPTIONS}

\section{Source Term}

Soil sampling data provided by the ICP was used to develop the source term for modeling downwind concentrations of metals. Data from 38 soil samples from the berms and two samples from the pond bottom were used as a starting point. Results from the berms were used in this analysis for the gun range soils per direction from the ICP.

Soil sampling results were compared with INL background levels (Table A-1). Background levels used were those collected for the New Production Reactor Project (Rood, Harris, and White 1995). For the 38 berm samples, only those metals with averages exceeding the average background concentration were included for air modeling. For the two pond bottom samples, results were compared with the mean plus one standard deviation for the background samples; if the maximum pond sample exceeded the mean plus one standard deviation for background samples, that metal was included for modeling. For those metals that passed this screening and were therefore modeled, the average value was used for berm samples and the maximum for pond samples.

The release rates for the metals, in $\mathrm{lb} /$ hour, were calculated based on the anticipated duration of the project and the relative volumes of soil to be removed from the two areas (berms plus the gun range - referred to hereafter as "berms"- and the pond bottom). The project is expected to extend over portions of 3 years from fall 2009 to summer 2011 with work suspended during the winter months. The longest, continuous work would be for 7 months in 2010; for conservatism, it is assumed that the entire project is completed in those 7 months. The volumes of soil to be removed are $14,870 \mathrm{~m}^{3}$ and $405 \mathrm{~m}^{3}$ from the berms and pond, respectively. Apportioning the working hours in 7 months (about 1,210 hours) by the relative soil volumes gives 1,178 hours for the berms and 32 hours for the pond. Other assumptions for release calculations are soil density $=1.5 \mathrm{~g} / \mathrm{cc}$ and release fraction of material handled $=0.001$ (from Appendix D of 40 CFR 61 - for particulate solids). This fraction is very conservative and can be compared to the U.S. Environmental Protection Agency's (EPA's) AP-42 release fraction for sand and gravel processing operations, "active storage piles," of $0.21 \mathrm{~kg}$ particulate resuspended per $\mathrm{Mg}$ material handled or 2.1E-04 (EPA 1995). The equation for release of a metal is: 
$R R_{i}=\left(C_{i} \times M_{s} \times R F \times C F\right) \div T$.

Where:

$$
\begin{aligned}
& \mathrm{RR}_{\mathrm{i}}=\text { release rate of metal } \mathrm{i} \text { in } \mathrm{lb} / \mathrm{hr} \\
& \mathrm{C}_{\mathrm{i}}=\text { concentration of metal } \mathrm{i} \text { in soil in } \mathrm{mg} / \mathrm{kg} \\
& \mathrm{M}_{\mathrm{s}}=\text { mass of soil in } \mathrm{kg} \\
& \mathrm{RF}=\text { release fraction }=0.001 \\
& \mathrm{CF}=\text { conversion factor, } \mathrm{mg} \text { to } \mathrm{g} \text { and } \mathrm{g} \text { to } \mathrm{lb}=1 / 454000 \\
& \mathrm{~T}=\text { time required for excavation, in hours. }
\end{aligned}
$$

For air dispersion modeling, releases are further averaged over the averaging time for each metal (Tables A-2 and A-3) to account for noncontinuous remediation activity. For example, RR for arsenic (which has an annual averaging time) from berms is multiplied by (1178/8766) or the number of hours of excavation in 1 year divided by the total hours in the year.

Calculated release rates, in $\mathrm{lb} /$ hour, were compared with State of Idaho emission limits for toxic air pollutants (Tables A-2 and A-3). Those emissions exceeding emission limits were then modeled for downwind concentrations and compared to Idaho air concentration limits - acceptable ambient concentrations (AACs) and acceptable ambient concentration for carcinogen (AACCs). For lead, there is no AAC or AACC; instead, the significance limit for Permits to Construct was applied. That limit is $0.1 \mu \mathrm{g} / \mathrm{m}^{3}$.

\section{Air Dispersion Modeling}

Air dispersion of metal emissions was modeled using EPA's SCREEN3 code. This code - as the name implies - is a screening code and, as such, is quite conservative. Air concentrations were modeled in two locations: for noncarcinogenic toxic air pollutants with 24-hour average limits (AACs), air concentrations were modeled to the nearest ambient air location, a point on U.S. Highway 20, 1,708 $\mathrm{m}$ from the gun range. For carcinogenic toxic air pollutants with annual average AACCs, as well as for lead with a quarterly average limit, concentrations were modeled to the nearest INL boundary, 8,131 m away (Figure 1). The SCREEN3 output is a 1-hour average, which must be adjusted for longer averaging times using persistence factors; these factors account for plume meander. Persistence factors used were 0.4 for 24-hour averaging, 0.13 for quarterly averaging, and 0.125 for annual averaging (DEQ 2002). The SCREEN3 output file is attached as Appendix A-1.

\section{RESULTS}

Modeled air concentrations are compared with appropriate limits in Table A-4. All metal concentrations, which are considered conservative estimates, are below their respective air quality limits. 


\section{REFERENCES}

40 CFR 61, 2005, "National Emission Standards for Hazardous Air Pollutants," Code of Federal Regulations, Office of the Federal Register, March 2005.

DEQ, 2002, State of Idaho Air Quality Modeling Guideline, Doc. ID AQ-011, Rev. 1, Air Quality Division, Stationary Source Program, December 2002.

EPA, 1995, Sand and Gravel Processing, Final Report, Section 11.19.1 in Emission Factor Documentation for AP-42, EPA Office of Air Quality Planning and Standards, Emission Factor and Inventory Group, April 1995.

Rood, S. M., G. A. Harris, and G. J. White, 1995, Background Dose Equivalent Rates and Surficial Soil Metal and Radionuclide Concentrations for the Idaho National Engineering Laboratory, INEL-94/0250, Rev. 0, Idaho National Engineering Laboratory, February 1995. 


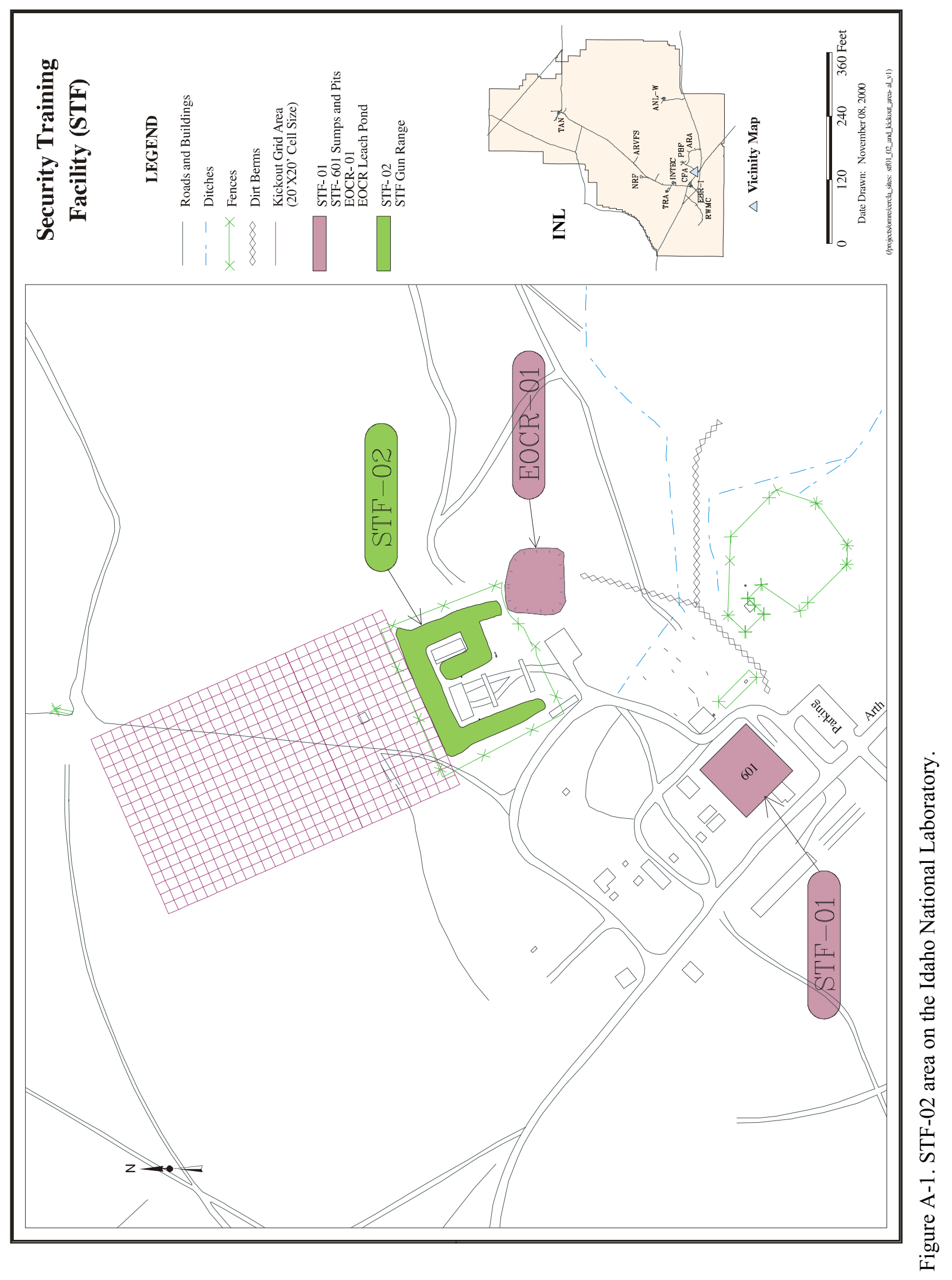

A-6 


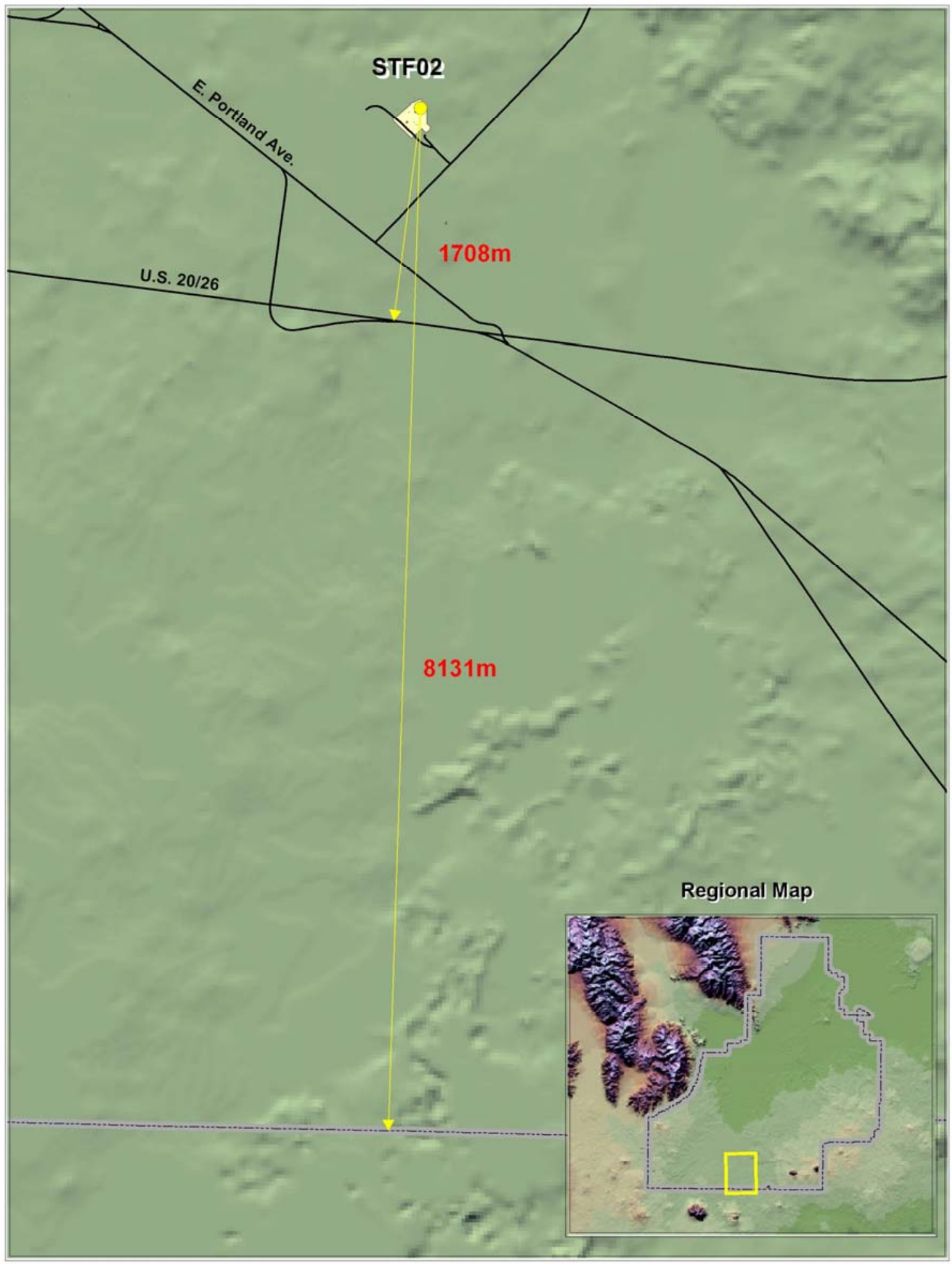

Figure A-2. Location of the STF-02 and distances to receptors. 


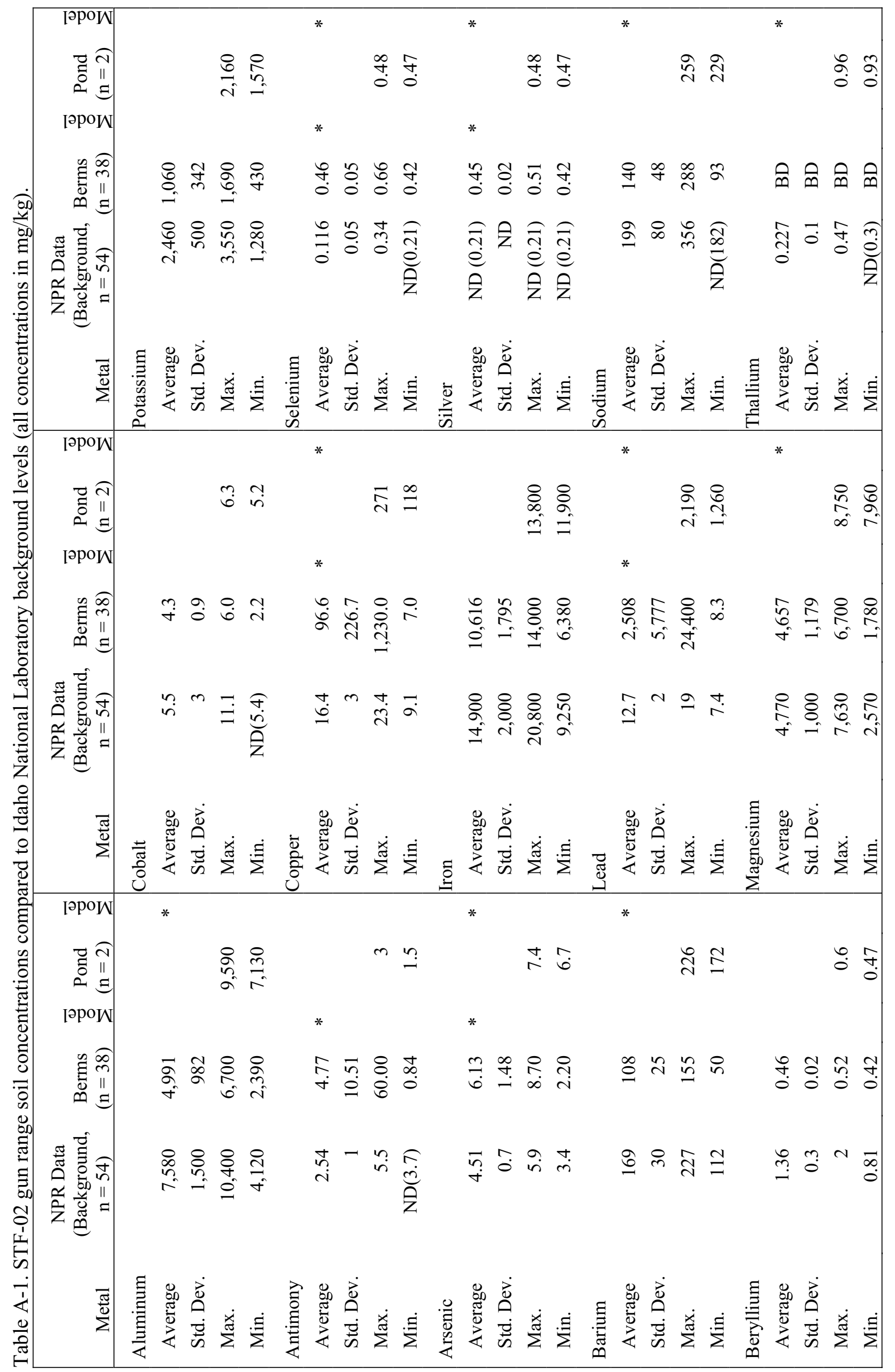




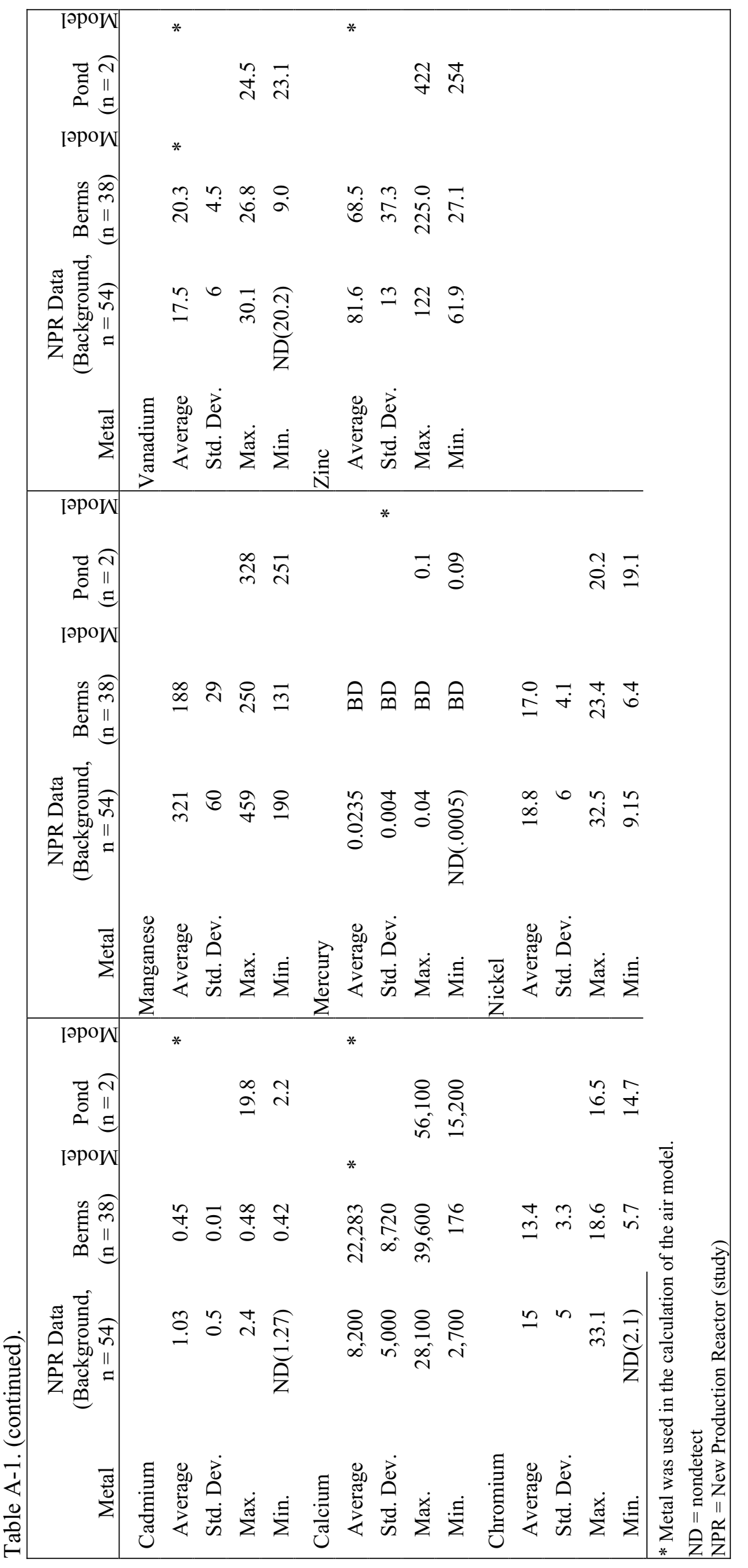


Table A-2. Calculated metal emissions from excavating berm and gun range soils at the STF- 02 site.

\begin{tabular}{lcccc} 
& $\begin{array}{c}\text { Average Soil } \\
\text { Concentration } \\
(\mathrm{mg} / \mathrm{kg})\end{array}$ & $\begin{array}{c}\text { Mass of } \\
\text { Contaminant in } \\
\text { Excavated Soil } \\
(\mathrm{g})\end{array}$ & $\begin{array}{c}\text { Potential } \\
\text { Emission Rate } \\
(\mathrm{lb} / \mathrm{hr})\end{array}$ & $\begin{array}{c}\text { Idaho Emission } \\
\text { Limits } \\
(\mathrm{lb} / \mathrm{hr})\end{array}$ \\
\hline Antimony & 4.8 & $1.06 \mathrm{E}+05$ & $1.99 \mathrm{E}-04$ & $3.30 \mathrm{E}-02$ \\
Arsenic & 6.1 & $1.37 \mathrm{E}+05$ & $2.56 \mathrm{E}-04$ & $1.50 \mathrm{E}-06$ \\
Calcium & 22,283 & $4.97 \mathrm{E}+08$ & $9.29 \mathrm{E}-01$ & $6.67 \mathrm{E}-01$ \\
Copper & 97 & $2.15 \mathrm{E}+06$ & $4.03 \mathrm{E}-03$ & $6.70 \mathrm{E}-02$ \\
Lead & 2,508 & $5.60 \mathrm{E}+07$ & $1.05 \mathrm{E}-01$ & - \\
Selenium & 0.46 & $1.03 \mathrm{E}+04$ & $1.94 \mathrm{E}-05$ & $1.30 \mathrm{E}-02$ \\
Silver & 0.45 & $1.01 \mathrm{E}+04$ & $1.88 \mathrm{E}-05$ & $1.00 \mathrm{E}-03$ \\
Vanadium & 20 & $4.54 \mathrm{E}+05$ & $8.49 \mathrm{E}-04$ & $3.00 \mathrm{E}-03$ \\
\hline
\end{tabular}

Table A-3. Calculated metals emissions from excavating pond soils at the STF-02 site.

\begin{tabular}{lcccc} 
& $\begin{array}{c}\text { Maximum Soil } \\
\text { Concentration } \\
(\mathrm{mg} / \mathrm{kg})\end{array}$ & $\begin{array}{c}\text { Mass of } \\
\text { Contaminant in } \\
\text { Excavated Soil } \\
(\mathrm{g})\end{array}$ & $\begin{array}{c}\text { Potential } \\
\text { Emission Rate } \\
(\mathrm{lb} / \mathrm{hr})\end{array}$ & $\begin{array}{c}\text { Idaho Emission } \\
\text { Limits } \\
(\mathrm{lb} / \mathrm{hr})\end{array}$ \\
\hline Aluminum & 9,590 & $5.83 \mathrm{E}+06$ & $4.01 \mathrm{E}-01$ & $1.33 \mathrm{E}-01$ \\
Arsenic & 7.4 & $4.50 \mathrm{E}+03$ & $3.09 \mathrm{E}-04$ & $1.50 \mathrm{E}-06$ \\
Barium & 226 & $1.37 \mathrm{E}+05$ & $9.45 \mathrm{E}-03$ & $3.30 \mathrm{E}-02$ \\
Cadmium & 19.8 & $1.20 \mathrm{E}+04$ & $8.28 \mathrm{E}-04$ & $3.70 \mathrm{E}-06$ \\
Calcium & 56,100 & $3.41 \mathrm{E}+07$ & $2.35 \mathrm{E}+00$ & $6.67 \mathrm{E}-01$ \\
Copper & 271 & $1.65 \mathrm{E}+05$ & $1.13 \mathrm{E}-02$ & $6.70 \mathrm{E}-02$ \\
Lead & 2,190 & $1.33 \mathrm{E}+06$ & $9.16 \mathrm{E}-02$ & - \\
Magnesium & 8,750 & $5.32 \mathrm{E}+06$ & $3.66 \mathrm{E}-01$ & $6.67 \mathrm{E}-01$ \\
Mercury & 0.1 & $6.08 \mathrm{E}+01$ & $4.18 \mathrm{E}-06$ & $1.00 \mathrm{E}-03$ \\
Selenium & 0.48 & $2.92 \mathrm{E}+02$ & $2.01 \mathrm{E}-05$ & $1.30 \mathrm{E}-02$ \\
Silver & 0.48 & $2.92 \mathrm{E}+02$ & $2.01 \mathrm{E}-05$ & $1.00 \mathrm{E}-03$ \\
Sodium & 259 & $1.57 \mathrm{E}+05$ & $1.08 \mathrm{E}-02$ & $1.33 \mathrm{E}-01$ \\
Thallium & 0.96 & $5.83 \mathrm{E}+02$ & $4.01 \mathrm{E}-05$ & $7.00 \mathrm{E}-03$ \\
Vanadium & 24.5 & $1.49 \mathrm{E}+04$ & $1.02 \mathrm{E}-03$ & $3.00 \mathrm{E}-03$ \\
Zinc & 422 & $2.56 \mathrm{E}+05$ & $1.76 \mathrm{E}-02$ & $6.67 \mathrm{E}-01$ \\
\hline
\end{tabular}




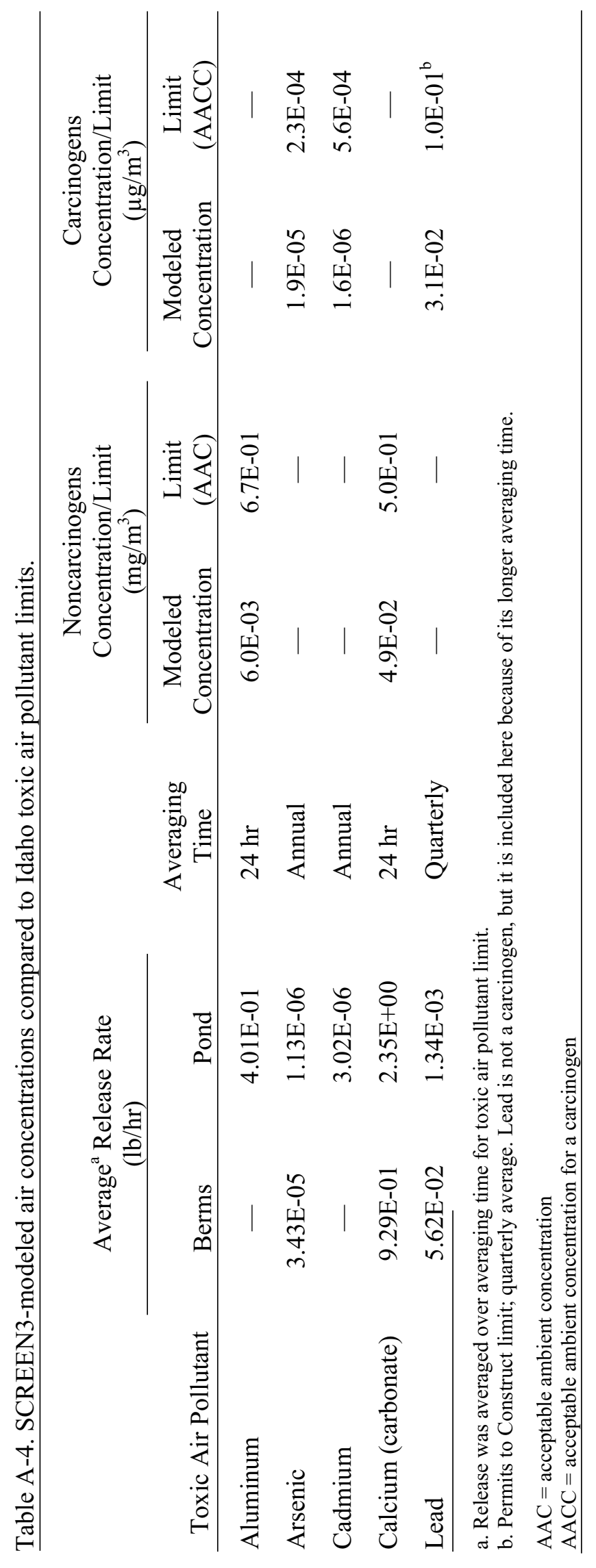


A-12 
Appendix A-1

SCREEN3 Output File 
A-14 


\section{BEE-Line SCREEN3 Version 3.20}

$12 / 15 / 04$

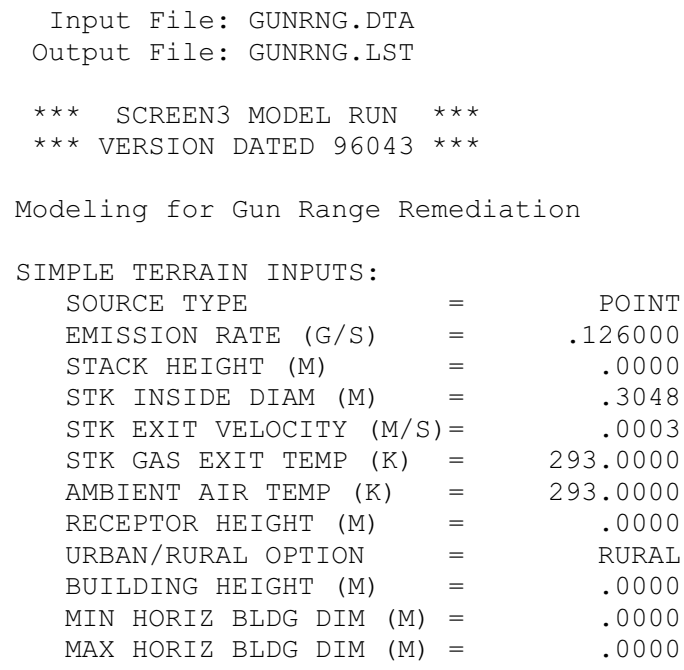


A-16 
Appendix B

Waste Management Plan 
B-2 


\section{Appendix B}

\section{Waste Management Plan \\ B-1. PURPOSE/INTRODUCTION}

The purpose of this Waste Management Plan is to establish requirements for the management and disposal of waste generated during the remediation of lead-contaminated soil at the Security Training Facility (STF) -02 Gun Range at the Idaho National Laboratory (INL). The work activities will be performed under Waste Area Group (WAG) 10, Operable Unit (OU) 10-04 at the INL Site. The scope of this plan covers industrial and hazardous waste generated as a result of OU 10-04 remediation activities conducted at the STF-02 Gun Range at the INL Site. This plan allows for the disposition of waste at approved on-Site treatment and disposal facilities or off-Site treatment and disposal facilities, as deemed necessary. The plan also provides reference to the applicable waste management requirements that are contained in U.S. Department of Energy Idaho Operations Office (DOE-ID) documents. The overall scope of the OU 10-04 Phase III remediation activities is presented in the main body of this report, "Remedial Design/Remedial Action Work Plan for Operable Units 6-05 and 10-04, Phase III."

Activities that could likely generate waste include, but are not limited to, the following:

- $\quad$ Excavating contaminated soil

- $\quad$ Removing the wooden structure located at the remediation site

- $\quad$ Removing creosote-contaminated railroad ties located at the remediation site

- $\quad$ Removing fencing and electrical components at the remediation site

- $\quad$ Performing field screening and sampling

- $\quad$ Performing stabilization of soil and/or microencapsulation of debris, as necessary

- Decontaminating equipment and materials

- $\quad$ Performing packaging, transportation, and disposal activities

- Performing reclamation of the terrain, including backfilling, contouring, and revegetation.

\section{B-2. PROJECT-SPECIFIC WASTE CHARACTERISTICS}

Several distinct waste types could be generated during this project as a result of remediation activities, including the following:

- $\quad$ Lead and copper fragments

- $\quad$ Soil, gravel, and rock

- $\quad$ Sand and wood from the structure located at the site

- Creosote-contaminated railroad ties used for placing targets and in the wooden structure 
- $\quad$ Creosote-contaminated power poles

- $\quad$ Personal protective equipment (PPE)

- $\quad$ Plastic sheeting, sampling debris, etc.

- Hydraulic oil spills

- $\quad$ Liquid decontamination residue

- $\quad$ Solid decontamination residue.

Some of this waste may be clean, but much of it could be contaminated. Subsequent to generation, any or all of the waste may be reclassified. Resource Conservation and Recovery Act (RCRA) -regulated constituents (42 USC $\S 6901$ et seq.) previously encountered in soil samples collected from the site include lead from some areas that exceeds the toxicity characteristic leaching procedure regulatory concentration of $5.0 \mathrm{mg} / \mathrm{L}$. Based on these results, some of the soils will be characteristic for lead, thereby requiring stabilization prior to disposal. Further characterization of the soil for the toxicity characteristic will be performed prior to direct disposal of contaminated soil to determine whether the soil is truly characteristic.

\section{B-3. WASTE IDENTIFICATION}

All waste generated as a result of the remedial activities conducted at the STF-02 Gun Range will be considered Comprehensive Environmental Response, Compensation, and Liability Act (CERCLA) waste (42 USC $\S 9601$ et seq.). Based on a review of work activities and previously collected analytical data, the following potential waste types have been identified:

- $\quad$ CERCLA Waste: Lead-contaminated soils that are not RCRA characteristic are not considered hazardous. Those soils that are not RCRA characteristic but exceed the remediation goal for lead will be disposed of at the Idaho CERCLA Disposal Facility (ICDF) as CERCLA waste.

- Industrial Waste: Solid waste generated by industrial processes, manufacturing, and support processes (40 CFR 243, "Guidelines for the Storage and Collection of Residential, Commercial, and Industrial Solid Waste"). At the INL, industrial waste to be disposed of at the INL Landfill Complex does not include hazardous waste, radioactive waste, or land disposal restricted waste regulated under Subtitle C of RCRA (42 USC $\S 6901$ et seq.).

- Hazardous Waste: Solid waste designated as hazardous by the U.S. Environmental Protection Agency's RCRA regulations (40 CFR 261.3, "Definition of Hazardous Waste").

These waste categories are intended to indicate general waste disposition pathways and do not detract from the overall categorization of the waste as being the end result of the CERCLA process. Waste that may be generated during remediation activities is summarized in Table B3-1. This table describes the waste types, provides the anticipated disposition pathway, and references the waste acceptance criteria or guidance for management. For the ICDF landfill, the waste acceptance criteria concentration guideline for lead is $58,000 \mathrm{mg} / \mathrm{kg}$. The landfill waste acceptance criteria maximum mass for lead is $4.4 \mathrm{E}+7 \mathrm{~kg}$. If the contaminated soil cannot be disposed of at the ICDF Complex, an off-Site treatment and disposal facility will need to be identified. 
Table B3-1. Possible waste generation and disposition.

\begin{tabular}{|c|c|c|c|}
\hline Waste Description & Waste Type & $\begin{array}{l}\text { Disposition } \\
\text { Pathway }^{\mathrm{a}} \\
\end{array}$ & $\begin{array}{l}\text { Appropriate Waste } \\
\text { Acceptance } \\
\text { Criteria/Guidance } \\
\end{array}$ \\
\hline $\begin{array}{l}\text { Administrative waste (paper products } \\
\text { and office waste) }\end{array}$ & Industrial & $\begin{array}{l}\text { INL Landfill } \\
\text { Complex }\end{array}$ & $\begin{array}{l}\text { Waste Acceptance Criteria } \\
\text { (DOE-ID 2005a) }\end{array}$ \\
\hline Contaminated soil (non-characteristic) & CERCLA & ICDF landfill & $\begin{array}{l}\text { ICDF Waste Acceptance } \\
\text { Criteria (DOE-ID 2005b) }\end{array}$ \\
\hline Contaminated soil (characteristic) & Hazardous & Off-Site TSDF & To be determined \\
\hline STF-612 Wooden Building & Industrial & $\begin{array}{l}\text { INL Landfill } \\
\text { Complex }\end{array}$ & $\begin{array}{l}\text { Waste Acceptance Criteria } \\
\text { (DOE-ID 2005a) }\end{array}$ \\
\hline Creosote-treated railroad ties & Hazardous & Off-Site TSDF & To be determined \\
\hline Asphalt pads & Industrial & $\begin{array}{l}\text { INL Landfill } \\
\text { Complex }\end{array}$ & $\begin{array}{l}\text { Waste Acceptance Criteria } \\
\text { (DOE-ID 2005a) }\end{array}$ \\
\hline $\begin{array}{l}\text { Lead debris (fragments and unfired } \\
\text { rounds) }\end{array}$ & Industrial & Recycle & MCP-454 \\
\hline $\begin{array}{l}\text { Copper debris (fragments and unfired } \\
\text { rounds) }\end{array}$ & Industrial & Recycle & MCP-454 \\
\hline Uncontaminated monitoring waste & Industrial & $\begin{array}{l}\text { INL Landfill } \\
\text { Complex }\end{array}$ & $\begin{array}{l}\text { Waste Acceptance Criteria } \\
\text { (DOE-ID 2005a) }\end{array}$ \\
\hline Contaminated monitoring waste & Hazardous & ICDF landfill & $\begin{array}{l}\text { ICDF Waste Acceptance } \\
\text { Criteria (DOE-ID 2005b) }\end{array}$ \\
\hline $\begin{array}{l}\text { Uncontaminated PPE (e.g., gloves, } \\
\text { boots, shoe covers, and coveralls) }\end{array}$ & Industrial & $\begin{array}{l}\text { INL Landfill } \\
\text { Complex }\end{array}$ & $\begin{array}{l}\text { Waste Acceptance Criteria } \\
\text { (DOE-ID 2005a) }\end{array}$ \\
\hline $\begin{array}{l}\text { Contaminated PPE (e.g., gloves, boots, } \\
\text { shoe covers, and coveralls) }\end{array}$ & Hazardous & ICDF landfill & $\begin{array}{l}\text { ICDF Waste Acceptance } \\
\text { Criteria (DOE-ID-2005b) }\end{array}$ \\
\hline $\begin{array}{l}\text { Uncontaminated sampling waste } \\
\text { (e.g., wipes and spoons) }\end{array}$ & Industrial & $\begin{array}{l}\text { INL Landfill } \\
\text { Complex }\end{array}$ & $\begin{array}{l}\text { Waste Acceptance Criteria } \\
\text { (DOE-ID 2005a) }\end{array}$ \\
\hline $\begin{array}{l}\text { Contaminated sampling waste } \\
\text { (e.g., wipes and spoons) }\end{array}$ & Hazardous & ICDF landfill & $\begin{array}{l}\text { ICDF Waste Acceptance } \\
\text { Criteria (DOE-ID 2005b) }\end{array}$ \\
\hline $\begin{array}{l}\text { Liquid and solid decontamination } \\
\text { residues }\end{array}$ & Hazardous & ICDF Complex & $\begin{array}{l}\text { ICDF Waste Acceptance } \\
\text { Criteria (DOE-ID 2005b) }\end{array}$ \\
\hline $\begin{array}{l}\text { Petroleum-contaminated media } \\
\text { (i.e., soil, plastic sheeting, and PPE } \\
\text { from hydraulic fluid spills) }\end{array}$ & Industrial & CFA landfill & $\begin{array}{l}\text { Waste Acceptance Criteria } \\
\text { (DOE-ID 2005a) }\end{array}$ \\
\hline $\begin{array}{l}\text { Contaminated equipment that cannot be } \\
\text { decontaminated }\end{array}$ & Hazardous & ICDF landfill & $\begin{array}{l}\text { ICDF Waste Acceptance } \\
\text { Criteria (DOE-ID 2005b) }\end{array}$ \\
\hline $\begin{array}{l}\text { Maintenance-related waste (e.g., from } \\
\text { vehicles, equipment, and facilities) }\end{array}$ & Industrial & $\begin{array}{l}\text { INL Landfill } \\
\text { Complex }\end{array}$ & $\begin{array}{l}\text { Waste Acceptance Criteria } \\
\text { (DOE-ID 2005a) }\end{array}$ \\
\hline
\end{tabular}


Table B3-1. (continued).

\begin{tabular}{|c|c|c|c|}
\hline Waste Description & Waste Type & $\begin{array}{l}\text { Disposition } \\
\text { Pathway }^{\mathrm{a}}\end{array}$ & $\begin{array}{l}\text { Appropriate Waste } \\
\text { Acceptance } \\
\text { Criteria/Guidance } \\
\end{array}$ \\
\hline $\begin{array}{l}\text { Spent or unusable (e.g., expired) } \\
\text { chemicals, reagents, and field test kits }\end{array}$ & $\begin{array}{l}\text { Industrial or } \\
\text { hazardous }\end{array}$ & ICDF Complex & $\begin{array}{l}\text { ICDF Waste Acceptance } \\
\text { Criteria (DOE-ID 2005b) }\end{array}$ \\
\hline $\begin{array}{l}\text { Miscellaneous waste (e.g., tools, debris, } \\
\text { equipment, metal/plastic pipe, and } \\
\text { plastic sheeting) }\end{array}$ & $\begin{array}{l}\text { Industrial or } \\
\text { hazardous }\end{array}$ & $\begin{array}{l}\text { INL Landfill } \\
\text { Complex }\end{array}$ & $\begin{array}{l}\text { Waste Acceptance Criteria } \\
\text { (DOE-ID 2005a) }\end{array}$ \\
\hline \multicolumn{4}{|c|}{$\begin{array}{l}\text { a. The ultimate disposition path is contingent upon meeting the appropriate facility's waste acceptance criteria. If the waste } \\
\text { does not meet the waste acceptance criteria, and an alternative on-Site treatment and disposal location is not available, then } \\
\text { off-Site waste disposal options will be pursued. }\end{array}$} \\
\hline $\begin{array}{l}\text { CERCLA = Comprehensive Environmental Resp } \\
\text { CFA = Central Facilities Area } \\
\text { DOE-ID = U.S. Department of Energy Idaho Ope } \\
\text { ICDF = Idaho CERCLA Disposal Facility } \\
\text { INL = Idaho National Laboratory } \\
\text { MCP = Management Control Procedure } \\
\text { PPE = personal protective equipment } \\
\text { STF = Security Training Facility } \\
\text { TSDF = Treatment, Storage, and Disposal Facility }\end{array}$ & $\begin{array}{l}\text { sse, Compensation } \\
\text { titions Office }\end{array}$ & and Liability Act & \\
\hline
\end{tabular}




\section{B-4. WASTE DESIGNATION AND MANAGEMENT}

All generated waste will be characterized as required by RCRA regulations (40 CFR 262.11, "Hazardous Waste Determination"). Hazardous waste determinations will be prepared for each waste stream in accordance with the requirements delineated in Management Control Procedure (MCP)-63, "Waste Generator Services-Industrial Waste Management."

Waste generated from the STF-02 Gun Range will be designated and characterized using process knowledge, historical analytical data, and/or analytical data generated during the course of remediation activities. The Waste Generator Services organization will maintain completed hazardous waste determinations for all waste streams as part of the project file. Potential waste streams that might be generated during remediation activities include the following:

- Industrial solid waste to be disposed of at the INL Landfill Complex

- $\quad$ CERCLA waste (i.e., noncharacteristic soil) to be disposed of at the ICDF

- Hazardous solid waste (i.e., RCRA-characteristic soil) to be stabilized and disposed of at an offSite treatment, storage, and disposal facility

- $\quad$ Hazardous solid waste (i.e., RCRA-regulated debris) to be macroencapsulated and disposed of at an off-Site treatment, storage, and disposal facility

- $\quad$ Lead and copper fragments to be recycled.

Once the hazardous waste determinations are completed, the appropriate information will be entered into the INL Integrated Waste Tracking System. All waste must meet the applicable waste acceptance criteria for the intended treatment/disposal facility prior to disposal.

\section{B-4.1 CFA Landfill Waste Disposal}

Historically, the CFA Landfills I, II, and III were evaluated under CERCLA as Operable Unit (OU) 4-12. The risk assessment for OU 4-12 indicated that the landfills did not pose an unacceptable risk to human health or the environment; however, due to uncertainty associated with the landfill contents, it was determined that a remedial action was warranted for the site. Given this determination, a remedy was implemented to minimize these landfills as a source of potential groundwater contamination and reduce potential risks associated with exposure to contaminated waste. The major components of the selected remedy included the following:

- $\quad$ Placement of a native soil cover to a minimum depth of $2 \mathrm{ft}$, compacted and graded to minimize erosion and infiltration of surface water

- Implementation of administrative controls on future land use

- $\quad$ Conducting groundwater, surface water, and/or vadose zone monitoring

- $\quad$ Periodically inspecting the cover

- $\quad$ Maintaining institutional controls, including signs, postings, and land-use restrictions.

Consistent with the 2002 Record of Decision Experimental Breeder Reactor-I/Boiling Water Reactor Experiment Area and Miscellaneous Sites, Operable Units 6-05 and 10-04 (DOE-ID 2002), 
approximately $10 \mathrm{~m}^{3}\left(13 \mathrm{yd}^{3}\right)$ of debris comprised of asphalt pads, a wooden building, and miscellaneous waste generated during the remediation of the STF- 02 Gun Range will be disposed of in the active portion of the CFA landfill. Based on historical analytical results, the debris is below the human health and ecological risk levels established in the Record of Decision (DOE-ID 2002). The landfill is appropriate for this waste stream, because no contaminants are present that pose an unacceptable threat to the underlying aquifer.

The INL Landfill Complex is considered a nonmunicipal solid waste landfill and is operated and maintained in accordance with the substantive requirements of 40 CFR 258, "Criteria for Municipal Solid Waste Landfills." Existing and future landfill cells will be closed in accordance with the applicable regulations.

\section{B-4.2 Industrial Waste}

Solid waste and debris that are not contaminated (not an RCRA-characteristic, listed, or mixed waste) and have been radiologically released are considered industrial waste. This waste may be disposed of at the INL Landfill Complex, subject to meeting that facility's waste acceptance criteria. Industrial waste generated during remediation activities will be transported to the INL Landfill Complex, which is located at CFA, for disposal. The waste must meet the waste acceptance criteria, which are described in the Idaho National Engineering and Environmental Laboratory Waste Acceptance Criteria (DOE-ID 2005a), prior to disposal at the landfill. The Idaho National Engineering and Environmental Laboratory Waste Acceptance Criteria (DOE-ID 2005a) document requires some industrial waste to be segregated and managed as conditional industrial waste. Conditional industrial waste includes oil or fuel filters, petroleum-contaminated material from spills, asbestos-containing materials, or uncontaminated PPE.

\section{B-4.3 Hazardous Waste}

Contaminated (hazardous) solid waste (nonaqueous) that meets the ICDF's waste acceptance criteria will be treated and disposed of at the ICDF. Contaminated aqueous waste that meets the ICDF's waste acceptance criteria will be disposed of at the ICDF evaporation pond. Aqueous and nonaqueous waste not meeting the ICDF's disposal requirements will be containerized, treated, and/or stored (as necessary) until the appropriate treatment/disposal criteria are met. If management and disposal at INL facilities is not possible, then waste may be sent to an approved off-Site facility for treatment and disposal, subject to meeting the acceptable waste acceptance criteria and off-Site criteria.

\section{B-4.4 Recycling}

Lead will be recycled in accordance with the requirements delineated in MCP-454, "INEEL Recycling." Lead bullets with copper jackets must be previously discharged and segregated from other materials and managed as RCRA scrap metal. The container in which the copper-jacketed lead bullets are placed will be labeled "Lead/copper jacketed bullets." Materials held for recycling will be sent off-Site under an approved subcontract administered by Waste Generator Services.

\section{B-4.5 Contaminated Soils Planned for Treatment, Storage, or Disposal}

Soils that are excavated that require treatment, storage, or disposal will be expeditiously placed in trucks or other transportation containers for transport. When transport is not expeditiously available after excavation (within 5 working days), contaminated soils will be placed in staging piles or appropriate 
containers (e.g., bags, covered roll-on/roll-offs, metal waste containers, or wooden boxes) to be managed until transport is available. These staging piles or containers will be inspected no less frequently than weekly to ensure the piles or containers are managed in compliance with the standards and requirements contained within this section of the WMP pertaining to soil staging.

Staging piles will be managed in accordance with applicable or relevant and appropriate requirements of 40 CFR 264.554. The requirements below provide the Agencies the opportunity to review, comment, and concur with the management of soils under this approach. The Agencies concurrence with this WMP is the CERCLA equivalent of the director's designation of the standards and design criteria that would be required to operate staging piles if this project was regulated under RCRA requirements.

The management of contaminated soils in staging piles requires compliance with the following requirements:

- Contaminated soils shall be stockpiled in staging piles or containers located near or adjacent to the area of excavation.

- Only solid, non-flowing remediation waste that would meet the definition of remediation waste in 40 CFR 260.10 shall be included in the staging piles or containers.

- $\quad$ Treatment of waste in these staging piles or containers is not allowed.

- $\quad$ Staging piles or containers will be used expressly for the purpose of facilitating an effective remedial action.

- $\quad$ Staging piles shall be covered or have stabilization agents applied whenever active remedial activities are not underway (e.g., when active movement of soils either into or out of the pile are not proceeding during normal operational periods) in order to reduce wind-blown or precipitationenhanced releases of contamination. In case the soils are staged in bags, these shall be closed to isolate the soils from the outside area. However, these bags need not be covered. Run-on/run-off controls will be maintained to preclude pooling of water and possible impact on the surrounding area from the contaminated stockpile.

- Access to the staging piles will be restricted by the use of signs and fences, as appropriate.

- Ignitable and/or reactive soil cannot be stored in staging piles or bags unless the waste has been treated and is no longer ignitable or reactive.

- The staging piles or containers must be established and maintained to ensure separation of incompatible soil and other waste.

- $\quad$ Upon completion of remediation activities the staging piles will be removed. If the staging piles were placed on the ground, an additional 6 in. of soil will be removed to constitute removal of the staging piles and any soils that were contaminated as a result. These wastes will be disposed at an approved disposal facility in order to complete remediation activities. The area that was beneath the staging piles is subject to the same confirmation sampling as specified in the Field Sampling Plan for the Operable Units 6-05 and 10-04 Remedial Action, Phase III (DOE-ID 2006), Section 4.2.4 to ensure that the contaminated soils have been effectively removed.

- Removal of the staging piles will constitute closure. If the staging pile wastes were placed on the ground, removal of the staging piles includes the removal of the additional 6 in. of soil and 
confirmation sampling to verify that the remaining soil meets the remediation goals. Closure of the staging piles will be documented in the prefinal inspection and the remedial action report.

- $\quad$ Contaminated equipment associated with the staging piles will be removed, disposed, or decontaminated for reuse.

- $\quad$ Staging piles are to be removed by the end of the field season immediately following the field season in which the staging piles was created unless specific approval for an extension is obtained from the Agencies.

\section{B-4.6 Waste Storage}

While waste is being actively generated by the STF-02 Gun Range contaminated soil remedial operations, the waste will be temporarily managed and stored within the designated work area in containers appropriate for the type of waste being generated (e.g., hazardous liquids require secondary containment). Unless being actively filled, the containers shall remain closed at all times. The volume of waste stored at the site shall be kept to a minimum. All waste located at the task site shall be removed for disposal prior to demobilization. No waste shall be stored at the site over the winter, should the remediation timeframe extend beyond the annual shutdown of the ICDF landfill, which is tentatively scheduled for November 15th each year.

Whenever possible, waste containers will be removed from the active work area directly to the ICDF or the CFA Landfill Complex, as appropriate. If temporary storage is required, a staging area will be established within the area of concern. Waste stored there will be labeled and roped off in compliance with applicable company and regulatory requirements. If the waste is stored at the treatment, storage, and disposal facility, the CERCLA-regulated waste (42 USC $\S 9601$ et seq.) will be managed in accordance with that facility's waste management plan.

If direct transfer of small waste containers (i.e., drums or boxes) to the treatment, storage, and disposal facility is not feasible, containers may be stored temporarily in an established CERCLA storage area located in the CFA-637 building. This could be necessary pending container profile approvals and facility acceptance. If temporary storage is required because of space limitations or safety concerns, the CERCLA storage area may be expanded or a new CERCLA storage area may be established to accommodate the waste.

The CERCLA storage area is located at CFA and managed in accordance with the substantive requirements of RCRA, as applicable, for temporary storage of waste (40 CFR 264, Subpart I, "Use and Management of Containers"). For example, if CERCLA waste with RCRA waste codes is stored in a CERCLA storage area, then the following items are located, tested, and maintained unless hazards associated with the waste streams would not require the item:

1. Current copy of the registration posted at the CERCLA storage area

2. Communications, spill control, and safety equipment, as identified in the Health and Safety Plan for the Operable Units 6-05 and 10-04 Remedial Action, Phase III (ICP 2005)

3. "NO SMOKING" signs at or near a CERCLA storage area that stores ignitable or reactive waste.

Additional requirements include appropriate management of containers at the CERCLA storage area that includes the following: 
1. Maintain the containers in good condition

2. Do not store waste that is incompatible with containers (or container liners) or place the waste in a container that previously held an incompatible waste or material

3. Keep all containers closed except when adding, removing, sampling, or measuring waste

4. Do not mix incompatible waste

5. Maintain sufficient aisle space (minimum of $71 \mathrm{~cm} \mathrm{[28} \mathrm{in.])} \mathrm{to} \mathrm{allow} \mathrm{the} \mathrm{unobstructed} \mathrm{movement}$ of emergency equipment and personnel

6. Do not open, handle, or store any container in a manner that will cause it to leak

7. Perform and document weekly CERCLA storage area inspections by qualified personnel.

Personnel trained in the management of a CERCLA waste storage area will inspect the temporary storage area weekly. The purpose of the inspections is to evaluate container integrity, verify correct container labeling, and correct any noted deficiency or issue. Inspections are documented on the CERCLA storage area checklist that is maintained within each CERCLA storage area. "Temporary Storage of CERCLA-Generated Waste at the INEEL Site" (MCP-3475) will be used as guidance on storage and inspection of each CERCLA storage area. The CERCLA storage area will be signed and access controlled to ensure that no unauthorized access occurs by untrained personnel.

\section{B-5. WASTE PACKAGING, LABELING, AND TRANSPORTATION}

Containers used to store CERCLA-regulated waste must be in good condition, compatible with the waste being stored, and properly labeled. The Idaho National Engineering and Environmental Laboratory Waste Acceptance Criteria document (DOE-ID 2005a) details the criteria for waste packaging. Containers for the collection of this waste will be clearly labeled to identify the waste type and will be maintained inside the work area until removal for subsequent waste management activities. The Idaho National Engineering and Environmental Laboratory Waste Acceptance Criteria document (DOE-ID 2005a) also provides guidance to ensure that the containers selected for storage and the method of packaging are compatible with final disposition plans and applicable U.S. Department of Transportation requirements. Following this guidance will alleviate the need for repackaging the waste before shipment to a treatment or disposal facility.

The types of containers that may be used for storage and transport of waste streams generated during remedial activities include the following:

- $\quad$ Plastic bags

- 19-L (5-gal) open-head drums and/or 208-L (55-gal) open-head drums

- $\quad 1.2 \times 1.2 \times 2.4-\mathrm{m}(4 \times 4 \times 8$-ft) metal waste boxes (or equivalent)

- $\quad$ Roll-off containers lined with burrito bags

- $\quad$ End-load dump trucks.

Roll-off containers lined with burrito bags will be used for soil and other solid waste intended for direct disposal in the ICDF landfill. End-load dump trucks may be used for waste requiring storage in the 
ICDF bulk storage area pending treatment required to meet the land disposal restrictions before disposal in the ICDF landfill. Bags, drums, and waste boxes may be used for other solid waste types pending direct disposal or treatment, as required (e.g., construction debris, PPE, or sampling waste). All waste will be containerized in compliance with the facility's waste acceptance criteria, based on specific storage, treatment, and disposal requirements at the receiving facility. The packaging is intended to protect against contaminant migration and environmental degradation. Low-volume contaminated waste associated with activities may be bagged, taped, and labeled. To reduce the number of separate bags, similar waste may be combined and accounted for in one bag and/or container in consultation with Waste Generator Services personnel. During site activities, the workers will transport this bagged material in a protective manner (i.e., containment of the material is maintained). The waste may be either directly transported to the disposal facility or accumulated in a container (or containers) at the CERCLA storage area already established at CFA and will be managed pending approval and transport to its final disposition path.

Containers will be marked and labeled appropriately to match the designation established for each waste stream. Uncontaminated waste will be placed in containers marked as "Cold Waste." Containers will be marked with labels identifying them as "CERCLA Waste" if contaminated or as "Cold Waste" if uncontaminated.

Standard green and yellow CERCLA waste labels shall include appropriate information on the waste packaging, as follows:

- $\quad$ The accumulation start data

- $\quad$ Name of generating facility (e.g., OU 10-04)

- Waste description

- $\quad$ Phone number of generator contact

- $\quad$ Listed or characteristic code(s), if applicable.

Other labels and markings may include, as applicable:

- Waste package gross weight

- U.S. Department of Transportation marking/labels

- Waste stream or material identification number as assigned by Waste Generator Services

- $\quad$ Other labels and markings as required by 49 CFR 172, Subparts D and E.

A unique bar code serial number from the INL Integrated Waste Tracking System also will be placed on the container to facilitate management. The boxes and containers shall, at a minimum, be labeled on one side with the "CERCLA Waste" label and the Integrated Waste Tracking System sticker (visible side labeled) prior to transportation.

Any of the above information that is not known when the waste is labeled may be added when the information becomes available. Waste Generator Services will provide the unique bar codes and serial numbers. A new bar code will be affixed to each container when waste is first placed in the container. In addition, waste labels must be visible, legibly printed or stenciled, and placed so that a full set of labels and markings are readily visible.

Packaging and labeling for transportation shall meet U.S. Department of Transportation requirements, as appropriate. Packaging exceptions to these requirements, which are documented and 
provide an equivalent degree of safety during transportation, may be used for on-Site waste shipments. Containers will be labeled and marked appropriately to match the designation established for each waste stream.

\section{B-6. WASTE MINIMIZATION AND SEGREGATION}

Waste minimization techniques will be incorporated primarily through design, planning, and efficient operations. Specific waste minimization practices to be implemented during the project will include, but not be limited to, the following:

- Excluding materials that could become hazardous waste in the decontamination process (if any)

- Controlling transfer of materials and equipment between clean and contaminated zones

- $\quad$ Designing containment such that spread of contamination is minimized

- Deploying appropriate decontamination methods.

Reuse and recycling opportunities also will be evaluated for waste (such as batteries, scrap metal, and equipment or materials that are no longer needed). Uncontaminated equipment that is determined to be excess will be evaluated for reuse by other INL projects or a government surplus sale.

\section{B-7. REFERENCES}

40 CFR 243, 2002, "Guidelines for the Storage and Collection of Residential, Commercial, and Institutional Solid Waste," Code of Federal Regulations, Office of the Federal Register, February 2002.

40 CFR 258, 2005, "Criteria for Municipal Solid Waste Landfills," Code of Federal Regulations, Office of the Federal Register, August 2005

40 CFR 261.3, 2005, "Definition of Hazardous Waste," Code of Federal Regulations, Office of the Federal Register, September 2005.

40 CFR 262.11, 2005, "Hazardous Waste Determination," Code of Federal Regulations, Office of the Federal Register, September 2005.

40 CFR 264, Subpart I, 2005, "Use and Management of Containers," Code of Federal Regulations, Office of the Federal Register, September 2005.

40 CFR 300, 2005, "National Oil and Hazardous Substances Pollution Contingency Plan," Code of Federal Regulations, Office of the Federal Register, September 2005.

49 CFR 172, Subpart D, 2005, "Marking," Code of Federal Regulations, Office of the Federal Register, August 2005.

49 CFR 172, Subpart E, 2005, "Labeling," Code of Federal Regulations, Office of the Federal Register, August 2005.

58 FR 49200, 1993, "Amendment to the National Oil and Hazardous Substances Pollution Contingency Plan; Procedures for Planning and Implementing Off-Site Response Action," Federal Register, U.S. Environmental Protection Agency, September 22, 1993. 
42 USC § 6901 et seq., 1976, "Resource Conservation and Recovery Act (Solid Waste Disposal Act)," United States Code, October 21, 1976.

42 USC $§ 9601$ et seq., 1980, “Comprehensive Environmental Response, Compensation and Liability Act of 1980 (CERCLA/Superfund),” United States Code, December 11, 1980.

DOE-ID, 2002, Record of Decision Experimental Breeder Reactor-I/Boiling Water Reactor Experiment Area and Miscellaneous Sites, Operable Units 6-05 and 10-04, DOE/ID-10980, Rev. 0, U.S. Department of Energy Idaho Operations Office; U.S. Environmental Protection Agency, Region 10; Idaho Department of Environmental Quality, November 2002.

DOE-ID, 2005a, Idaho National Engineering and Environmental Laboratory Waste Acceptance Criteria, DOE/ID-10381, Rev. 21, U.S. Department of Energy Idaho Operations Office, January 2005.

DOE-ID, 2005b, ICDF Complex Waste Acceptance Criteria, DOE/ID-10881, Rev. 2, U.S. Department of Energy Idaho Operations Office, July 2005.

DOE-ID, 2006, Field Sampling Plan for the Operable Units 6-05 and 10-04 Remedial Action, Phase III, DOE/NE-ID-11212, Rev. 1, Idaho Cleanup Project, August 2006.

ICP, 2005, Health and Safety Plan for the Operable Units 6-05 and 10-04 Remedial Action, Phase III, ICP/EXT-04-00697, Rev. 0, Idaho National Laboratory, Idaho Cleanup Project, July 2005.

ICP-MCP-3475, 2004, “Temporary Storage of CERCLA-Generated Waste at the INEEL Site,” Rev. 1, Manual 8-Environmental Protection and Compliance, Idaho Completion Project, August 2004.

MCP-63, 2005, "Waste Generator Services-Industrial Waste Management," Rev. 9, Manual 17-Waste Management, Idaho National Engineering and Environmental Laboratory, January 2005.

MCP-454, 2005, “INEEL Recycling,” Rev. 10, Manual 17-Waste Management, Idaho National Laboratory, April 2005. 


\section{Appendix C}

\section{Operations and Maintenance Plan for Operable Units 6-05 and 10-04, Phase III}




$$
\text { C-2 }
$$




\section{Operations and Maintenance Plan for Operable Units 6-05 and 10-04, Phase III}

\section{C-1. INTRODUCTION}

Remediation for Operable Units (OU) 6-05 and 10-04, hereinafter referred to as OU 10-04, at the Idaho National Laboratory (INL) is divided into four phases:

- $\quad$ Phase I consists of developing and implementing institutional controls at OU 10-04 sites and developing and implementing an INL Sitewide institutional controls plan and long-term ecological monitoring plan

- $\quad$ Phase II will remediate sites contaminated with trinitrotoluene and Royal Demolition Explosive

- $\quad$ Phase III will remediate lead contamination at the Security Training Facility (STF)-02 gun range

- $\quad$ Phase IV will address hazards from unexploded ordnance.

Separate remedial design/remedial action work plans and operations and maintenance (O\&M) plans will be submitted for each remediation phase. The scope and schedule for implementing these remediation phases are presented in the Operable Units 6-05 and 10-04, Experimental Breeder Reactor-I/Boiling Water Reactor Experiment Area and Miscellaneous Sites, Remedial Design/Remedial Action Scope of Work (DOE-ID 2003).

The site-specific O\&M Plan describes the long-term activities and procedures that will be performed to satisfy requirements for the Record of Decision Experimental Breeder Reactor-I/Boiling Water Reactor Experiment Area and Miscellaneous Sites, Operable Units 6-05 and 10-04 (DOE-ID 2002) and the Operable Units 6-05 and 10-04, Experimental Breeder Reactor-I/Boiling Water Reactor Experiment Area and Miscellaneous Sites, Remedial Design/Remedial Action Scope of Work (DOE-ID 2003). These activities and procedures will comprise the Phase III remediation effort for the lead-contaminated STF-02 Gun Range.

This plan outlines the O\&M activities that will be conducted and documented in the O\&M report at the completion of the remedial action activities at the OU 10-04 sites. After remediation actions at the OU 10-04 sites are complete, this O\&M plan may be modified based on the results of the final confirmation sampling. The institutional control requirements are based on provisions in the INEEL Sitewide Institutional Controls Plan (DOE-ID 2004a), which was included as Attachment 1 to the Remedial Design/Remedial Action Work Plan for Operable Units 6-05 and 10-04, Phase I (DOE-ID 2004b).

As remediation in Phases II-IV is completed for the OU 10-04 sites, the O\&M requirements will be modified based on the residual levels of contamination. For the Phase III activities surrounding the STF-02 Gun Range, it is anticipated that all of the lead contamination exceeding the $400-\mathrm{mg} / \mathrm{kg}$ final remediation goal will be removed and institutional controls will not be required following the completion of the remedial action.

The basic elements of this O\&M Plan are organized as follows:

- Section C2 - This section provides background information on the nature of contamination at the STF-02 Gun Range and a description of the current controls 
- Section C3 - This section describes the requirements for institutional controls, environmental monitoring, site-specific O\&M, and 5-year reviews

- $\quad$ Section C4 - This section describes O\&M implementation, including organization, responsibilities, and requirements for conducting monitoring, maintenance, and inspections

- $\quad$ Section C5-This section summarizes the reporting requirements for institutional controls, environmental monitoring, site-specific O\&M, and 5-year reviews

- $\quad$ Section C6-This section lists the references cited in this plan.

In accordance with the Federal Facility Agreement and Consent Order for the Idaho National Engineering Laboratory (DOE-ID 1991), the U.S. Department of Energy Idaho Operations Office (DOE-ID) will submit an O\&M report to the U.S. Environmental Protection Agency (EPA) and the Idaho Department of Environmental Quality (DEQ) (hereinafter referred to as the Agencies) once the O\&M activities have been completed. In accordance with the Phase I Remedial Design/Remedial Action Work Plan (DOE-ID 2004b), a draft O\&M report will be submitted to the Agencies by May 31, 2008.

\section{C-2. BACKGROUND}

Between the 1950s and 1980s, research activities at the INL left behind contaminants that pose risks to human health and the environment. A comprehensive remedial investigation/feasibility study was performed to determine the nature and extent of contamination at the Waste Area Group (WAG) 5, OU 6-05 Experimental Breeder Reactor-I/Boiling Water Reactor Experiment and WAG 10, OU 10-04 miscellaneous sites. The investigation is detailed in the Comprehensive Remedial Investigation/Feasibility Study for Waste Area Groups 6 and 10 Operable Unit 10-04 (DOE-ID 2001).

Waste Area Group 10 and OU 10-04 include miscellaneous INL sites outside the other WAGs at the INL (WAGs 1-9). In addition, OU 10-08 is included in WAG 10 and was added to evaluate INL-wide groundwater concerns and new sites that are passed to WAG 10 by other WAGs. The OU 10-08 comprehensive remedial investigation/feasibility study and record of decision will address these sites and the groundwater and will be prepared following the completion of the final record of decision for either OU 3-14 or OU 7-13/14, whichever is later. Therefore, OU 10-04 will not address INL-wide groundwater issues and potential new sites. Figure 1-3 in the main body of this document depicts the STF-02 Gun Range. Section 3.2 provides a summary of the contamination at the gun range. A more detailed description of the site is provided in the Record of Decision (DOE-ID 2002).

\section{C-3. DESCRIPTION OF OPERATIONS AND MAINTENANCE}

\section{C-3.1 Institutional Controls}

The DOE-ID will implement and maintain institutional controls at Comprehensive Environmental Response, Compensation, and Liability Act (CERCLA) (42 USC § 9601 et seq.) sites at the INL where contamination precludes unrestricted use. The DOE-ID ensures that institutional controls will be in effect for the next 100 years or more, unless a 5-year review concludes that unrestricted land use is allowable and institutional controls are no longer required. Institutional controls will not be required if (1) all contaminated media are removed, (2) contamination concentrations are comparable to local background values, or (3) residual concentrations allow unrestricted use. 
All institutional control requirements for OU 10-04 sites-including implementation, maintenance, inspection, monitoring, enforcement, and reporting - are addressed in the INEEL Sitewide Institutional Controls Plan (DOE-ID 2004a), which is included as Attachment 1 of the Phase I Remedial Design/Remedial Action Work Plan (DOE-ID 2004b). The INEEL Sitewide Institutional Controls Plan is the principal document governing establishment, implementation, enforcement, and monitoring of institutional controls at all INL sites requiring institutional controls under CERCLA. The INEEL Sitewide Institutional Controls Plan was developed in accordance with the Record of Decision requirements (DOE-ID 2002). Institutional controls for all OU 10-04 sites will include a CERCLA sign; some sites also require physical access restrictions.

Permission from the WAG 10 remediation project manager must be obtained prior to any disturbances to the STF-02 Gun Range. Signs posted at the logical points of entrance identify the potential hazards, provide a point of contact, and stipulate that the Warning Communications Center must be contacted before disturbing the site. Other access controls include training and escort requirements and restrictions on land use. An excavation permit is required for any work involving land disturbance (such as drilling or excavation), which must be approved by a health and safety officer who is familiar with the site before fieldwork can commence.

\section{C-3.2 Environmental Monitoring}

Ecological monitoring is the only type of environmental monitoring to be conducted under OU 10-04 and will occur as part of the Phase I activities. In accordance with the provisions of the Record of Decision (DOE-ID 2002), a long-term ecological monitoring plan has been implemented to ensure protection of the INL's ecosystem. Ecological monitoring will be performed in accordance with the requirements delineated in the Long-Term Ecological Monitoring Plan for the Idaho National Engineering and Environmental Laboratory (INEEL 2004). The purpose of long-term ecological monitoring is to eliminate uncertainty in the INL-wide ecological risk assessment, allow coordination with ongoing environmental monitoring efforts, allow coordination with other agency activities, and address stakeholder concerns.

Ecological monitoring may be discontinued at the INL Site after a 5-year review if the Agencies decide that monitoring is no longer required. The Agencies also may change the frequency of environmental monitoring in a 5-year review. As stated in the Record of Decision (DOE-ID 2002), OU 10-08 is responsible for groundwater monitoring; therefore, groundwater monitoring is not an activity for OU 10-04. Any post remediation monitoring required for the STF-02 Gun Range will be determined once the remedial actions for Phases II-IV have been completed.

\section{C-3.3 Operation and Maintenance}

The STF-02 Gun Range requires remedial action as identified in the Record of Decision (DOE-ID 2002), which will be performed in this Phase III of the OU 10-04 remediation. Until remediation of the site is performed, institutional controls to protect human health will be established and maintained. The institutional control requirements for the gun range are addressed in the INEEL Sitewide Institutional Controls Plan (DOE-ID 2004a), which is included as Attachment 1 of the Phase I Remedial Design/Remedial Action Work Plan (DOE-ID 2004b). The institutional controls will remain in place until it is determined either through submittal of and concurrence with a remedial action report or during a 5 -year review that they are no longer necessary. 


\section{C-3.4 Five-Year Reviews}

In accordance with the "National Oil and Hazardous Substances Pollution Contingency Plan" (40 CFR 300) for sites where contamination is left in place above risk-based levels for unrestricted use, a review of the selected remedy will be conducted every 5 years until it is determined by the Agencies to be unnecessary. During the 5-year review, the remedy is evaluated to determine if it remains protective of human health and the environment. The review also includes an evaluation of new data that could change the monitoring or controls in place for the sites. It is the intent that a consolidated 5-year review will be performed for the four phases of the OU 10-04 remedial action and will be included in the INL Sitewide 5 -year review. The first INL Sitewide 5-year review will be completed in 2005 with subsequent reviews occurring every 5 years henceforth. Once the OU 10-08 record of decision has been completed, aspects of OU 10-08 will be incorporated into the INL Sitewide 5-year review with reviews to be performed every 5 years until it is determined by the Agencies to be unnecessary.

\section{C-4. OPERATIONS AND MAINTENANCE IMPLEMENTATION}

This section summarizes the activities needed to implement the Phase III O\&M requirements for OU 10-04. These activities include performing inspections, outlining the organizational practices that will drive the O\&M activities, and specifying the individuals responsible for performing the activities. As described in Section D-3, there are no planned operations or scheduled maintenance activities. However, it may be necessary to perform unscheduled maintenance and repairs if additional contamination is found.

\section{C-4.1 Organization and Responsibilities}

\section{C-4.1.1 U.S. Department of Energy Idaho Operations Office Project Manager}

The DOE-ID WAG 6/10 remediation project manager is responsible for (a) ensuring that the O\&M activities are performed in accordance with this approved plan and (b) overseeing the activities of the INL contractor at WAG 6, OU 6-05 and WAG 10, OU 10-04.

\section{C-4.1.2 Idaho National Laboratory Management and Operations Contractor}

As the point of contact for O\&M activities, the INL contractor WAG 6/10 remediation project manager will be responsible for maintaining document control of inspection reports (including placement in the project records file), administrating subcontracts for performing required activities, and reporting activities to DOE-ID.

\section{C-4.2 Conducting Monitoring, Maintenance, and Inspections}

The WAG 6/10 contractor will provide qualified personnel to perform the O\&M activities for remedial actions under the OU 10-04 Record of Decision (DOE-ID 2002). Personnel will be trained on the requirements of the approved plan before performing O\&M activities. The INL contractor WAG 6/10 project manager is responsible for inspection implementation and reporting.

\section{C-4.2.1 Institutional Controls}

Institutional controls will be implemented and maintained at the STF-02 Gun Range until remediation is complete and it is determined either through the submittal of and Agency concurrence with a remedial action report or during a 5-year review that institutional controls are no longer required. Requirements and frequency for institutional control inspection and maintenance are addressed in the 
INEEL Sitewide Institutional Controls Plan (DOE-ID 2004a), which is included as Attachment 1 to the Phase I Remedial Design/Remedial Action Work Plan (DOE-ID 2004b). The inspections will address institutional control requirements for the site (such as identification and warning signs, visible access restrictions, administrative controls, and land-use restrictions).

\section{C-4.2.2 Environmental Monitoring}

Long-term ecological monitoring will be conducted as prescribed in the Record of Decision (DOE-ID 2002). Details of the ecological monitoring are described in the Long-Term Ecological Monitoring Plan (INEEL 2004), which is included as Attachment 2 to the Phase I Remedial Design/Remedial Action Work Plan (DOE-ID 2004b).

\section{C-4.2.3 Operations and Maintenance}

No routine maintenance is planned for the STF-02 Gun Range. The only planned routine activities will involve inspection and maintenance of CERCLA signs and any existing physical access restrictions (e.g., fencing). Signs of unauthorized intrusion also will be monitored during the site inspections. These routine activities will be performed under the requirements delineated in the INEEL Sitewide Operations and Maintenance Plan for CERCLA Response Actions (DOE-ID 2004c).

\section{C-5. REPORTING REQUIREMENTS}

Reporting requirements related to institutional controls, environmental monitoring, O\&M, and 5 -year reviews are summarized in the following subsections. The purpose of these reporting activities is to ensure that all activities are documented adequately and that related data and information are provided to the Agencies for review and decision making. Although the following subsections indicate separate reporting requirements and separate reports, the reporting requirements may be met by combining the information into a single annual report. The frequency of all the reporting identified in the following subsections will be reviewed by the Agencies during the first 5-year review and may be adjusted to an alternative frequency during that or any subsequent reviews. All reports will be submitted electronically to the INL Information Repository for records storage.

\section{C-5.1 Institutional Control Reporting}

Reporting requirements for institutional controls are specified in the INEEL Sitewide Institutional Controls Plan (DOE-ID 2004a), which is included as Attachment 1 of the Phase I Remedial Design/Remedial Action Work Plan (DOE-ID 2004b). An institutional control monitoring report will be prepared and submitted to the Agencies for information on an annual basis throughout the duration of the site's O\&M activities.

\section{C-5.2 Environmental Monitoring Reporting}

The only environmental monitoring to be conducted by OU 10-04 is the long-term ecological monitoring. Data and results from the ecological monitoring will be compiled and presented in an annual monitoring report. This annual report will be prepared and submitted to the Agencies for information.

\section{C-5.3 Operations and Maintenance Reporting}

Data and results from annual inspections (e.g., information regarding site intrusions, warning signs, and physical access restrictions) will be compiled and presented in an annual report, which will be 
submitted to the Agencies for information. The report will contain documentation of scheduled inspections, follow-up and contingency inspections, and maintenance activities. It will include the following as a minimum:

- General OU description and operational history

- A summary of the inspection

- A summary of maintenance activities to date

- An estimate of maintenance activities required in the next year

- A copy of the appropriate inspection report forms.

\section{C-5.4 Five-Year Review Reporting}

Data and results from the annual reports for institutional controls, environmental monitoring, and O\&M will be summarized and addressed in a 5-year review report. The 5-year review report will be prepared in accordance with the requirements delineated in the Idaho National Engineering and Environmental Laboratory Sitewide Five-Year Review Plan for CERCLA Response Actions (DOE-ID 2004d). Additional content requirements for the report will be developed and included in future revisions to that plan.

\section{C-6. REFERENCES}

40 CFR 300, 2005, "National Oil and Hazardous Substances Pollution Contingency Plan," Code of Federal Regulations, Office of the Federal Register, September 2005.

42 USC $\S 9601$ et seq., 1980, "Comprehensive Environmental Response, Compensation and Liability Act of 1980 (CERCLA/Superfund)," United States Code, December 11, 1980.

DOE-ID, 1991, Federal Facility Agreement and Consent Order for the Idaho National Engineering Laboratory, Administrative Docket No. 1088-06-29-120, U.S. Department of Energy Idaho Operations Office; U.S. Environmental Protection Agency, Region 10; Idaho Department of Health and Welfare, December 4, 1991.

DOE-ID, 2001, Comprehensive Remedial Investigation/Feasibility Study for Waste Area Groups 6 and 10 Operable Unit 10-04, DOE/ID-10807, Rev. 0, U.S. Department of Energy Idaho Operations Office, August 2001.

DOE-ID, 2002, Record of Decision Experimental Breeder Reactor-I/Boiling Water Reactor Experiment Area and Miscellaneous Sites, Operable Units 6-05 and 10-04, DOE/ID-10980, Rev. 0, U.S. Department of Energy Idaho Operations Office, November 2002.

DOE-ID, 2003, Operable Units 6-05 and 10-04, Experimental Breeder Reactor-I/Boiling Water Reactor Experiment Area and Miscellaneous Sites, Remedial Design/Remedial Action Scope of Work, DOE/ID-11035, Rev. 0, U.S. Department of Energy Idaho Operations Office, February 2003.

DOE-ID, 2004a, INEEL Sitewide Institutional Controls Plan, DOE/ID-11042, Rev. 1, U.S. Department of Energy Idaho Operations Office, June 2004. 
DOE-ID, 2004b, Remedial Design/Remedial Action Work Plan for Operable Units 6-05 and 10-04, Phase I, DOE/ID-11101, Rev. 0, U.S. Department of Energy Idaho Operations Office, February 2004.

DOE-ID, 2004c, INEEL Sitewide Operations and Maintenance Plan for CERCLA Response Actions, DOE/NE-ID-11159, Rev. 0, U.S. Department of Energy Idaho Operations Office, September 2004.

DOE-ID, 2004d, Idaho National Engineering and Environmental Laboratory Sitewide Five-Year Review Plan for CERCLA Response Actions, DOE/NE-ID-11125, Rev. 2, U.S. Department of Energy Idaho Operations Office, September 2004.

INEEL, 2004, Long-Term Ecological Monitoring Plan for the Idaho National Engineering and Environmental Laboratory, INEEL/EXT-02-01191, Rev. 1, Idaho Completion Project, January 2004. 
C-10 


\section{Attachment 1}

\section{Construction Specification}


Att 1-2 


\title{
Construction Specification
}

\author{
Project No. 23368
}

\section{Remediation of the STF-02 Gun Range}


412.15

2/1/2006

Rev. 05
ICP CONTROLLED DOCUMENT

APPROVAL SHEET

1. Document identifier: SPC-646

2. Project File No. (optional): 23368

3. Reyision No: ?

4. Document Title: Remediation of the STF-02 Gun Range

5. Comments:

\begin{tabular}{|c|c|c|c|}
\hline \multicolumn{4}{|c|}{ SIGNATURES } \\
\hline $\begin{array}{c}6 . \\
\text { Type or Printed Name }\end{array}$ & Signature & & $\begin{array}{c}8 . \\
\text { Organization/ }\end{array}$ \\
\hline Signature & Code & Date & Discipline \\
\hline
\end{tabular}

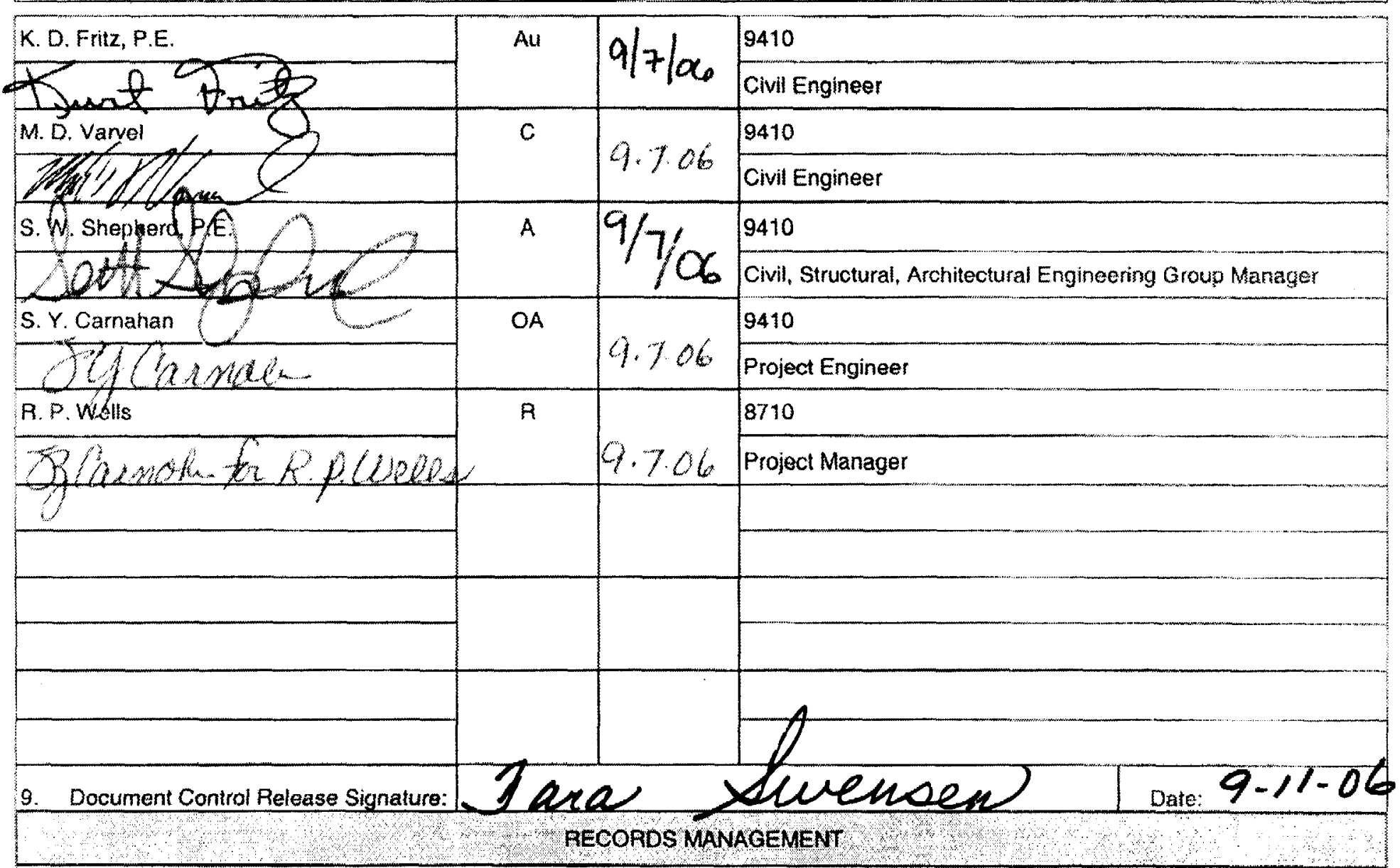

10. Is this a Construction Specification? Yes $\square$ No $\square$ 11. NCA Related? Yes $\square$ No $\triangle$

12. Does document contain sensitive, unclassified information? $\square$ Yes $\square$ No If Yes, what category:

13. Can document be externally distributed? Yes $\square$ No $\square$

14. Area Index Code: Area___ Type_ SSCID

15. Uniform File Code: 0250

17. For QA Pecords Classification Only: ttem or activity to which the QA Records apply:

18. Periodic Review Frequency: N/A $\triangle, 5$ years $\square$, or Other 


\section{REMEDIATION OF THE STF-02 GUN RANGE}

The following Sections of this Specification were prepared under the direction of the Registered Professional Engineer as indicated by the seal and signature provided on this page. The Professional Engineer is registered in the State of Idaho to practice Civil Engineering.

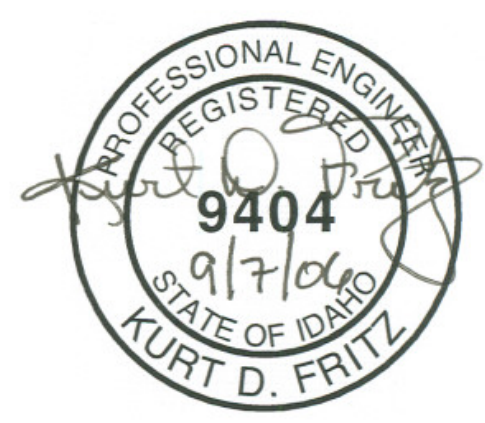

Division 1 -- General Requirements

01005 -- Summary of Work

01051 -- Construction Surveying and Staking

01300 -- Submittals

$\underline{\text { Division } 2 \text {-- Site Work }}$

02062 -- Demolition and Repairs

02200 -- Earthwork

02486 -- Revegetation 


\title{
SPECIFICATIONS \\ FOR \\ REMEDIATION OF THE STF-02 GUN RANGE \\ REVISION 2
}

\author{
Prepared for: \\ U. S. DEPARTMENT OF ENERGY \\ IDAHO OPERATIONS OFFICE
}

Idaho Falls, Idaho

Project File No. 23368

September 2006

\section{CH2M-WG IDAHO, LLC (CWI)}

Idaho Falls, Idaho 83415 
TABLE OF CONTENTS

REMEDIATION OF THE STF-02 GUN RANGE

REVISION 2

Number

of pages in

TITLE

Section

DIVISION 1--GENERAL REQUIREMENTS

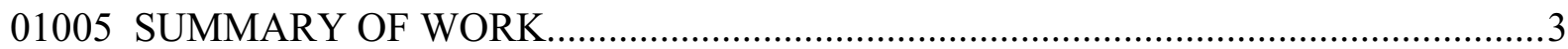

01051 CONSTRUCTION SURVEYING AND STAKING .............................................

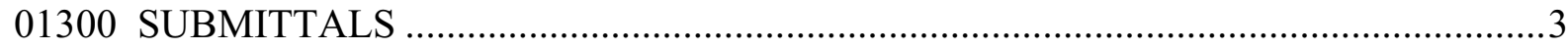

DIVISION 2 SITE WORK

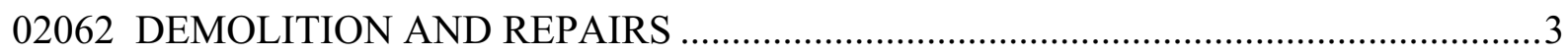

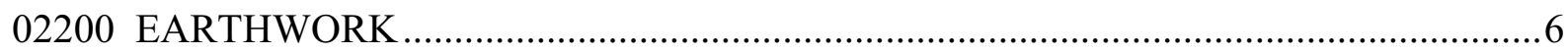

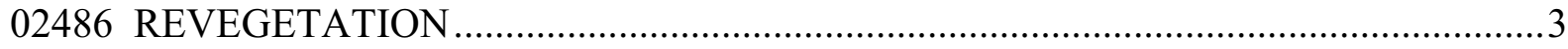




$\begin{array}{llrl}\text { Project Title: } & \text { Remediation of the STF-02 Gun Range } \\ \text { Document Type: } & \text { Construction Specification } & \text { Project Number: } & 23368 \\ \text { SPC } & 646 & \text { Revision: } & 2\end{array}$

\section{SECTION 01005--SUMMARY OF WORK}

\section{PART 1--GENERAL}

\section{SUMMARY:}

Remediation of the STF-02 Gun Range site is required in accordance with the DOE/NE-ID11202 Remedial Design/Remedial Action Work Plan for Operable Units 6-05 and 10-04, Phase III. Remediation will require excavation, physical separation, and disposition of leadcontaminated soils found at the STF-02 Gun Range.

The Subcontractor shall furnish plant, labor, material, equipment, and supplies (except

Activities for the remediation for the STF-02 Gun Range site include:

\section{$\underline{\text { STF-02 Gun Range Site }}$}

- Demolish and remove the estimated 2900-sf of asphalt pads

- Excavate the lead contaminated soil at the locations and to the depths as outlined on the construction drawings. Stockpile the estimated 500cy of removed soil at the designated collection area at the STF-02 Gun Range

- $\quad$ Demolish and remove the wood Shoot House structure. Size, package and transport, to an on-site disposal location, the estimated 96 creosote-contaminated railroad ties that make up the Shoot House interior walls and foundation. Collect the sand that is contained within the two interior Shoot House walls. Stockpile the estimated 3.5-cy of sand at the designated collection area at the STF-02 Gun Range

- $\quad$ Remove, size, package, and transport, to an on-site disposal location, the estimated 10 creosote-contaminated railroad ties that comprise the shooting targets

- Demolish and remove the perimeter fencing

- Isolate, demolish, and remove the above ground electrical circuits and components. Remove the buried electrical circuits, if encountered during general demolition or soil removal

- $\quad$ Following removal of soils by the Subcontractor, the Contractor will perform sampling to verify that remediation goals have been met. Subcontractor shall remove and stockpile any additional soils as identified by the Contractor 


\section{Project Title: $\quad$ Remediation of the STF-02 Gun Range \\ Document Type: Construction Specification $\quad$ Project Number: 23368 \\ SPC \\ 646 \\ Revision: 2}

- $\quad$ Use berm materials to backfill the EOCR Leach Pond and grade the remediation area to emulate the surrounding topography and

- Topographical surveys of the STF-02 Gun Range site

- $\quad$ Revegetate the disturbed area.

$\underline{\text { Stockpiled Lead Contaminated Soil: }}$

- $\quad$ Perform screening of the collected soils and sand

- $\quad$ Segregate and package the screened material for disposition by the Contractor

\section{REFERENCES:}

The following documents, including others referenced therein, form part of this Section to the extent designated herein.

\section{CODE OF FEDERAL REGULATIONS (CFR)}

29 CFR 1910

29 CFR 1926

IDAHO NATIONAL LABORATORY (INL)

DOE/NE-ID-11202 Remedial Design/Remedial Action Work Plan for Operable Units 6-05 and 10-04, Phase III

PROC-185

SRM

OSHA Occupational Safety and Health Standards

OSHA Health and Safety Standards for Construction

General Provisions for Fixed Price Construction Subcontracts

Subcontractor Requirements Manual

Unless otherwise specified, references in these specifications, codes, standards or manuals that are part of these specifications, but not included herein, shall be the latest edition, including any amendments and revisions, in effect as of the date of this Specification.

\section{SUBMITTALS:}

Submittals include, but are not limited to the following:

Hazardous Chemicals and Substances: Subcontractor shall submit a list of hazardous chemicals and substances in accordance with General Provisions for approval. Chemicals and substances not previously approved for use will require the submittal of MSDS for approval. 


\section{Project Title: $\quad$ Remediation of the STF-02 Gun Range \\ Document Type: Construction Specification Project Number: 23368 SPC 646 \\ Revision: 2}

1 QUALITY ASSURANCE:

3 Quality Assurance Program requirements shall exist to assure that work performed is in

4 conformance with the requirements established by the drawings and this specification. QA

5 Program criteria applicable to this scope of work is addressed in the Special Conditions,

6 Subcontractor Requirements Manual, General Provisions, and these specifications.

8 SAFETY, HEALTH AND ENVIRONMENT:

10 In general work shall be in compliance with the applicable sections of 29 CFR 1910, 29 CFR

$11 \quad 1926$ and the Subcontractor Requirements Manual.

12

13 END OF SECTION 01005 


\section{Project Title: $\quad$ Remediation of the STF-02 Gun Range \\ Document Type: Construction Specification $\quad$ Project Number: 23368 \\ SPC \\ 646 \\ Revision: 2}

\section{SECTION 01051--CONSTRUCTION SURVEYING AND STAKING}

\section{PART 1--GENERAL}

\section{SUMMARY:}

Section Includes: Work includes, but is not limited to:

The Subcontractor shall furnish all materials, labor, tools and equipment to perform all surveying necessary to lay out and control the construction work. The Subcontractor shall perform surveying to establish excavation boundaries as set forth in these specifications, the construction drawings, and the DOE/NE-ID-11202

Remedial Design/Remedial Action Work Plan for the Operable Units 6-05 and 10-04, Phase III. See Section 02200 for definition of excavation terms.

\section{SUBMITTALS:}

Submittals include but are not limited to the following:

Certification: Submit certification that the land surveyor is a registered professional in the State of Idaho.

Topographical Surveys: Electronic data shall be reduced and plotted by the Subcontractor in standard ASCII and AutoCAD 14 format. Electronic data shall be submitted on electronic media such as Compact Disks (CD) or Digital Video Disks (DVD). Legible notes, drawings, and electronic data files (including point number, northing, easting, elevation, and point description) shall be submitted to the Contractor for approval. Each topographical survey shall include a topographical map of the area with a contour interval of 1-foot. At a minimum the survey shall include all breaks in grade, swales, and other natural features with sufficient detail to accurately model the surface. In areas where the terrain is relatively flat, a grid of no greater than 50-ft in all directions shall be used. All surveys shall be conducted using the established project datum. Required surveys shall consist of:

1) Topographical survey of the original topography prior to disturbance (including EOCR Leach Pond)

2) Topographical survey of the berm areas and Leach Pond, after contaminated soil removal, to determine quantities of material for grading

3) Topographical survey of the final graded/disturbed surface prior to revegetation. The survey shall include a boundary line showing the limits of revegetation.

The topographic surveys will be used to calculate compacted in-place graded quantities as well as revegetation areas. 


\section{Project Title: $\quad$ Remediation of the STF-02 Gun Range \\ Document Type: Construction Specification Project Number: 23368 SPC \\ Revision: 2}

\section{QUALITY CONTROL:}

Qualifications: Construction surveying and staking shall be accomplished under the direction of a registered professional land surveyor.

\section{PART 2--PRODUCTS}

Stakes: Identification stakes and hubs shall be of sufficient length, width and depth to provide a solid set in the ground and to provide space for marking above ground when applicable. The top 2 -in. of all stakes shall be painted or marked with plastic flagging.

\section{PART 3--EXECUTION}

\section{SURVEY REQUIREMENT:}

Control: Use existing controls as required. The coordinates of the existing controls will be provided by the Contractor. Prior to commencement of construction work, the Subcontractor shall establish survey controls inside the work area.

Project Datum: Horizontal coordinates are based on NAD27 Idaho East Zone State Plane. All surveying for the project construction shall be based on this datum. Vertical datum shall be NGVD29.

Monuments of Property Boundaries or Surveys of Other Agencies: If property boundary or survey monuments, or survey markers of other agencies, are found within or adjacent to the construction limits, the Subcontractor shall immediately notify the Contractor's Representative. These monuments shall not be disturbed.

\section{METHOD OF MEASUREMENT:}

Surveying: Surveying will not be measured.

\section{BASIS OF PAYMENT:}

Surveying: Payment for surveying shall be included in the contract unit price for excavation.

\section{FIELD QUALITY CONTROL:}

Surveillance will be performed by the Contractor's Representative to verify compliance of the work to the drawings and specifications.

END OF SECTION 01051 


$\begin{array}{llrl}\text { Project Title: } & \text { Remediation of the STF-02 Gun Range } \\ \text { Document Type: } & \text { Construction Specification } & \text { Project Number: } & 23368 \\ \text { SPC } & 646 & \text { Revision: } & 2\end{array}$

\section{$\underline{\text { SECTION 01300--SUBMITTALS }}$}

\section{PART 1--GENERAL}

\section{SUMMARY:}

This section specifies the administrative, technical and quality requirements for vendor data submittals. Vendor data requirements are specified in individual specification sections or on the drawings, and tabularized on a Vendor Data Schedule. In the event of conflicting requirements, the submittal requirements prescribed in the individual specification section shall take top priority, the drawings second and the vendor data schedule last.

The Subcontractor shall submit data, drawings, and other submittals specified. If the Contractor determines the Subcontractor's submittal to be incomplete or unacceptable, the Subcontractor shall make a complete and acceptable submittal to the Contractor by the second submission of a submittal item.

The Subcontractor shall be responsible for providing submittals in accordance with the Subcontract General Provisions Document, providing submittals with adequate time for review and resubmittal, and advising the Contractor of any submittal that may be delayed and which might, if further delayed, extend completion of the project.

Section Includes, but is not limited to:

The preparation, transmittal and delivery of documents by the Subcontractor to the Contractor as required in the "Submittals" subdivision of the specification sections and as provided on the Vendor Data Schedule.

Related Sections: General Provisions, Subcontractor Requirements Manual, Special Conditions, Drawings, Vendor Data Schedule, and other sections of these specifications apply to this section.

\section{REFERENCES:}

The following documents, including others referenced therein, form part of this Section to the extent designated herein:

\section{AMERICAN NATIONAL STANDARDS INSTITUTE (ANSI)}

\section{SUBMITTALS:}

General Procedures: Vendor data, whether prepared by the Subcontractor or Subcontractor's subtier or supplier, shall be submitted as instruments of the Subcontractor. Therefore, prior to submittal, the Subcontractor shall ascertain that material and equipment covered by the 


\section{Project Title: $\quad$ Remediation of the STF-02 Gun Range \\ Document Type: Construction Specification $\quad$ Project Number: 23368 SPC 646 \\ Revision: 2}

submittal and the contents of the submittal itself, meet all the requirements of the subcontract specifications, drawings, or other contract documents.

Each submittal shall contain identification for each separable and separate piece of material or equipment, and literature with respect to the information provided in the specification and on the Vendor Data Schedule. Submittals shall be numbered consecutively for each different submittal.

Vendor Data Schedule: Vendor data required by the specification sections or the drawings to support design, construction, and operation of the project is identified on a Vendor Data Schedule. The Vendor Data Schedule provides a tabular listing by item number, drawing or specification reference, and description of the item or service. The type of submittal is identified by a "Vendor Data Code", and the time required to submit the item is identified by a "When to Submit" code. An "Approval" code specifies whether the submittal is for Mandatory Approval or for Information Only. One copy of routine paper or electronic file submittals are required; additional copies may be required by the Vendor Data Schedule. Electronic file submittals are preferred. Submittals that cannot be scanned or provided electronically, such as large shop drawings, will require 6 copies for Mandatory Approval and 4 copies for Information Only. Material or color samples will require 2 sets for Mandatory Approval and 1 set for Information Only.

Or Equal Material or Equipment Submittals: All "or equal" materials, equipment or systems shall be identified and submitted for approval as required by the Subcontractor Requirements Manual.

An "or equal" submittal shall contain as a minimum all operating and physical parameters necessary to show that the material or equipment is equivalent to the specified material or equipment. All parameters shall be specifically identified by the submitter in the proposal. Exceptions or differences between the specified item and the "or equal" item shall also be identified.

If an "or equal" material, equipment or system is approved, the Subcontractor shall be responsible for backup material necessary to include the material, equipment or system in the technical documents.

Vendor Data Transmittal and Disposition Form 431.13: All vendor data shall be submitted to the Contractor using the Vendor Data Transmittal and Disposition Form. The form provides the Subcontractor a method to submit vendor data and provides the Contractor a means of dispositioning the submittal. The Subcontractor shall list the Vendor Data Schedule item number, a Vendor Data Transmittal tracking number (if applicable), the drawing or specification number reference, a Tag Number (if applicable), the submittal status (e.g., Mandatory Approval, Information Only, Re-submittal, or Or-equal), the Revision Level, and the item description. The description should be complete enough that a person unfamiliar with the project can determine what the submittal includes. 


\section{Project Title: $\quad$ Remediation of the STF-02 Gun Range \\ Document Type: Construction Specification $\quad$ Project Number: 23368 SPC 646 \\ Revision: 2}

1 Disposition by the Contractor: The Contractor's comments and required action by the 2 Subcontractor will be indicated by a disposition code on the submittal. The disposition codes

3 will be classed as follows:

(A) "Work May Proceed." Submittals so noted will generally be classed as data that appears to be satisfactory without corrections.

(B) "Work May Proceed with Comments Incorporated. Revise Affected Sections and Resubmit Entire Submittal." This category will cover data that, with the correction of comments noted or marked on the submittal, appear to be satisfactory and require no further review by the Contractor prior to construction.

(C) "Work May NOT Proceed. Revise and Resubmit." Submittals so dispositioned will require a corrected resubmittal for one of the following reasons:

1) Submittal requires corrections, per comments, prior to final review

2) Submittal data incomplete and requires more detailed information prior to final review

3) Submittal data does not meet Subcontract document requirements.

(D) "Received for Information Only." Submittals so dispositioned will generally be classified as Information Only for as-specified material and equipment.

Mandatory Approval coded vendor data will be reviewed by the Contractor and receive an A, $\mathrm{B}$, or $\mathrm{C}$ disposition. The Contractor may provide internal review of Information Only submittals. In the event that comments are generated on an Information Only submittal, the submittal may be dispositioned B or C and returned to the Subcontractor for appropriate action. Information Only submittals without comments will receive a D disposition.

All submittals will be returned to the Subcontractor. Acknowledgment of receipt of dispositioned vendor data by the Subcontractor will not be required.

The Contractor will return dispositioned submittals with reasonable promptness. The Subcontractor shall note that a prompt review is dependent on timely and complete submittals in strict accordance with these instructions.

END OF SECTION 01300 


\section{Project Title: $\quad$ Remediation of the STF-02 Gun Range \\ Document Type: Construction Specification Project Number: 23368 \\ SPC \\ 646 \\ Revision: 2}

\section{$\underline{\text { SECTION 02062--DEMOLITION AND REPAIRS }}$}

PART 1--GENERAL

\section{SUMMARY:}

Section Includes: Work includes, but is not limited to:

- Demolition of the STF-02 Shoot House structure in its entirety

- Demolition of the railroad tie shooting targets

- Demolition of the approximate 2900-sf of asphalt pads

- Demolition of the perimeter fencing

- Isolation of the electrical circuits and demolition and sizing of the power poles, line, and boxes

- $\quad$ Removal and disposal of the burn barrel and test stand from the EOCR Leach Pond.

\section{SUBMITTALS:}

No submittals required.

\section{PROJECT/SITE CONDITIONS:}

Condition of Structures or Facilities: Conditions existing at the time of inspection for bidding purposes will be maintained insofar as practicable. Actual conditions may vary slightly due to operations which may occur prior to start of demolition work.

Protection: Ensure safe passage of persons in the vicinity of the demolition area. Conduct operations to prevent injury to adjacent buildings, structures, other facilities and persons. Provide and erect any necessary temporary enclosures, barricades, walkways, shoring, bracing, etc., to ensure that safe conditions will exist.

Burning: The use of burning at the project site for the disposal of refuse and debris will not be permitted.

Use of Explosives: Use of explosives will not be permitted.

\section{PART 2--PRODUCTS}

\section{MATERIALS:}

Disposition of Removed Equipment and Materials: The Government will retain title to all equipment and materials removed from the work. Materials designated as scrap shall be promptly disposed of as directed by the Special Conditions. Surplus material shall be managed as directed in the Special Conditions. 


\section{Project Title: $\quad$ Remediation of the STF-02 Gun Range \\ Document Type: Construction Specification $\quad$ Project Number: 23368 SPC 646 \\ Revision: 2}

\section{PART 3--EXECUTION}

\section{GENERAL:}

All demolition and repair work shall be done in a neat and orderly manner without any damage to existing facilities not directly involved under this Subcontract. The Subcontractor shall be responsible for all damage to existing buildings or facilities caused by his operations under this Subcontract.

Dust Control: The amount of dust resulting from demolition shall be controlled to prevent the spread of dust to occupied portions of the construction site and the surrounding area. Use of water will not be permitted when it will result in, or create, hazardous or objectionable conditions such as ice, flooding and pollution.

\section{EXISTING STRUCTURES:}

General: The existing Shoot House structure shall be removed in its entirety as indicated on the drawings.

- $\quad$ Size, package, and transport the estimated 96 creosote-contaminated railroad ties that make up the Shoot House interior walls and foundation

- $\quad$ Collect the sand that is contained within the two interior Shoot House walls

- $\quad$ Stockpile the estimated 3.5-cy of lead contaminated sand at the designated collection area

- Demolish and dispose of the wood framing structure, sheathing, and roofing.

\section{CLEAN UP:}

Debris and rubbish shall be removed from the demolition areas. Debris shall be removed and transported in a manner that prevents spillage on streets or adjacent areas. Hauling and disposal shall comply with the Special Conditions.

\section{METHOD OF MEASUREMENT:}

Dust Control: Dust control will not be measured for separate payment.

Asphalt Removal: Asphalt removal shall be measured by the square yard of removed materials.

Shoot House: The shoot house demolition shall be measured by the complete job.

Creosote Railroad Ties: The removal of the estimated 96 railroad ties comprising the shoot house foundation and inner walls, along with the 10 target railroad ties shall be measured by the complete job. 


\section{Project Title: $\quad$ Remediation of the STF-02 Gun Range \\ Document Type: Construction Specification $\quad$ Project Number: 23368 \\ SPC \\ 646 \\ Revision: 2}

1 Perimeter Fencing: The perimeter fencing removal shall be measured by the complete job.

2

3

4

5

Electrical Circuits and Components: The electrical circuits and component isolation and removal shall be measured by the complete job.

\section{BASIS OF PAYMENT:}

Dust Control: No separate payment will be made for dust control. It shall be included in the unit price for excavation.

Asphalt Removal: Asphalt removal will be paid for at the contract unit price per square yard of removal asphalt materials. The cost shall include demolition, loading, and hauling to an on-site disposal facility as designated by the Contractor.

Shoot House: The shoot house demolition and removal will be paid for at the contract unit price for the complete job. The cost shall include demolition, loading, and hauling to an onsite disposal facility as designated by the Contractor.

Creosote Railroad Ties: The railroad tie removal will be paid for at the contract unit price for the complete job. The cost shall include demolition, sizing, packaging, loading, and hauling to an on-site disposal facility as designated by the Contractor.

Perimeter Fencing: The perimeter fencing removal will be paid for at the contract unit price for the complete job. The cost shall include demolition, loading, and hauling to an on-site disposal facility as designated by the Contractor.

Electrical Circuits and Components: The electrical circuits and component removal will be paid for at the contract unit price for the complete job. The cost shall include isolation, removal, sizing, loading, and hauling to an on-site disposal facility as designated by the Contractor.

\section{FIELD QUALITY CONTROL:}

Surveillance will be performed by Contractor's Representative to verify compliance of the work to the drawings and specifications.

END OF SECTION 02062 


\section{Project Title: $\quad$ Remediation of the STF-02 Gun Range \\ Document Type: Construction Specification Project Number: 23368 \\ SPC \\ 646 \\ Revision: 2}

\section{SECTION 02200--EARTHWORK}

PART 1--GENERAL

\section{SUMMARY:}

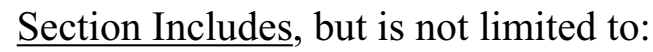

- $\quad$ Excavating all lead contaminated materials as directed by the Contractor

- $\quad$ Stockpiling of the lead contaminated materials near the screening/sieving operations area, if necessary

- $\quad$ Perform screening/sieving of the lead contaminated materials and sand

- $\quad$ Segregating and loading the lead contaminated materials into Contractor supplied containers

- Maintaining dust control

- $\quad$ Loading/Packaging of contaminated soils and lead into Contractor supplied containers for disposal by the Contractor.

- $\quad$ Backfilling of EOCR Leach Pond with clean berm soils

- $\quad$ Grading of the remaining soil berms to match surrounding topography

- $\quad$ Finish grading and grading for revegetation.

\section{REFERENCES:}

The following documents, including others referenced therein, form part of this Section to the extent designated herein.

\section{CODE OF FEDERAL REGULATIONS}

29 CFR 1926

OSHA Safety and Health Regulations for Construction, Subpart P

\section{SUBMITTALS:}

Emissions and Dust Control Plan: This plan shall include, but not be limited to, expected quantity of emissions, sources of emissions, proposed emissions control. If an air pathway analysis indicates monitoring is required, backup calculations, and regulatory information substantiating decisions proposed by the Contractor shall be provided in addition to types and locations of monitoring devices.

See Section 01300, Submittals and the Vendor Data Schedule for additional submittal requirements.

\section{PART 2--PRODUCTS}

\section{MATERIALS AND EQUIPMENT:}




\section{Project Title: $\quad$ Remediation of the STF-02 Gun Range \\ Document Type: Construction Specification $\quad$ Project Number: 23368 SPC 646 \\ Revision: 2}

Topsoil: Clean topsoil free from any toxic minerals, noxious weeds or other objectionable material. Top soil can be obtained from the Rye Grass Flats borrow source (Contact Brenda Pace 526-0916 - Borrow Source Coordinator).

Equipment: All equipment and tools used by the Subcontractor to perform the work shall be subject to inspection by the Contractor before the work is started and shall be maintained in satisfactory working conditions at all times. The Subcontractor's equipment shall have the capability to perform the indicated work specified herein.

Due to the potential for lead contamination, all equipment brought to the site slated for work in the contamination zone shall be identified to the Contractor prior to delivery and shall be clean and free of grease and oil spots where applicable, tires will be in a like-new condition, free of slits, and cracks. The Contractor reserves the right to reject equipment not meeting these standards.

The Subcontractor shall ensure that all equipment used for clearing vegetation or earthwork is fitted with appropriate safety devices that comply with all applicable Federal laws and the Health and Safety Plan (HASP) for the Operable Units 6-05 and 10-04 Remedial Action III (ICP/EXT-04-00697) and adequately protect the operator and minimize exposure of workers and others to potentially contaminated material.

\section{PART 3--EXECUTION}

The Subcontractor shall be responsible for determining the method of excavation to be used for each of the areas identified on the drawings. The excavation method shall make every possible effort to remove the contaminated soil while controlling the depth of excavation and minimizing over excavation. Hand excavation may be required around site features such as fences, power poles, trees, etc. and where localized contamination does not require the use of mechanized excavation equipment.

The Subcontractor shall locate and mark existing monuments, monitoring wells, protection posts, and markers before construction operations commence and protect such items during construction. The Subcontractor shall restore or replace damaged items to original condition as required by the Contractor.

The Subcontractor shall clearly mark and post all laydown areas.

\section{DUST CONTROL:}

The Subcontractor shall minimize the creation and emission of dust per IDAPA Standards 58.01.01.650 and 58.01.01.651 during all work activities performed under this contract. This shall be accomplished by the use of water trucks and visual observation. Water based dust control additives may be used with the approval of the Contractor. The Subcontractor shall control the amount of water used so as not to create flowing water. Source of water for dust suppression is specified in the Special Conditions. 


\section{Project Title: $\quad$ Remediation of the STF-02 Gun Range \\ Document Type: Construction Specification $\quad$ Project Number: 23368 SPC \\ 646 \\ Revision: 2}

\section{EXCAVATION:}

Description: This work shall consist of authorized excavation of lead contaminated soils and staging of these contaminated soils as indicated in the Statement of Work and shown on the construction drawings.

General Soil Excavation Requirements: In all excavation locations, the Subcontractor shall contain excavation operations within the designated limits. If conditions encountered warrant modification to the designated limits, the Contractor shall be notified prior to work proceeding.

Unauthorized Excavation: Unauthorized excavation consists of removal of materials beyond indicated elevations or dimensions without specific direction by the Contractor.

Unauthorized excavation shall be at the Subcontractor's expense.

\section{Control of Water: The Subcontractor shall furnish, install and operate the equipment}

required to keep surface water contained inside the contaminated soil boundary shown on the drawings by constructing temporary ditches, berms or other appropriate means of control. Water shall be allowed to infiltrate into the soil or used for dust suppression.

Excavation: This activity includes, but is not necessarily limited to mobilization, surveying and marking excavation boundaries, excavation, stockpiling of lead contaminated soil, sieving, incidental dust control, control of storm water and demobilization. Excavations may include mechanical and manual methods. Estimated quantities are shown on the construction drawings.

The lead contaminated soil areas identified in Berm $2 \& 3$ shall be excavated to a minimum depth of 18-inches and the EOCR Leach Pond shall be excavated to a depth of 6-inches or to basalt, whichever occurs first. Testing shall be performed by the Contractor to determine all of the contaminated soils have been removed from the sites. Additional soil removal may be required as directed by the Contractor.

\section{STOCKPILING:}

Stockpiling of Contaminated Materials: One composite surface background sample taken by the Contractor from the stockpile areas prior to construction will document the level of contamination present at the onset of construction. Contamination under stockpile areas resulting from remedial action activities shall be cleaned up to pre-construction levels at the Subcontractor's expense. The following minimum requirements shall be incorporated in the stockpile design.

Cover: A geomembrane (reinforced ultra-violet stabilized polyethylene) cover or an approved stabilization agent shall be used to prevent precipitation from entering a stockpile and volatile emissions and dust from escaping. Control measures such as wetting the 


\section{Project Title: $\quad$ Remediation of the STF-02 Gun Range \\ Document Type: Construction Specification $\quad$ Project Number: 23368 SPC 646 \\ Revision: 2}

1 stockpile surfaces shall be employed to suppress dust. The minimum thickness of the

2 geomembrane cover shall be 10 mils.

Diversion Measures: Berms and/or other suitable diversion measures (such as drainage swale) shall be constructed around the stockpiles to prevent run on and run off.

\section{SIEVING CONTAMINATED SOILS:}

Berm soil identified as contaminated, sand from the Shooting House, and excavated soils from the EOCR Leach Pond shall be sieved through the following screen sizes:

- 3/4" Sieve

- $3 / 8 "$ Sieve

Note: field conditions may require a change of at least one of the above sieve sizes.

Following sieving operations, the material shall be separately stockpiled in the following piles: $+3 / 4$ " material, $3 / 4$ " to $3 / 8$ " material, and $-3 / 8$ " material. Stockpiles will be sampled by the Contractor.

\section{GRADING:}

General: The site shall be cleared of all trash and debris prior to grading. The remaining soil berms shall be graded to approximate the surrounding topography. Disturbed areas shall be backfilled with six inches of topsoil.

Any areas outside the STF-02 remediation area which are damaged or disturbed by the Subcontractor's operations shall be revegetated by the Subcontractor at no cost to the Contractor. Revegetation shall be in accordance with Section 02486 of these specifications.

Placement: All material must be placed in uniform layers not to exceed 8-in. loose measurement and brought up simultaneously. No water shall be used for placing, settling or compacting backfill or fill except to obtain optimum moisture content.

Compaction: Unless otherwise indicated, compact all backfill using 3 to 4 passes by mechanical devices such as rollers, vibratory compactors or mechanical tampers. Each 8-in., maximum, loose measurement lift shall be compacted before the next lift is placed thereon.

\section{LOADING/PACKAGING:}

General: The Subcontractor shall carefully load and package contaminated soils into Contractor supplied containers. Contamination under loading areas resulting from remedial action activities shall be cleaned up to pre-construction levels at the Subcontractor's expense.

DECONTAMINATION: 


\section{Project Title: $\quad$ Remediation of the STF-02 Gun Range \\ Document Type: Construction Specification $\quad$ Project Number: 23368 SPC 646 \\ Revision: 2}

1 The decontamination of all Subcontractor equipment or tools shall be the responsibility of the 2 Subcontractor. Decontamination must occur within the STF-02 remediation area.

3 Decontamination may not be performed at any other areas within the site, or at an off-site 4 facility.

\section{METHOD OF MEASUREMENT:}

Dust Control: Dust control will not be measured for separate payment.

Excavation: Excavation will be measured by the cubic yard.

Sieving: Sieving materials will not be measured for separate payment.

Grading: Grading of the STF-02 remediation area shall be measured by the cubic yard of moved material.

Loading/Packaging: Loading and packaging of contaminated soils and lead fragments will not be measured for separate payment.

\section{BASIS OF PAYMENT:}

Dust Control: No separate payment will be made for dust control. It shall be included in the unit price for excavation.

Excavation: Payment will be made at the contract unit price per ton of material removed. The payment shall be full compensation for all work associated therewith, including but not limited to, surveying of excavation boundaries and topography, excavation of soil and loose surface rock, sieving, loading, incidental dust control, control of storm water, and equipment decontamination.

Sieving: No separate payment will be made for sieving contaminated berm soils, sands from the shoot house, or EOCR pond soils. It shall be included in the unit price for excavation.

Grading: Payment shall be made at the contract unit price per cubic yard of grading of the STF-02 remediation area. The cost shall include removal of debris and vegetation, grading of remaining soil berms, compaction, and hauling/placement/compaction of top soil for revegetation.

Loading/Packaging: No separate payment will be made for the loading/packaging of the contaminated soils and lead fragments. It shall be included in the unit price for excavation.

\section{FIELD QUALITY CONTROL:}

Topographic surveys may be conducted by the Contractor prior to the start and upon completion of the excavation work to verify quantities. The Subcontractor shall provide confirmatory final survey. 
Project Title: $\quad$ Remediation of the STF-02 Gun Range

Document Type: Construction Specification $\quad$ Project Number: 23368

SPC 646

Revision: 2

1

2 The Subcontractor shall be responsible to in-process inspection during execution of all work.

3 Surveillance will be performed by the Contractors Representative to verify compliance of the

4 work to the drawings and specifications.

5

6 END OF SECTION 02200 


\section{Project Title: $\quad$ Remediation of the STF-02 Gun Range \\ Document Type: Construction Specification $\quad$ Project Number: 23368 \\ SPC \\ 646 \\ Revision: 2}

\section{$\underline{\text { SECTION 02486--REVEGETATION }}$}

PART 1--GENERAL

\section{SUMMARY:}

Section Includes, but is not limited to:

Preparing seedbeds, sowing grasses, applying fertilizer, and applying mulch to revegetate disturbed sites.

$\underline{\text { Related Work: }}$

02200 Earthwork

\section{SUBMITTALS:}

Seed Mix Certification: The Subcontractor shall submit seed mix certification for approval by the Contractor 8-days prior to revegetation.

Soil Analysis: The Subcontractor shall submit results of the soil, fertilizer analysis for approval by the Contractor 8-days prior to revegetation.

\section{PART 2--PRODUCTS}

\section{MATERIALS:}

Topsoil: Clean topsoil free from any toxic minerals, noxious weeds or other objectionable material.

Seed and Seedling Mix: The table listed below provide the recommended seeding materials and planting rates for the Security Training Facility Gun Range area.

The seed should be planted using a Truax-type drill with no-till attachment. This planting

35 shall be performed between October 1 and November 30 or February 1 and March 20.

36 Caution should be taken to ensure the seed bed is not too soft for the drill to operate properly

37 resulting in improper seeding depth. After planting, the areas shall be covered with wood

38 chip mulch at a rate of 15-tons/acre. Wood chips will be provided by the Contractor at the

39 job site.

41 The following grass mix shall be used for all disturbed areas:

\begin{tabular}{|lc|}
\hline SPECIES & $\begin{array}{c}\text { RATE OF APPLICATION } \\
\text { (POUNDS PER ACRE PURE } \\
\text { LIVE SEED) }\end{array}$ \\
\hline Green Rabbitbrush & 0.5
\end{tabular}




\section{Project Title: $\quad$ Remediation of the STF-02 Gun Range \\ Document Type: Construction Specification \\ SPC \\ 646 \\ Project Number: 23368 \\ Revision: 2}

\begin{tabular}{ll|}
$\begin{array}{l}\text { (Chrysothamnus viscidiflorus) } \\
\text { Indian Rice Grass "Rimrock" } \\
\text { (Achnatherum hymenoides) }\end{array}$ & 2 \\
$\begin{array}{l}\text { Thickspike wheatgrass "Bannock" } \\
\text { (Elymus lanecolatus ssp. lanceolatus) } \\
\begin{array}{l}\text { Bottlebrush Squirreltail } \\
\text { (Elymus elymoides) }\end{array}\end{array}$ & 2 \\
$\begin{array}{l}\text { Western wheatgrass "Rosanna" } \\
\text { (Pascopyrum smithii) }\end{array}$ & 2 \\
$\begin{array}{l}\text { Bluebunch wheatgrass "Goldar" } \\
\text { (Pseudoroegneria spicata ssp. spicata) }\end{array}$ & 2 \\
$\begin{array}{l}\text { Northern Sweetvetch } \\
\text { (Hedysarum boreale) } \\
\begin{array}{l}\text { Munro globemallow } \\
\text { (Sphaeralcea munroana) }\end{array}\end{array}$ \\
$\quad$ Total
\end{tabular}

1

Possible sources for seed include:

- Cedera Seed Inc., P.O. Box 97, Swan Valley, ID 83449, 208-483-3683 FAX 208483-3684

- Idaho Grimm Growers Warehouse Corp., P.O. Box 276, Blackfoot, ID 83211-0276, 208-785-0830 FAX 208-785-0841

- Granite Seed, 1697 West 2100 North, Lehi, UT, 801-768-3967 FAX 801-768-3967

Fertilizer: The Subcontractor shall perform a soil analysis of the soils disturbed by excavation and also the identified borrow source for topsoil to determine the appropriate fertilizer mix and application rates for successful growth of the specified seed mix. The Subcontractor shall identify to the soil analysis laboratory that revegetation will be with native grasses. All costs associated with the soil analysis and fertilizer requirements shall be included in the subcontract price.

Mulch: Mulch shall be wood chip mulch at a rate of 15-tons/acre. Wood chips will be provided by the Contractor at the job site.

\section{EQUIPMENT:}

Seedbed Preparation: Truax-type drill with no-till attachment, or similar equipment.

Seeding and Fertilizing: Brillion seeder, or other similar equipment.

\section{PART 3--EXECUTION}

Season of Work: Seeding shall be done between October 1 and November 30 or February 1 and March 20. Specific ideal seeding times within these windows shall be as required for 


\section{Project Title: $\quad$ Remediation of the STF-02 Gun Range \\ Document Type: Construction Specification $\quad$ Project Number: 23368 SPC 646 \\ Revision: 2}

proper seedbed preparation. Areas to be seeded shall be maintained reasonable free of weeds. Weeds shall be kept from going to seed.

Seedbed Preparation: Soil shall be tilled a minimum depth of 3-inches. The seedbed shall be firm below seeding depth and well pulverized and loose on top. It shall be free of clods and weeds. Seedbed preparation shall not be performed when soil conditions are not suitable for tilling: too dry, too wet, frozen, etc. Tillage shall produce cross-slope furrows on slopes.

On areas subject to severe erosion, the extent of seedbed preparation shall not exceed that which can be seeded in one day.

Fertilizing: Fertilizing shall closely follow seedbed preparation. Fertilizer shall not be mixed with seed. Fertilizer may be drilled or broadcast. Fertilizer shall be applied at a rate of determined by the soil analysis.

Seeding: Seeding shall closely follow fertilizing. If the seedbed has been disturbed, then the Subcontractor shall prepare the seedbed again. Seeding work shall not proceed until the seedbed has been inspected. Seeds shall be thoroughly mixed prior to application. Seeds shall be uniformly applied at the previously specified rate. Seeds shall be buried 0.25 to 0.75 inches. Seeding shall not be performed when weather conditions are unfavorable: high wind, heavy rain, etc.

Mulching: Mulch shall be spread uniformly at a rate of 15 ton per acre. Mulch shall be applied with no more than one pass of the equipment. Mulching shall not be performed when wind interferes with mulch placement.

Protection: Traffic over seeded area shall be prohibited by the Subcontractor during all work activities performed under this contract.

\section{METHOD OF MEASUREMENT:}

$\underline{\text { Revegetation: }}$ Revegetation will be measured by the acre using field survey.

\section{BASIS OF PAYMENT:}

Revegetation: The accepted quantities of revegetation will be paid for at the contract unit price per acre of revegetated area. This price shall include seedbed preparation, seeding, mulching, and fertilizing.

\section{FIELD QUALITY CONTROL:}

Surveillance will be performed by the Contractor's Representative to verify compliance of the work to the drawings and specifications. 


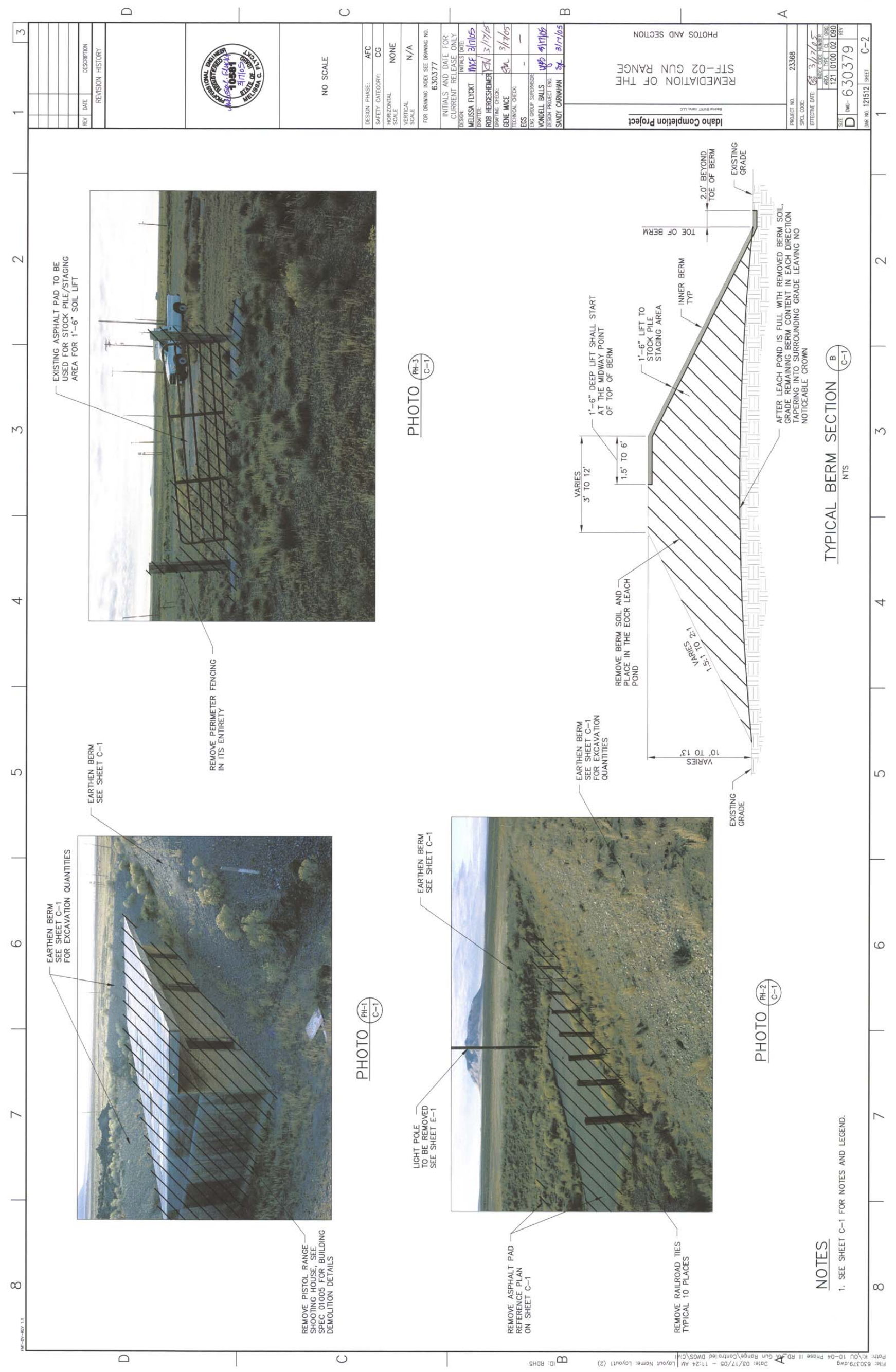




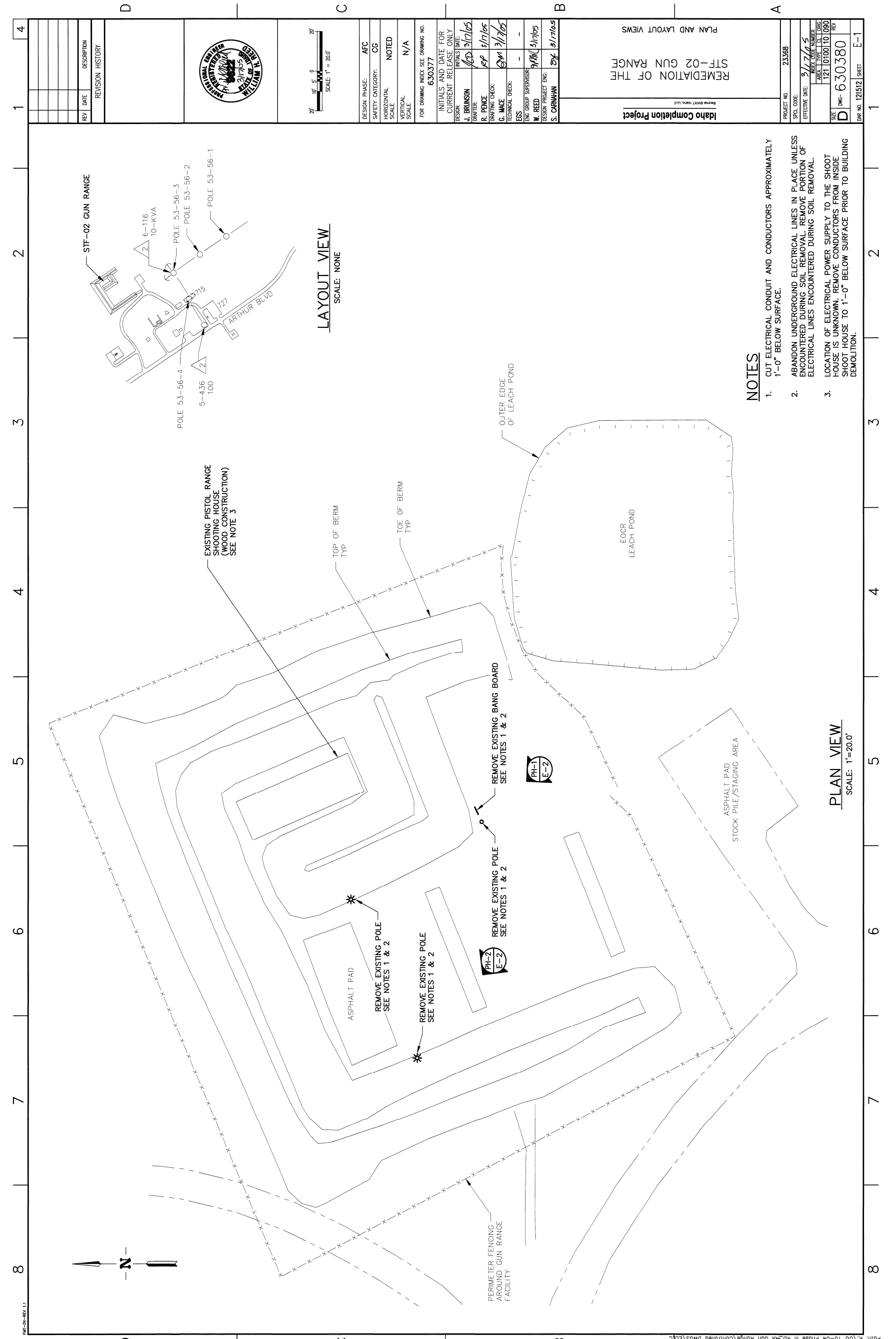




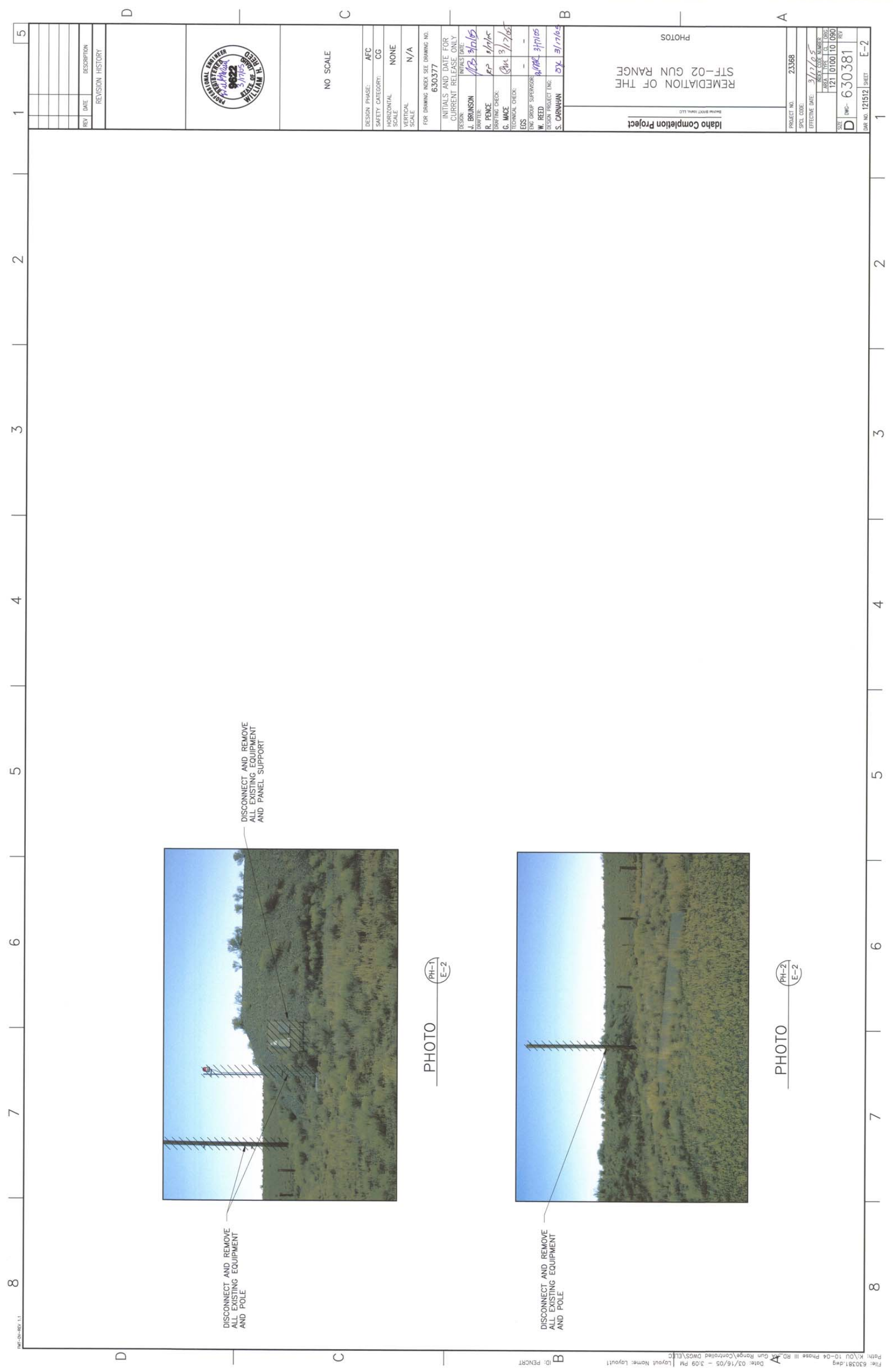

